UNIVERSIDADE DE SÃO PAULO

CENTRO DE ENERGIA NUCLEAR NA AGRICULTURA

ISABELA AMARAL DE CAMARGO

Sistema antioxidante de cana-de-açúcar em resposta à seca

Piracicaba

2013 



\section{ISABELA AMARAL DE CAMARGO}

Sistema antioxidante de cana-de-açúcar em resposta à seca

Versão revisada de acordo com a Resolução CoPGr 6018 de 2011

Dissertação apresentada ao Centro de Energia Nuclear na Agricultura da Universidade de São Paulo para obtenção do título de Mestre em Ciências

Área de Concentração: Biologia na Agricultura e Ambiente

Orientador: Prof. Dr. Antonio Vargas de Oliveira Figueira

Piracicaba 
AUTORIZO A DIVULGAÇÃO TOTAL OU PARCIAL DESTE TRABALHO, POR QUALQUER MEIO CONVENCIONAL OU ELETRÔNICO, PARA FINS DE ESTUDO E PESQUISA, DESDE QUE CITADA A FONTE.

Dados Internacionais de Catalogação na Publicação (CIP)

Seção Técnica de Biblioteca - CENA/USP

Camargo, Isabela Amaral de

Sistema antioxidante de cana-de-açúcar em resposta à seca / Isabela Amaral de Camargo; orientador Antonio Vargas de Oliveira Figueira. - - versão revisada de acordo com a Resolução CoPGr 6018 de 2011. - - Piracicaba, 2013.

85 f.: il.

Dissertação (Mestrado - Programa de Pós-Graduação em Ciências. Área de Concentração: Biologia na Agricultura e no Ambiente) - Centro de Energia Nuclear na Agricultura da Universidade de São Paulo.

1. Antioxidantes 2. Estresse abiótico 3. Expressão gênica 4. Fotoquímica 5. Peroxidase I. Título

CDU $581.13: 633.61$ 
Dedico este trabalho ao meu amado

Pai (in memorian) por ter me deixado

o bem mais precioso... O Estudo!

Sei que NUNCA mediu esforços

em prol da Educação.

Minha eterna gratidão!

Ofereço este trabalho a minha amada Mãe, Irmãos,

Tias, Tios e Namorado pela dedicação, carinho e o imenso apoio sempre. Obrigada por confiarem em mim! 


\section{AGRADECIMENTOS}

A Deus, pela oportunidade de evoluir e por estar comigo em todos os momentos da minha vida;

Ao Prof. Dr. Antonio Figueira pela oportunidade e confiança depositada em mim.

Ao amigo Dr. Renato Ferreira, pelos ensinamentos, paciência, momentos de discussão científica e "estresse severo";

Aos técnicos do Laboratório de Melhoramento de Plantas - CENA/USP: Raquel Orsi, Wlamir Godoy, José Alves, Paulo Cassieri, Inês Possignolo e Felippe Campana por todo apoio na execução dos experimentos e pela amizade;

Aos companheiros do Laboratório de Melhoramnto de Plantas: Aline Harissis, Amanda Almeida, Amanda Betega, Angela Artero, Daniela Bardella, Fabiana Manarelli, Fernando Ferreira, Francisco Claudio Lopes, Gabriela Gaspari, Gabriela Juliano, Gyslayne Bitencourt, Ilse Ferrari, Isabella Possignolo, Letícia Bilato, Lorena Sereno, Melissa Alves, Roberto Camargo, Rodolfo Maniero, Tais Tomazim e Vanessa Voigt pelos momentos prazerosos de convivência. Especialmente agradeço: André Tagliaferro, Luis Henrique Damasceno, Verusca Rossi, Marielle Vitti, Deborah Nishimura, Joni Lima e Eduardo Bressan pelo apoio e conselhos na execução deste trabalho;

As amigas da salinha, Juliana Leles, Layanne Souza, Juliana Deganello, Thaísa Pinheiro e Danielle Scotton pela amizade, incentivos, companheirismo, paciência, apoio sem medir esforços e momentos de prazerosos de convivência;

A Mariana Belloti e João Felipe Nebó pela amizade e suporte durante a execução deste trabalho;

À FAPESP (Fundação de Amparo a Pesquisa do Estado de São Paulo) pela concessão da bolsa e suporte financeiro necessário para a realização deste trabalho;

Aos professores do Centro de Energia Nuclear na Agricultura e da Escola Superior de Agricultura "Luiz de Queiroz" que contribuíram para a minha formação com ensinamentos e conselhos;

Ao Instituto Agronômico de Campinas pela concessão do material vegetal para a realização do estudo, em especial ao Prof. Dr. Rafael Vasconcelos por disponibilizar seu aluno Paulo Marchiori que igualmente agradeço pela contribuição neste trabalho; 
Ao Lucas Souza e Salete Gaziola do Laboratório de Genética Bioquímica de Plantas da ESALQ pelo auxílio sem medir esforços e igualmente agradeço ao Prof. Dr. Ricardo Azevedo por disponibilizar o laboratório para realização de algumas análises;

Ao Prof. Dr. Ricardo Ferraz pelo ensinamento e empréstimo de equipamento e a Karla Vilaça por todo apoio;

A Regina Pecanha pelo suporte durante a análise realizada no Laboratório de Nutrição Animal;

Aos funcionários do Centro de Energia Nuclear na Agricultura (CENA/USP) pelo apoio e compreensão SEMPRE;

Aos meus pais, Celso (in memorian) e Regina, por todo amor, carinho, educação, compreensão e por fazer dos meus sonhos os seus sonhos. Pai e Mãe vocês são únicos, amo vocês;

Aos meus irmãos, Ricardo, André e João Henrique, por sempre estarem presentes em todos os momentos da minha vida, sem medir esforços para me ajudar e me apoiar.

Ao meu namorado, Fernando, pelo amor, paciência, dedicação, ensinamento e por me fazer feliz;

A vocês, pais de coração, Tia Helô, Tia Cely, Tio Luiz e Tio Lycio (in memorian), não existem palavras para o meu eterno agradecimento;

A todos que de maneira direta ou indireta participaram dessa minha conquista...

Deixo aqui meus sinceros agradecimentos! 
"Para todas as grandes coisas exigem-se lutas penosas e um preço muito alto. A única derrota da vida é a fuga diante das dificuldades. O homem que morre lutando é um vencedor."

Pe. Tiago Alberione 


\section{RESUMO}

CAMARGO, I. A. Sistema antioxidante de cana-de-açúcar em resposta à seca. 2013. 85 f. Dissertação (Mestrado) - Centro de Energia Nuclear na Agricultura, Universidade de São Paulo, Piracicaba, 2013.

Cultivares de cana-de-açúcar com tolerância à seca e alta produtividade são desejáveis para a rápida expansão do cultivo da cana-de-açúcar em regiões caracterizadas por um período de déficit hídrico prolongado. Nas plantas, o estresse hídrico induz o dano oxidativo devido ao aumento da produção de espécies reativas de oxigênio (ROS) sem o seu consequente controle. A tolerância à seca pode incluir mecanismos distintos que permitam que as plantas mantenham o metabolismo em níveis normais, exigindo um sistema antioxidante robusto para inativar ROS, o qual consiste de vias enzimáticas, incluindo superóxido dismutase (SOD), catalase (CAT), ascorbato peroxidase (APX), glutationa redutase (GR), glutationa-Stransferase (GST) e glutationa peroxidase (GPX). A elucidação dos mecanismos bioquímicos e moleculares adotados pela cana-de-açúcar em resposta à deficiência hídrica seria relevante para o desenvolvimento de genótipos tolerantes, contribuindo para uma redução na necessidade de água para irrigação. Duas cultivares selecionadas com base em seu comportamento contrastante na resposta à seca foram avaliadas, 'IACSP94-2094' considerada tolerante e 'IACSP97-7065' considerada sensível à seca. O déficit hídrico foi imposto via suspensão da irrigação 4 meses após o plantio em casa de vegetação. A desidratação indicada tanto pelo potencial hídrico da folha quanto pelo conteúdo relativo de água (CRA) corrobora com a redução na assimilação de $\mathrm{CO}_{2}(A)$, condutância estomática $\left(g_{S}\right)$, transpiração $(E)$ em ambas as cultivares. Também foram detectadas, quedas no redimento quântico da fotoquímica do fotossistema II, que comprovam o estabelecimento do déficit hídrico para a cultivar 'IACSP94-2094', corroborado pelas análises de peroxidação lipídica, indicadora da ocorrência do estresse oxidativo. Com relação à atividade específica e expressão gênica das enzimas do sistema antioxidante, foi demonstrado que a superóxido dismutase (SOD), ascorbato peroxidase (APX) e glutationa redutase (GR) são as enzimas chave para o controle do estresse oxidativo desencadeado pela seca na cultivar tolerante. $\mathrm{O}$ perfil das isoformas da SOD revelou que a cultivar tolerante ('IACSP94-2094') possui um maior número de isoformas do que a cultivar sensível ('IACSP97-7065'), sendo a Fe-SOD a mais representativa. Teores de prolina e compostos fenólicos em folhas não mostraram relação direta com resposta ao déficit hídrico para a 'IACSP94-2094', e somente sob máximo défícit hídrico a 'IACSP97-7065' apresentou incrementos no teor de fenólicos, sugerindo que as cultivares podem adotar mecanismos alternativos para superar os efeitos prejudiciais da seca.

Palavras-chave: Atividade enzimática. Cana-de-açúcar. Estresse oxidativo. Seca. Sistema antioxidante. 


\begin{abstract}
CAMARGO, I. A. Antioxidant system of sugarcane to drought response. 2013. 85 f. Dissertação (Mestrado) - Centro de Energia Nuclear na Agricultura, Universidade de São Paulo, Piracicaba, 2013.
\end{abstract}

Sugarcane cultivars with drought tolerance and high yield are highly desirable to the rapid expansion of sugarcane plantings to regions characterized by a period of prolonged water deficit. Water deficit stress in plants induces oxidative damage due to the increase of the production of reactive oxygen species (ROS) without their subsequent control. Drought tolerance may derive from distinct mechanisms that allow plants to maintain metabolism at normal levels, requiring a robust antioxidant system to inactivate ROS, which consists of enzymatic pathways including superoxide dismutase (SOD), catalase (CAT), ascorbate peroxidase (APX), glutathione reductase (GR), glutathione S-transferase (GST) and glutathione peroxidase (GPX). The elucidation of the biochemical and molecular mechanisms adopted by sugarcane in response to water deficit would be relevant to the development of tolerant cultivars, contributing to the reduction in the requirement for irrigation. Two cultivars selected based on their contrasting behavior in response to drought were evaluated, 'IACSP94-2094' selected as tolerant, and 'IACSP97-7065' as more sensitive to drought. Water deficit was imposed by withholding water in plants 4 months after planting in the greenhouse. Water stress was indicated by both leaf water potential and the leaf relative water content (CRA), together by the reduction in $\mathrm{CO}_{2}$ assimilation $(A)$, stomatal conductance $\left(g_{S}\right)$, transpiration $(E)$ in both cultivars. A decrease in quantum yield of photochemistry from photosystem II corroborated the occurrence of water deficit for 'IACSP94-2094', together with results from lipid peroxidation analysis, indicator of oxidative stress. In relation of the specific activity and gene expression of antioxidant enzymes system, it was demonstrated that superoxide dismutase (SOD), ascorbate peroxidase (APX) and glutathione reductase (GR) were the key enzymes controlling oxidative stress triggered by drought in the tolerant cultivar. SOD isoform activity profiles showed that the tolerant cultivar ('IACSP94-2094') displayed more isoforms than the sensitive cultivar ('IACSP97-7065'), with the Fe-SOD being the most representative. Proline and phenolic compound contents in leaves did not show direct relationship with response to drought for 'IACSP94-2094', and only under maximum water deficit 'IACSP97-7065' presented increments in the phenolics content, suggesting that cultivars can adopt alternative mechanisms to overcome the harmful effects of dry.

Keywords: Enzymatic activity. Sugarcane. Oxidative stress. Drought. Antioxidant system. 


\section{SUMÁRIO}

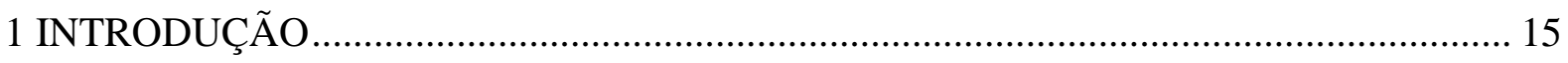

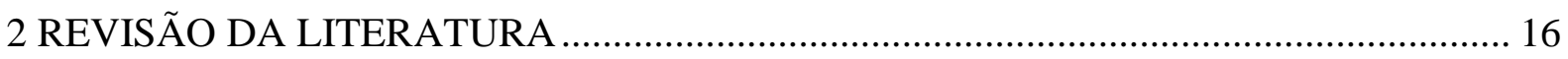

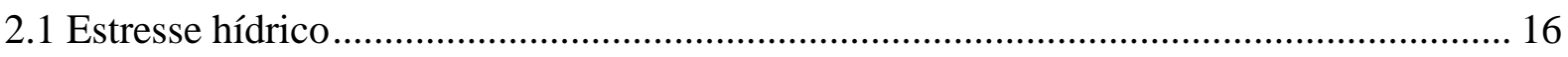

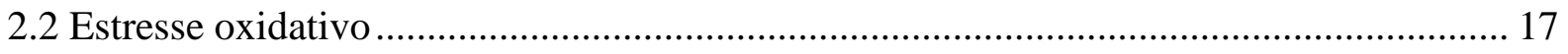

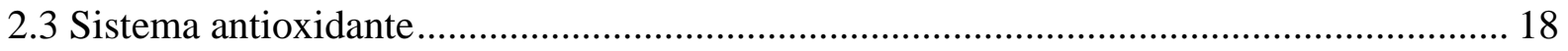

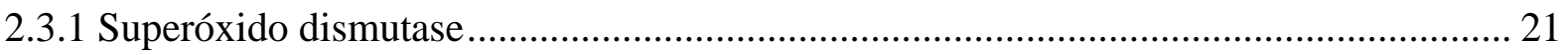

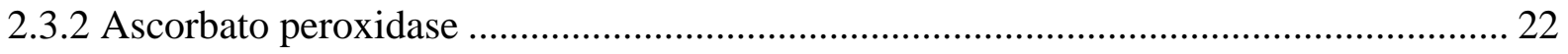

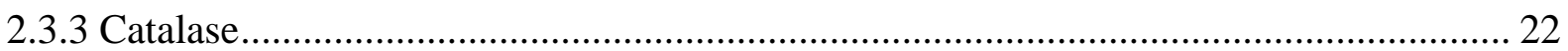

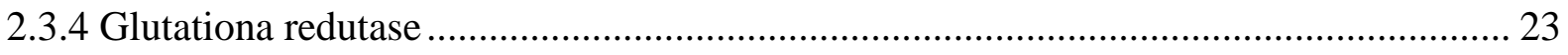

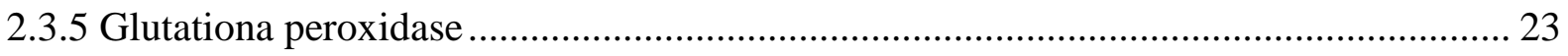

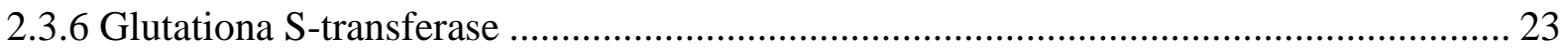

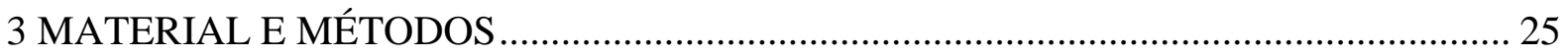

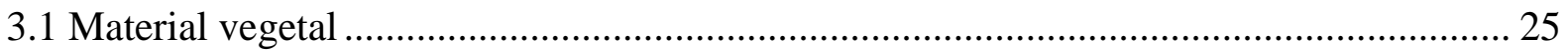

3.2 Imposição de tratamento de déficit hídrico ................................................................. 25

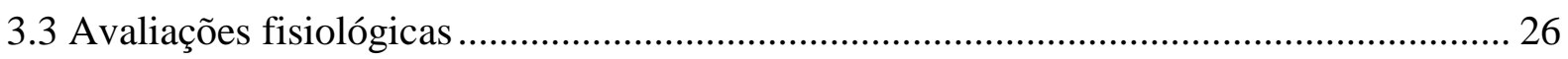

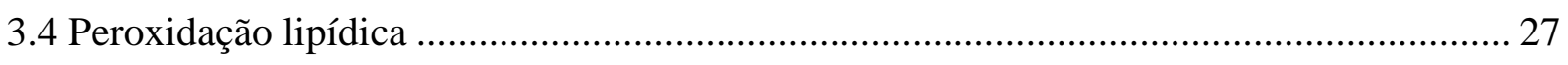

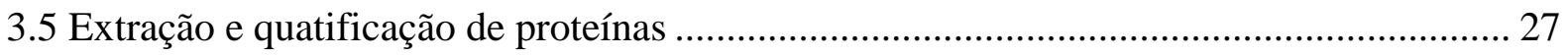

3.6 Eletroforese em gel de poliacrilamida em sistema não desnaturante (PAGE-nativo)....... 28

3.7 Atividade específica da superóxido dismutase (SOD) por espectrofotometria ................. 28

3.7.1 Análise da atividade da SOD em PAGE nativo ............................................................. 28

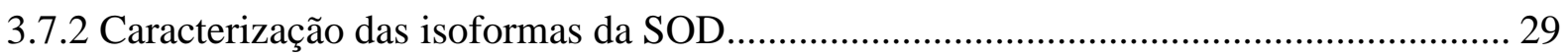

3.8 Atividade específica da ascorbato peroxidase (APX) por espectrofotometria ................. 29

3.9 Atividade específica da catalase (CAT) por espectrofotometria ...................................... 30

3.9.1 Análise da atividade da CAT em PAGE nativo ........................................................ 30

3.10 Atividade específica da glutationa redutase (GR) por espectrofotometria..................... 30

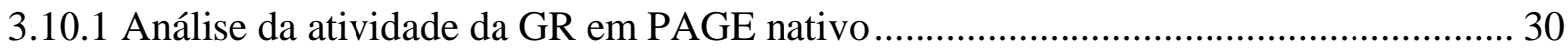

3.11 Extração e determinação da atividade específica da glutationa S-transferase (GST) por

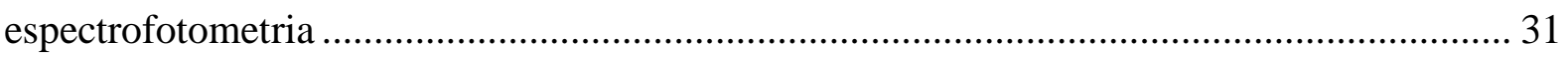

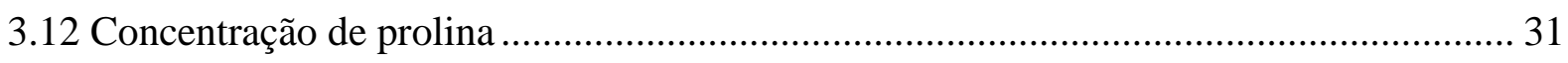

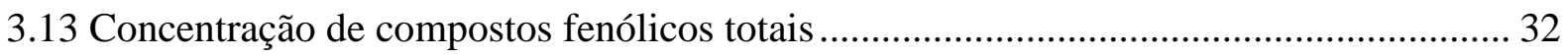

3.14 Identificação de genes associados às enzimas antioxidantes.......................................... 32 
3.15 Iniciadores para genes associados às enzimas antioxidantes ........................................33

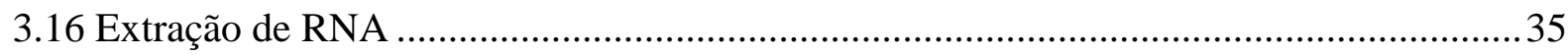

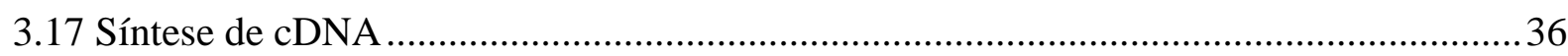

3.18 Análise de amplificação quantitativa de transcritos reversos (RT-qPCR).......................37

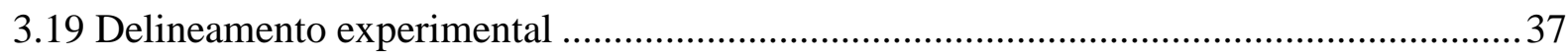

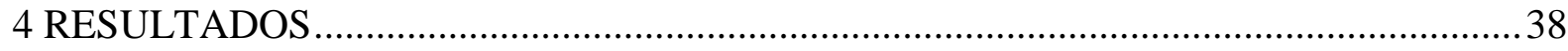

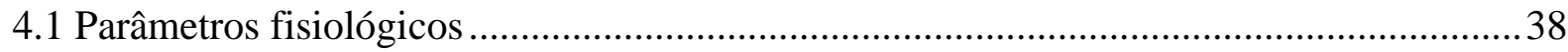

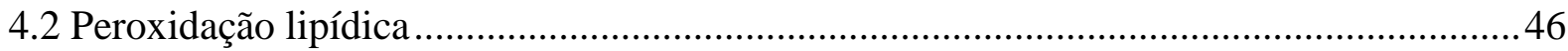

4.3 Atividade específica e expressão gênica das enzimas do sistema antioxidante.................46

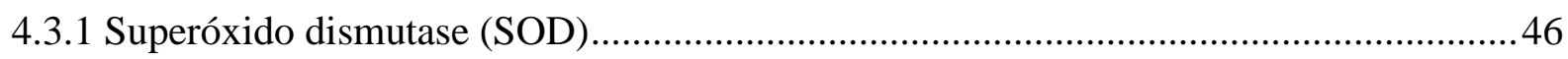

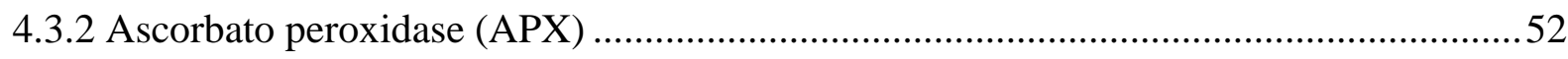

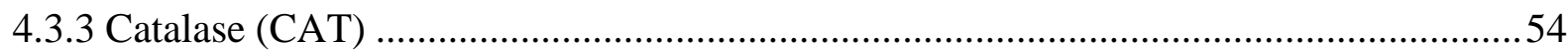

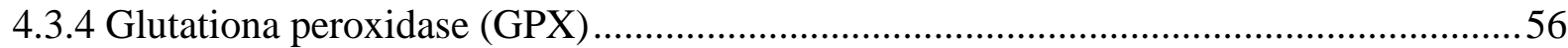

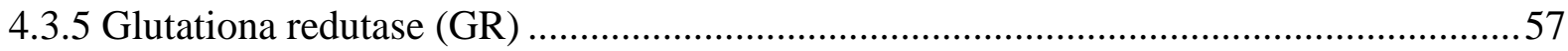

4.3.6 $\gamma$-glutamilcisteína sintetase (GCS) e glutationa sintetase (GS) ...................................60

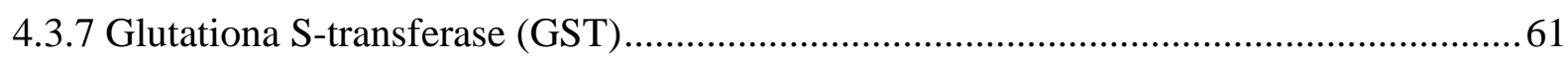

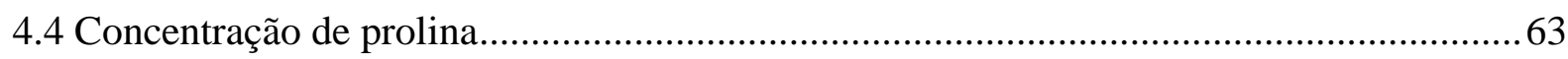

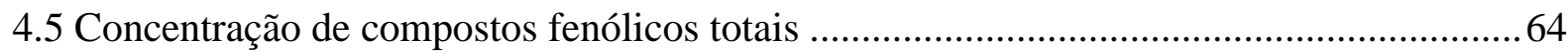

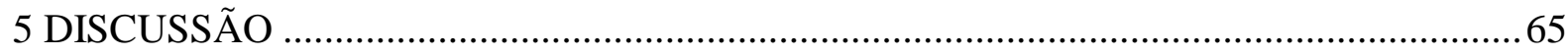

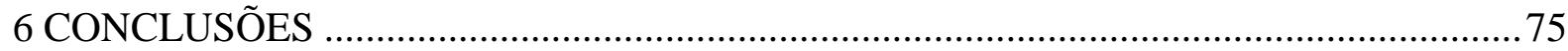

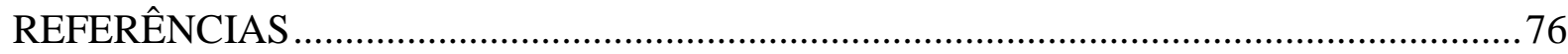




\section{INTRODUÇÃO}

A cana-de-açúcar (Saccharum spp.) é um dos principais produtos agrícolas do Brasil, fonte de matéria-prima para a produção de açúcar e etanol, além da importância dos seus subprodutos como, por exemplo, o bagaço para co-geração de energia, produção de celulose e na alimentação de gado confinado. Para atender tal demanda, o setor sucroalcooleiro deverá apresentar uma expansão da área plantada para regiões predominantemente ocupadas por pastagens, caracterizadas por inverno seco, com períodos acentuados de seca.

A seca é considerada um dos principais estresses abióticos em plantas (CRUZ DE CARVALHO, 2008). A expansão da cultura da cana-de-açúcar para regiões não-tradicionais de cultivo demanda a necessidade do desenvolvimento de cultivares mais adaptadas a ambientes com tendência a ocorrência de seca (CATTIVELLI et al., 2008).

A tolerância à seca consiste em mecanismos que permitem a planta manter o seu metabolismo em níveis normais, devido a alterações fisiológicas e bioquímicas, destacando-se principalmente o ajuste osmótico e a capacidade antioxidante, que resulta da habilidade das plantas em inativar as espécies reativas de oxigênio (ROS) (ANGELOVA; PASHOVA; SLOKOSKA, 2000).

O efeito negativo da ação das ROS recebe o nome de estresse oxidativo, responsável pela ocorrência de danos fotoinibitórios e fotoxidativo em plantas sob condições de seca (ASADA, 1999). A eliminação de ROS ocorre por meio do sistema antioxidante, composto pelas enzimas: superóxido dismutase (SOD), catalase (CAT), ascorbato-peroxidase (APX), glutationa redutase (GR), glutationa peroxidase (GPX), guaiacol peroxidase (GPOX) e glutationa S-transferase (GST) (ASADA, 1999).

Atualmente, pouco se conhece sobre os mecanismos bioquímicos, genéticos e moleculares envolvidos na resposta à seca em cana-de-açúcar, bem como a interação entre eles. Desta forma, a hipótese deste trabalho foi determinar se o sistema antioxidante participa do controle do estresse oxidativo induzido por seca em cana-de-açúcar, e se poderia estar associado a diferenças na tolerância ao déficit hídrico em cultivares contrastantes para resposta a esse estímulo. Diante desta hipótese, este trabalho teve como objetivo avaliar bioquimicamente e molecularmente as enzimas do ciclo ascorbato-glutationa e vias adjacentes auxiliares, a fim de compreender as alterações nos mecanismos de resposta a seca presentes em cana-de-açúcar. 


\section{REVISÃO DA LITERATURA}

\subsection{Estresse hídrico}

O déficit hídrico se estabelece quando a absorção de água pelo sistema radicular não consegue atender a demanda da planta (FAN et al., 2006). Quando há uma queda do potencial hídrico dos tecidos vegetais, várias respostas fisiológicas são induzidas (CATTIVELLI, et al., 2008). Algumas dessas respostas são provocadas pela própria mudança do potencial hídrico, enquanto outras são provocadas por hormônios vegetais (CHAVES; MAROCO; PEREIRA, 2003). Além disso, as respostas celulares variam de acordo com o grau de déficit hídrico (MULLET; WHITSITT, 1996).

À medida que o teor relativo de água e o potencial hídrico diminuem nas folhas, há a indução do fechamento dos estômatos, reduzindo assim a disponibilidade de $\mathrm{CO}_{2}$ e, consequentemente redução na taxa fotossintética (LAWLOR; CORNIC, 2002). Portanto, o fechamento dos estômatos é o principal determinante da redução da fotossíntese (CORNIC, 2000).

A energia luminosa utilizada na fotossíntese é absorvida pela clorofila $a$ e $b$ e carotenóides, que após receberem energia dos fótons podem dissipá-la de três maneiras: dissipação fotoquímica, dissipação não fotoquímica (calor) e fluorescência (TAIZ; ZEIGER, 2009). Sob condições de estresse, pode ocorrer interferência na eficiência quântica potencial do fotossistema II (PSII) e inativação da cadeia transportadora de elétrons que formará ATP e NADPH (KRAUSE; WEISS, 1991). O uso dos parâmetros de fluorescência permite avaliar o efeito do estresse hídrico sobre a fotossíntese, pois a relação inversa entre a fluorescência das clorofilas e a atividade fotossintética pode ser usada para detectar efeitos do estresse, além de detectar danos ao aparato fotossintético (ALLAHVERDIEV; MAVITUNA; GANIEVA, 1998).

As plantas utilizam diferentes tipos de estratégias para enfrentar o estresse hídrico, que consistem em evitar, tolerar e escapar da seca. Evitar é a capacidade da planta em manter o potencial hídrico alto na célula sob estresse, enquanto a tolerância é a capacidade da planta manter suas funções normais, mesmo com potencial hídrico baixo e, escapar da seca, se refere as plantas que completam seu ciclo antes do início da seca (TAIZ; ZEIGER, 2009).

A estratégia de evitar a seca é geralmente obtida por meio de mudanças morfológicas na planta, tais como a redução da condutância estomática, diminuição da área foliar e desenvolvimento de sistemas radiculares profundos (LEVITT, 1980). Por outro lado, a 
tolerância à seca é obtida pela regulação dos mecanismos fisiológicos, bioquímicos e moleculares (REDDY; CHAITANYA; VIVEKANANDAN, 2004). Um exemplo de regulação em condições de estresse é a diminuição da síntese de proteínas e a proteólise acelerada, resultando no acúmulo de aminoácidos, como a prolina (SODEK, 2004). A prolina atua como osmólito, desempenhando a função de osmoregulador por aumentar a capacidade da célula de reter água (DELAUNEY; VERMA, 1993), desempenha também um papel multifuncional no mecanismo de tolerância, atuando na estabilização de estrutura subcelular, eliminação de radicais livres, além de estar relacionada à cascata de sinalização desencadeada pelo estresse (NANJO, 1999).

Entretanto, a resposta das plantas ao estresse depende da sua duração, severidade e frequência, assim como o estádio de desenvolvimento e genótipo (FRITSCHE-NETO; DOVALE; CAVATTE, 2011).

\subsection{Estresse oxidativo}

Fatores abióticos, como a seca, podem atuar de forma prejudicial às plantas, levando a alterações bioquímicas deletérias denominadas de estresse oxidativo, e consequentemente a formação de espécies reativas de oxigênio (ROS) como, o radical superóxido $\left(\mathrm{O}_{2}{ }^{\circ}\right)$, peróxido de hidrogênio $\left(\mathrm{H}_{2} \mathrm{O}_{2}\right)$, radical hidroxila $\left({ }^{\bullet} \mathrm{OH}\right)$ e o oxigênio "singlet" $\left(\mathrm{O}_{2}{ }^{l}\right)$ (SCANDALIOS; ACEVEDO; RUZSA, 2000).

$\mathrm{O}_{2}{ }^{\circ-}$ é formado devido a elétrons desemparelhados (MOLLER, 2001) nas cadeias transportadoras de elétrons das mitocôndrias e dos cloroplastos, onde ocorre também a formação de oxigênio singlet à partir da transferência da energia de excitação da clorofila para o oxigênio (BOWLER; VAN MONTAGU; INZÉ, 1992).

$\mathrm{O} \mathrm{H}_{2} \mathrm{O}_{2}$ é produzido através das reações de fotorrespiração dos peroxissomos ou ainda pode ser produto da $\beta$-oxidação de ácidos graxos (SCANDALIOS, 2005).

$\mathrm{O}{ }^{\bullet} \mathrm{OH}$ tem um grande potencial oxidativo, atacando macromoléculas e levando a danos celulares (SCANDALIOS, 2005), como peroxidação lipídica, desnaturação protéica e mutação no DNA (BOWLER; VAN MONTAGU; INZÉ, 1992), o que pode levar a disfunções metabólicas irreparáveis e até morte celular (SCANDALIOS, 2005). O $\mathrm{O}_{2}{ }^{1}$, formado a partir da transferência da energia de inúmeras ativações para o $\mathrm{O}_{2}$, também produz efeitos deletérios (BOWLER; VAN MONTAGU; INZÉ, 1992). 
Todas as ROS são extremamente reativas e citotóxicas, sendo o ${ }^{\circ} \mathrm{OH}$ e o $\mathrm{O}_{2}{ }^{l}$ tão reativos que suas produções devem ser minimizadas rapidamente. $\mathrm{O} \mathrm{H}_{2} \mathrm{O}_{2}$, por sua vez, quando em altas concentrações na célula pode inibir a fixação de carbono, atuando em enzimas do ciclo de Calvin (SCANDALIOS, 2005). Quando comparado aos demais radicais, o $\mathrm{O}_{2}{ }^{\circ}$ e o $\mathrm{H}_{2} \mathrm{O}_{2}$ são relativamente pouco reativos, mas quando em presença de íons metálicos como o Fe, por exemplo, ativam uma sequência de reações que levam a formação de ${ }^{\circ} \mathrm{OH}$ na reação de Haber-Weiss (BOWLER; VANMONTAGU; INZÉ, 1992). Dessa forma, devido aos efeitos nocivos de altas concentrações de ROS nas células, se faz extremamente importante o equilíbrio entre produção e controle de ROS.

\subsection{Sistema antioxidante}

Como resposta à produção de ROS, os organismos aeróbicos desenvolveram um mecanismo eficiente para a remoção ou mesmo para minimizar os danos causados por eles. Esse mecanismo é denominado sistema antioxidante, podendo ser não enzimático e enzimático. O termo antioxidante descreve qualquer componente capaz de neutralizar as ROS antes da sua conversão a radicais destrutivos.

Os compostos antioxidantes não enzimáticos mais conhecidos são o ascorbato e a glutationa (GSH), mas também inclui flavonóides, alcalóides, compostos fenólicos, aminoácidos não protéicos, tocoferol e carotenóides (GRATÃO et al., 2005). Porém, para a inativação efetiva das ROS é necessária a ação de um sistema antioxidante enzimático que envolve as enzimas superóxido dismutase (SOD), ascorbato peroxidase (APX) e glutationa redutase (GR), moléculas chave do ciclo ascorbato-glutationa. Além dessas, outras enzimas envolvidas em vias adjacentes auxiliares, tais como a catalase (CAT), glutationa peroxidase (GPx) e glutationa S-transferase (GST) também participam do sistema.

No ciclo ascorbato-glutationa (Figura 1), o radical $\mathrm{O}_{2}{ }^{\bullet}$ produzido nos cloroplastos é dismutado a $\mathrm{H}_{2} \mathrm{O}_{2}$ pela superóxido dismutase (SOD), primeira enzima a atuar (AHMAD et al., 2010). Após esta reação, o $\mathrm{H}_{2} \mathrm{O}_{2}$ é primeiramente convertido à água pela ascorbato peroxidase (APX), enzima que tem a maior afinidade pelo substrato (AHMAD et al., 2010). A desintoxicação do $\mathrm{H}_{2} \mathrm{O}_{2}$ pela ascorbato peroxidase (APX) ocorre por meio da oxidação do ascorbato (ASC) a monodehidroascorbato (MDHA), que pode ser regenerado a ascorbato pela monodehidroascorbato redutase (MDHAR) usando o poder redutor de NADPH. Alternativamente, MDHA pode ser espontaneamente convertido a dehidroascorbato (DHA) e, 
assim, o ascorbato é regenerado pela ação da dehidroascorbato redutase (DHAR), utilizando a energia produzida pela oxidação da glutationa reduzida (GSH) em glutationa oxidada (GSSG) (MITTLER, 2002).

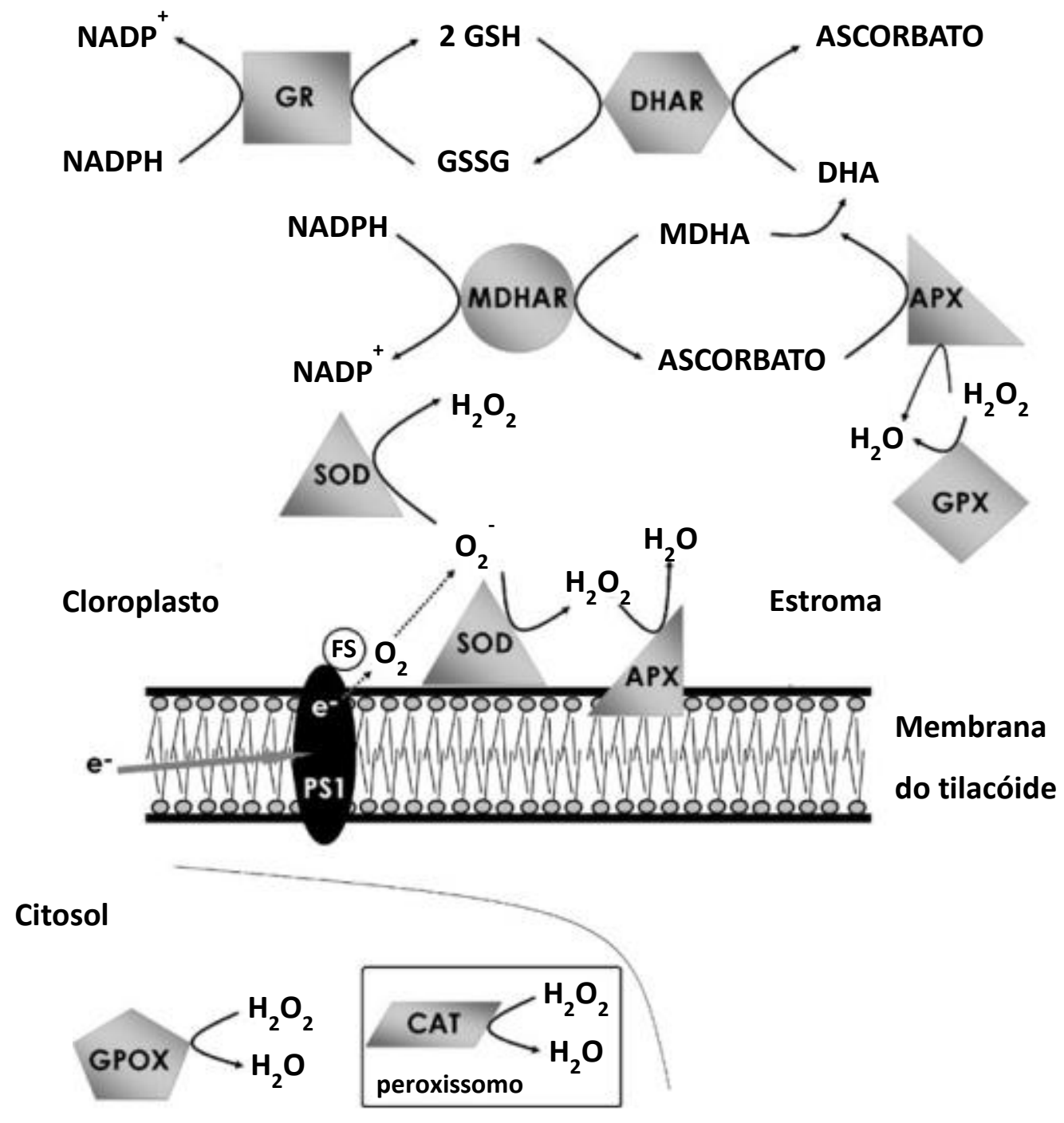

Figura 1 - Ciclo Ascorbato-Glutationa. FS - fator de estroma; PS 1 - Fotossistema I; GR - glutationa redutase: APX - Ascorbato peroxidase; GPX - glutationa peroxidase; SOD - superóxido dismutase; CAT - calatase; GPOX - guaiacol peroxidase; MDHAR - Monodehidroascorbato redutase; DHAR Dehidroascorbato redutase. Adaptado de Azevedo, et al. (2011).

$\mathrm{O}$ excedente de $\mathrm{H}_{2} \mathrm{O}_{2}$ não convertido pela APX pode ser prontamente convertido em água, por enzimas que atuam fora do ciclo ascorbato-glutationa, principalmente a catalase 
(CAT) e a glutationa peroxidase (GPX), entre outras peroxidases (AHMAD et al., 2010). Embora a glutationa peroxidase, pertença a superfamília da glutationa S-transferase, possui atividade de peroxidase (EDWARD et al., 2005).

Ainda no ciclo ascorbato-glutationa, podemos destacar a enzima glutationa redutase (GR), responsável por reciclar poder redutor (NADPH) para a regeneração do ascorbato no ciclo. A GR também mantém os níveis de glutationa reduzida (GSH) (Figura 1), poderoso antioxidante não enzimático sintetizado à partir dos aminoácidos glutamato, cisteína e glicina. Durante a resposta ao estresse, as plantas aumentam a atividade das enzimas que participam da biossíntese de GSH (Figura 2) (FOYER; NOCTOR, 2009). A GSH é substrato da glutationa S-transferase, enzima responsável por desintoxicar as células de xenobióticos, e que conjugada com GSH quebra moléculas tóxicas no vacúolo celular.

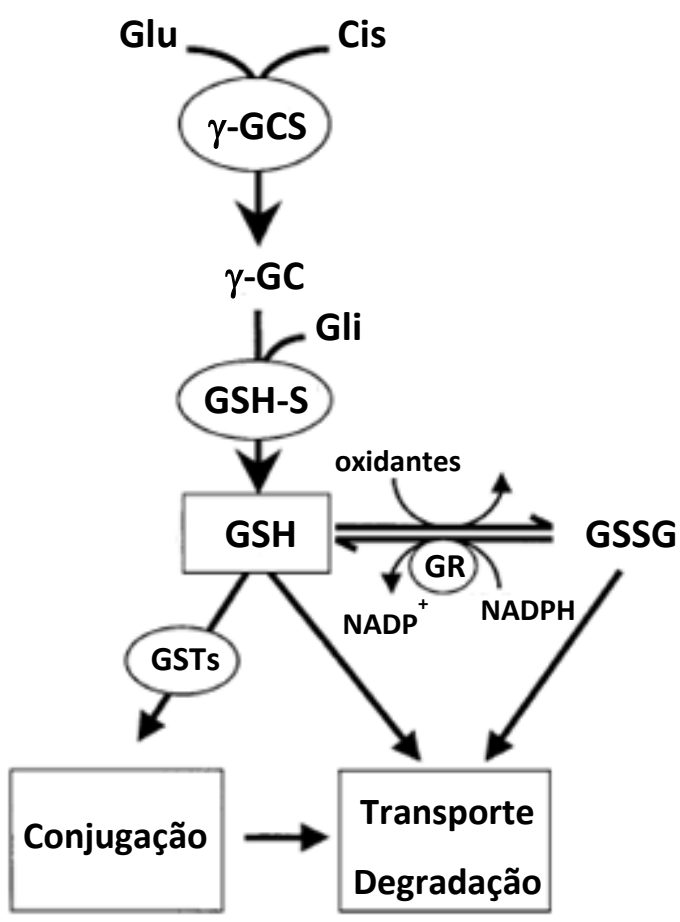

Figura 2 - Biossíntese de glutationa. $\gamma$-GC $-\gamma$-glutamilcisteína; $\gamma$-GCS $-\gamma$-glutamilcisteína sintetase; GR - glutationa redutase; GSH - glutationa reduzida; GSSG - glutationa dissulfeto; GSH-S glutationa sintetase; GST - glutationa S-transferase. Adaptado de Noctor et al. (2002)

O equilíbrio entre as atividades da CAT, SOD e APX é essencial para manter as ROS em níveis aceitáveis e não prejudicar o funcionamento celular. Mecanismos compensatórios são ativados se este balanço for alterado, como no caso da CAT em plantas; se a atividade for 
baixa, outras enzimas responsáveis pela inativação do $\mathrm{H}_{2} \mathrm{O}_{2}$, como a APX, GPX poderão ter suas atividades aumentadas (GRATÃO et al., 2005).

\subsubsection{Superóxido dismutase}

A Superóxido dismutase (SOD; EC 1.15.1.1) foi isolada primeiramente por Mann e Keilin em 1938 a partir de sangue bovino (SCANDALIOS, 2005), sendo encontrada em organismos eucariotos, principalmente em mitocôndrias, cloroplastos e citosol (FERREIRA et al., 2002). A função catalítica da SOD está ligada a cofatores metálicos, que determinam suas isoformas Cu/Zn-SOD, Mn-SOD, Fe-SOD (OLMOS et al., 2003) e Ni-SOD, encontrada em Streptomyces e cianobactéria (BARONDEAU et al., 2004). As várias isoformas da SOD são amplamente distribuídas entre os organismos aeróbicos e os organismos anaeróbicos, aerotolerantes e anaeróbicos obrigatórios (OLMOS et al., 2003).

A SOD é considerada a primeira linha de defesa contra os danos causados pelas ROS, a qual atua dismutando o $\mathrm{O}_{2}{ }^{\circ-}$ a $\mathrm{H}_{2} \mathrm{O}_{2}$ (ALSCHER; ERTURK; HEATH, 2002). Dessa forma, a atividade da SOD interfere na concentração das duas ROS envolvidas na reação de HaberWeiss, fazendo parte do mecanismo central de defesa dos organismos, evitando assim a formação do radical ${ }^{\bullet} \mathrm{OH}$ (LEÓN et al., 2002).

A isoforma $\mathrm{Cu} / \mathrm{Zn}$-SOD é principalmente encontrada no estroma dos cloroplastos e é sensível ao radical cianeto $\left(\mathrm{CN}^{-}\right)$; a $\mathrm{Mn}-\mathrm{SOD}$ e a $\mathrm{Fe}-\mathrm{SOD}$ não são sensíveis ao $\mathrm{CN}^{-}$e são encontradas tanto em células eucarióticas quanto em procarióticas, na matriz mitocondrial (MALLICK; MOHN, 2000). As isoformas Fe-SOD e Cu/Zn-SOD são inativadas pelo $\mathrm{H}_{2} \mathrm{O}_{2}$ (ASADA, 1999).

O número e o tipo de cada isoforma varia entre as espécies vegetais; a $\mathrm{Cu} / \mathrm{Zn}-\mathrm{SOD}$, por exemplo, já foi encontrada em arroz, em mitocôndrias de girassol, em cloroplasto de arabidopsis (CORPAS et al., 1991; PAN; YAU, 1991; KLIEBENSTEIN; MONDE; LAST, 1998), folhas e raízes de soja (FERREIRA et al., 2002) e folhas e calos de cana-de-açúcar (FORNAZIER et al., 2002a; 2002b). A Mn-SOD foi encontrada em mitocôndrias de aveia e feijão (CORPAS et al., 1991; SEHMER; DIZENGREMEL, 1998), folhas e raízes de soja (FERREIRA et al., 2002) e calos de cana-de-açúcar (FORNAZIER et al., 2002b), e a Fe-SOD, rara em plantas, foi encontrada em Arabidopsis (KLIEBENSTEIN; MONDE; LAST, 1998). 


\subsubsection{Ascorbato peroxidase}

A ascorbato peroxidase (APX, EC 1.11.1.11) é responsável pela degradação do $\mathrm{H}_{2} \mathrm{O}_{2}$ utilizando o ascorbato como substrato. Importante na defesa de tecidos fotossintético contra o estresse fotoxidativo, também pode ser encontrada no citosol das células não fotossintetizantes atuando na redução dos níveis de ROS (ASADA, 1992).

A APX, uma heme proteína que ocorre também em mamíferos, é inibida por cianeto, azida, reagentes modificadores de tiol, hidroxiuréia e $\rho$-aminofenol, e seu ciclo catalítico é denominado mecanismo peroxidase "ping-pong", uma vez que na redução do $\mathrm{H}_{2} \mathrm{O}_{2}$, a APX é convertida em composto oxidado com 2 elétrons; formado esse composto, oxida o ascorbato formando o MDHA voltando então a sua forma original (ASADA, 1999).

Quando comparada a CAT, a APX apresenta um $K_{m}$ menor, o que permite a esta enzima um controle mais refinado dos níveis de $\mathrm{H}_{2} \mathrm{O}_{2}$ ou mesmo de sinalização (MITTLER, 2002). São conhecidas 5 isoformas de APX em plantas, as quais foram encontradas no tilacóide, estroma, citosol, peroxissomo e apoplasto (ASADA, 1999).

\subsubsection{Catalase}

A catalase (CAT, EC 1.11.1.6) é uma enzima encontrada principalmente nos peroxissomos, e é responsável pela inativação do $\mathrm{H}_{2} \mathrm{O}_{2}$ formado através da conversão do glicolato a glioxalato, durante a fotorrespiração, sendo o peróxido convertido pela enzima à $\mathrm{H}_{2} \mathrm{O}$ e $\mathrm{O}_{2}$ (IGAMBERDIEV; LEA, 2002). A CAT pode também decompor o peróxido formado durante a $\beta$-oxidação de ácidos graxos nos glioxissomos em tecidos de armazenamento de gordura (HOLTMAN et al., 1994).

A enzima é preferencialmente encontrada nos peroxissomos, mas também pode estar presente em mitocôndrias e no citoplasma (MONTAVON; KUKIC; BORTILIK, 2007). Os cloroplastos não possuem catalase (ASADA, 1999). Em plantas de milho, três isoformas da CAT foram encontradas (SCANDALIOS; ACEVEDO; RUZSA, 2000), mas somente duas foram encontradas em pêssego (BAGNOLI et al., 2004) e cevada (SKADSEN; SCHULZELEFERT; HEBERST, 1995). Em Arabidopsis thaliana, a CAT é codificada por uma família multigênica, formada por três genes $C A T 1, C A T 2$ e $C A T 3$, sendo estes três genes altamente expressos nas inflorescências da planta, porém somente os genes CAT2 e CAT3 são altamente expressos em folhas e ambos são controlados pelo ciclo circadiano (FRUGOLI et al., 1996). 


\subsubsection{Glutationa Redutase}

A glutationa redutase (GR, EC 1.6.4.2) é uma flavoproteína responsável por catalizar a redução da GSSG para GSH, e esta reação é dependente de NADPH. A GR pode ser encontrada tanto em cloroplastos quanto em mitocôndrias, mas sua síntese ocorre no citoplasma da célula de onde é direcionada para as organelas (MULLINEAUX; CREISSEN, 1997). A GR possui ocorrência quase universal, estando distribuída em procariotos e eucariotos, desde bactérias heterotróficas e fotossintetizantes até plantas e animais superiores (FOYER et al., 1997).

A enzima desempenha um papel importante na defesa contra o estresse oxidativo, pois mantém o equilíbrio entre os níveis de GSSG e GSH na célula. A GSH é uma molécula importante dentro do sistema celular, participando inclusive do ciclo ascorbato-glutationa (NOCTOR et al., 2002), ou ainda da síntese de fitoquelatinas (GRATÃO et al., 2005).

\subsubsection{Glutationa peroxidase}

Glutationa peroxidase (GPX, EC 1.11.1.9) é a família que inclui várias isoformas que catalisam a redução de $\mathrm{H}_{2} \mathrm{O}_{2}$ (DIXON et al., 1998). Além da eliminação de $\mathrm{H}_{2} \mathrm{O}_{2}$, as GPXs também servem para desintoxicar produtos de peroxidação lipídica formados devido à atividade de ROS. As GPXs em plantas são classificados em três tipos: GPXs dependentes de selênio (SABEH; WRIGHT; NORTON, 1993), as GPXs hidroperoxidase de fosfolipídios não dependente de selênio (PHGPXs) e glutationa S-transferases (GST), com atividade de glutationa peroxidase (ESHDAT et al., 1997).

As enzimas GPX e GST diferem nas suas subunidades, na ligação de selênio no centro ativo e no seu mecanismo catalítico. A GPX age em conjunto com a glutationa reduzida (GSH), decompondo o $\mathrm{H}_{2} \mathrm{O}_{2}$ em água, enquanto, simultaneamente, oxida GSH. A enzima compete com a Catalase pelo $\mathrm{H}_{2} \mathrm{O}_{2}$ como substrato (AHMAD et al., 2010).

\subsubsection{Glutationa S-Transferase}

A glutationa S-transferase (GST, EC 2.5.1.18) é uma enzima que catalisa a adição de GSH para substratos hidrofóbicos eletrofílicos (DIXON; LAPTHORN; EDWARDS, 2002). É dimérica, encontrada preferencialmente no citoplasma e sua identificação em plantas ocorreu 
devido a sua associação com mecanismos de resistência ao herbicida atrazina em milho (MARRS, 1996). Várias classes de GSTs foram identificadas em plantas respondendo aos mais diversos estresses bióticos ou abióticos, principalmente herbicidas. Em plantas, as GSTs foram classificadas em seis classes, denominadas de Phi (GSTF), Zeta (GSTZ), Tau (GSTU), Theta (GSTT), Lambda (GSTL) e Desidroascorbato redutase (DHARs) (EDWARDS; BRAZIER-HICKS; DIXON, 2005).

A atividade desta enzima leva à desintoxicação dos produtos formados a partir da peroxidação lipídica. Desta forma, as enzimas são ativadas pelo estresse oxidativo provocado pelo $\mathrm{H}_{2} \mathrm{O}_{2}$. Quando atuam na redução de hidroperóxidos, as GSTs são denominadas de glutationas peroxidases (GPX) (EDWARDS; BRAZIER-HICKS; DIXON, 2005). 


\section{MATERIAIS E MÉTODOS}

\subsection{Material vegetal}

Para a realização dos experimentos foram utilizadas plântulas de cana-de-açúcar (Saccharum spp.), cultivadas a partir de mini-toletes, gentilmente cedidas pelo Centro de Cana - Instituto Agronômico (IAC-Ribeirão Preto), sendo 'IACSP94-2094' considerada tolerante (RIBEIRO et al., 2013) a seca e 'IACSP97-7065' sensível (OLIVEIRA, 2012).

Para a realização deste trabalho, foram conduzidos dois experimentos. O primeiro conduzido no período de 21/10/2011 a 18/11/2011 (28 dias) e o segundo, de 13/07/2012 a 23/08/2012 (41 dias). Assim, torna-se importante ressaltar que ambos os experimentos foram realizados criteriosamente da mesma forma, porém os períodos finais de amostragem foram diferenciados, com o aparecimento de déficit hídrico acentuado em períodos distintos.

Os experimentos foram conduzidos em casa de vegetação. Os mini-toletes referentes as duas cultivares foram plantados em bandejas para mudas com 28 células, e 40 DAP (dias após plantio), as plântulas foram transferidas para vasos (40 L) contendo $75 \%$ de substrato Basaplant ${ }^{\circledR}$ e $25 \%$ de areia grossa, sendo quatro plântulas de uma mesma cultivar por vaso. A adubação foi realizada semanalmente pelo período de um mês, utilizando-se $5 \mathrm{~g}$ de adubo químico NPK (10-10-10) adicionado diretamente ao vaso. As plantas foram cultivadas por 4 meses, quando se procedeu a imposição do déficit hídrico.

\subsection{Imposição de tratamento de déficit hídrico}

O déficit hídrico via suspensão total de irrigação foi imposto nas plantas aos 128 DAP em ambas as cultivares, e as amostragens foliares realizadas aos 7, 14, 21 e $28 \mathrm{~d}$ (primavera, $1^{\circ}$ ensaio) e $7,14,21,28$ e $41 \mathrm{~d}$ (inverno, $2^{\circ}$ ensaio). Foram aplicados os seguintes tratamentos: (1) irrigação durante todo o experimento (controle), sendo adicionado $1 \mathrm{~L}$ de água por vaso às 8:00 h; (2) plantas submetidas à seca durante os períodos de $28 \mathrm{~d}$ (primavera) e $41 \mathrm{~d}$ (inverno).

As amostras foliares (folhas +1 ) de ambas as cultivares referentes a cada período experimental foram coletadas e imediatamente congeladas em nitrogênio líquido e estocadas a $-80^{\circ} \mathrm{C}$ até o momento das análises. 


\subsection{Avaliações fisiológicas}

Os parâmetros fisiológicos baseados em trocas gasosas foliares foram avaliados com analisador de gases por radiação infravermelha (IRGA) modelo Li-6400 (Licor, Lincoln, NE, EUA). As medições foram realizadas na primeira folha totalmente expandida e com lígula aparente (folha +1 ), no terço médio do limbo foliar, de acordo com o esquema de numeração de folhas pelo sistema de Kuijper (VAN DILLEWIJN, 1952). As variáveis estudadas foram: assimilação de $\mathrm{CO}_{2}\left(A, \mu \mathrm{mol} \mathrm{m} \mathrm{m}^{-2} \mathrm{~s}^{-1}\right)$, transpiração $\left(E\right.$, mmol $\left.\mathrm{m}^{-2} \mathrm{~s}^{-1}\right)$, condutância estomática $\left(g_{s}\right.$, mol m $\left.\mathrm{m}^{-2} \mathrm{~s}^{-1}\right)$ e concentração intracelular de $\mathrm{CO}_{2}\left(C_{I}, \mu \mathrm{mol} \mathrm{mol}{ }^{-1}\right)$. As avaliações foram realizadas considerando a variação natural da umidade relativa e da temperatura do ar ao longo do experimento.

A fluorescência da clorofila foi medida usando um fluorímetro modulado acoplado (Li-6400-40, Licor Inc, EUA). A fluorescência máxima $\left(F_{m}\right)$ e mínima $\left(F_{o}\right)$ foram monitoradas em folhas adaptadas ao escuro em 30 min e a fluorescência em estado estável $\left(F_{s}\right)$ e máxima $\left(F_{m}{ }^{\prime}\right)$ foram monitoradas em folhas adaptadas a luz (VAN KOOTEN; SNEL, 1990). Assim, a variável fluorescência foi determinada em estado de adaptação ao escuro $\left(F_{v}=F_{m}-F_{o}\right)$ e em estado de adaptação ao claro $\left(F_{v}{ }^{\prime}=F_{m}{ }^{\prime}-F_{s}\right)$, sob $Q=2000 \mu \mathrm{mol} \mathrm{m}{ }^{-2} \mathrm{~s}^{-1}$. A fluorescência mínima após a excitação do fotosistema $I\left(F_{o}{ }^{\prime}\right)$ com luz vermelha distante também foi avaliada. A partir dos valores de $F_{m}, F_{o}, F_{s}, F_{m}$ ' e $F_{o}$ ', foram calculados os seguintes parâmetros: eficiência quântica potencial $\left(F_{v} / F_{m}=\left(F_{m}-F_{o}\right) / F_{m}\right)$ e eficiência quântica efetiva $\left(\Delta F / F_{m}{ }^{\prime}=\left(F_{m}{ }^{\prime}-F_{s}\right) /\left(F_{m}{ }^{\prime}-F_{o}{ }^{\prime}\right)\right)$ do fotosistema II (PSII); taxa de transporte aparente de elétrons $\left(E T R=\Delta F / F_{m}{ }^{*} Q * 0,4 * 0,85\right)$ (EDWARDS; BAKER, 1993). O coeficiente de extinção fotoquímico $(q P)$ foi calculados por $q P=\left(F_{m}{ }^{\prime}-F_{s}\right) /\left(F_{m}{ }^{\prime}-F_{o}{ }^{\prime}\right)($ MAXWELL; JOHNSON, 2000).

O potencial hídrico na folha $(\Psi)$ foi medido as $6 \mathrm{~h}$ da manhã no início de déficit hídrico (5 e 7 d) e máximo (41 d) com uma câmara de pressão Scholander modelo 3005 H07G4P4 (Soilmoisture Equipment Corp, EUA). Já o potencial hídrico do solo ( $\Psi, \mathrm{kPa}$ ) foi monitorado por tensiômetros (Tracom).

O conteúdo relativo de água (CRA) foi determinado de acordo com Barrs e Weatherley (1962). Seguimentos foliares foram coletados e pesados, sendo imediatamente hidratados com água deionizada em um tubo Falcon para turgescência total durante $4 \mathrm{~h}$ sob luz e temperatura ambiente. Após $4 \mathrm{~h}$, as amostras foram retiradas da água e secas com papel de filtro para eliminação da umidade superficial e pesadas imediatamente para obter o peso turgido. As 
amostras então foram secas em estufa a $80{ }^{\circ} \mathrm{C}$ por $24 \mathrm{~h}$ e pesadas para obtenção do peso seco. Cálculo: CRA $(\%)=[($ peso fresco - peso seco $) /($ peso turgido - peso seco $)]$ x 100.

\subsection{Peroxidação lipídica}

A peroxidação lipídica foi determinada pela estimativa do conteúdo de substâncias reativas ao ácido tiobarbitúrico (TBARS), seguindo o método de Buege e Aust (1978), com modificações. Para extração de MDA (malondialdeído), $250 \mathrm{mg}$ de amostras foliares foram maceradas em nitrogênio líquido até formação de um pó homogêneo e foi acrescentado $10 \%$ de PVPP e em seguida, adicionou-se $2 \mathrm{~mL}$ de $0,1 \%$ (p/v) TCA (ácido tricloroacético). Após homogeneização, o extrato foi centrifugado a $10.000 \mathrm{~g}$ a $25^{\circ} \mathrm{C}$ por $5 \mathrm{~min}$. A um volume de $250 \mu \mathrm{L}$ do sobrenadante adicionou-se $1 \mathrm{~mL}$ de solução contendo TCA $20 \%$ (p/v) e TBA (ácido tiobarbitúrico) $0,5 \%(\mathrm{p} / \mathrm{v})$. As amostras foram mantidas por 30 min a $95^{\circ} \mathrm{C} \mathrm{e}$, em seguida, transferidas para banho de gelo por 10 min. Após o resfriamento, as amostras foram centrifugadas a $10.000 \mathrm{~g}$ a $25^{\circ} \mathrm{C}$ por $10 \mathrm{~min}$, com o intuito de separar qualquer resíduo sólido formado durante $\mathrm{o}$ aquecimento nas amostras. As leituras foram realizadas em espectrofotômetro a 535 e $600 \mathrm{~nm}$. A determinação do equivalente da concentração de MDA foi calculada utilizando o coeficiente de extinção molar de $155 \mathrm{mM}^{-1} \mathrm{~cm}^{-1}$. Os resultados foram expressos em nmol de MDA/g de massa fresca (MF).

\subsection{Extração e quantificação de proteínas}

As amostras foliares de cada tratamento foram maceradas em nitrogênio líquido até formação de um pó homogêneo adicionando-se 10\% de PVPP (Polivinil-polipirrolidona), e em seguida, foi adicionado tampão de extração gelado na proporção 1:3 (peso/volume). Foi utilizado o tampão $100 \mathrm{mM}$ fosfato de potássio $\left(\mathrm{pH} 7,5\right.$ ), contendo $\mathrm{K}_{2} \mathrm{HPO}_{4}$ (fosfato de potássio dibásico) e $\mathrm{KH}_{2} \mathrm{PO}_{4}$ (fosfato de potássio monobásico), $3 \mathrm{mM}$ DTT (ditiotreitol) e 1 mM EDTA (ácido etilenodiamino tetra-acético) (FERREIRA et al., 2002). Em seguida, o homogeneizado foi centrifugado a $10.000 \mathrm{~g}$, por $30 \mathrm{~min}$ a $4^{\circ} \mathrm{C}$ e o sobrenadante coletado, alíquotado e estocado em freezer $-80^{\circ} \mathrm{C}$ até o momento das análises.

A concentração de proteína solúvel total foliar foi determinada em espectrofotômetro (Ultrospec 1100 PRO, Amersham Biosciences) a 595 nm, como descrito por Bradford (1976), utilizando-se albumina de soro bovino (BSA) como padrão. 


\subsection{Eletroforese em gel de poliacrilamida em sistema não desnaturante (PAGE-nativo)}

A eletroforese em gel de poliacrilamida (8\%) em condições não desnaturantes foi utilizada para a determinação da atividade específica da superóxido dismutase (SOD), catalase (CAT) e glutationa redutase (GR). Para confecção do gel de resolução foram utilizados $4 \mathrm{~mL}$ de uma solução 40\% acrilamida; $5 \mathrm{~mL}$ tampão 3M Tris-HCl (pH 8,9); $11 \mathrm{~mL}$ água destilada; $38 \mu \mathrm{L}$ TEMED e $50 \mu \mathrm{L}$ persulfato de amônio $10 \%$. O gel de empacotamento foi preparado utilizando-se $1 \mathrm{~mL}$ acrilamida; 2,25 mL solução $500 \mathrm{mM}$ Tris- $\mathrm{HCl}$ (pH 6,7); $5,5 \mathrm{~mL}$ água destilada; $20 \mu \mathrm{L}$ TEMED e $100 \mu \mathrm{L}$ persulfato de amônio $10 \%$. A eletroforese foi realizada a $4{ }^{\circ} \mathrm{C}$ em corrente constante de $30 \mathrm{~mA}$ por gel. O tampão de corrida foi composto por $25 \mathrm{mM}$ Tris (pH 8,3) contendo $192 \mathrm{mM}$ glicina. Concentrações iguais de proteínas foram aplicadas em cada canaleta do gel.

\subsection{Atividade específica da superóxido dismutase (SOD) por espectrofotometria}

A atividade específica da superóxido dismutase foi determinada pelo método espectrofotométrico descrito por Giannopolitis e Ries (1977), com pequenas modificações. A solução de reação com volume final de $3 \mathrm{~mL}$ continha $50 \mathrm{mM}$ tampão fosfato de sódio (pH 7,8); 13 mM metionina; $75 \mu \mathrm{M}$ NBT (nitroazul de tetrazólio); 0,1 mM EDTA; $5 \mu \mathrm{M}$ riboflavina e $50 \mu \mathrm{L}$ extrato protéico. Para a realização do ensaio foram utilizados dois brancos (A e B): o branco A foi incubado sob luz por 5 min juntamente com as amostras, e o branco B sob condição de escuro total. Após a incubação, o branco A adquire coloração roxa intensa, enquanto o branco $\mathrm{B}$ permanece transparente. $\mathrm{O}$ espectrofotômetro foi inicialmente zerado com o branco B e prosseguiu-se a leitura com o branco A e as amostras. O branco A contém formazana total (coloração roxa) que é formada através da reação entre o radical superóxido e o NBT, sendo que, a SOD compete com o NBT pelo radical superóxido deixando a amostra com uma coloração mais clara que a do branco A. A leitura foi realizada em espectrofotômetro a $560 \mathrm{~nm}$ e os resultados foram expressos em U SOD mg-1 proteína total.

\subsubsection{Análise da atividade da SOD em PAGE nativo}

A atividade da SOD foi determinada por eletroforese em gel de poliacrilamida em sistema não desnaturante (PAGE nativo), de acordo com Azevedo et al. (1998). Os geis foram 
lavados em água destilada e incubados no escuro, a temperatura ambiente em solução contendo $100 \mathrm{mM}$ tampão fosfato de potássio (pH 7,8); 1 mM EDTA; 0,1 mM NBT; $3 \%$ TEMED e 0,05 mM riboflavina. Ao final de $30 \mathrm{~min}$, os geis foram colocados em água deionizada e expostos a luz até o aparecimento das bandas. Nestas condições ocorre a fotoxidação do gel, propiciando a formação de uma coloração púrpura, enquanto as bandas correspondentes à atividade de SOD não sofrem reação, promovendo uma revelação negativa. A fotoxidação foi interrompida incubando-se o gel em solução de ácido acético (7\%) por $15 \mathrm{~min}$.

\subsubsection{Caracterização das isoformas da SOD}

A caracterização das isoformas de SOD foi realizada em PAGE nativo. Os géis foram confeccionados como descrito no item 3.6. Ao final da eletroforese, os géis foram divididos verticalmente em três partes, as quais foram distribuídas em $100 \mathrm{mM}$ tampão fosfato de potássio (pH 7,8); $100 \mathrm{mM}$ tampão fosfato de potássio $(\mathrm{pH} \mathrm{7,8)} \mathrm{contendo} 2 \mathrm{mM} \mathrm{KCN}$ (cianeto de potássio) e $1 \mathrm{mM}$ EDTA; $100 \mathrm{mM}$ tampão fosfato de potássio (pH 7,8) contendo $5 \mathrm{mM} \mathrm{H} \mathrm{H}_{2}$ (peróxido de hidrogênio) e $1 \mathrm{mM}$ EDTA. Todos os passos descritos foram realizados no escuro. Após $20 \mathrm{~min}$, os géis foram submetidos a revelação com NBT e riboflavina, como descrito no item 3.6.1. Ao final da revelação, foram analisadas a presença ou ausência de bandas no controle, e nos tratamentos com $\mathrm{KCN} \mathrm{e} \mathrm{H}_{2} \mathrm{O}_{2}$. As isoformas foram então classificadas como Mn-SOD, Fe-SOD ou Cu/Zn-SOD. Mn-SOD é resistente a ambos inibidores ( $\mathrm{KCN}$ e $\mathrm{H}_{2} \mathrm{O}_{2}$ ), Fe-SOD é resistente ao $\mathrm{KCN}$ e inibida por $\mathrm{H}_{2} \mathrm{O}_{2}$ e $\mathrm{Cu} / \mathrm{Zn}$-SOD é inibida por ambos inibidores (AZEVEDO et al., 1998).

\subsection{Atividade específica da ascorbato peroxidase (APX) por espectrofotometria}

A atividade específica da APX foi determinada segundo Nakano e Asada (1981). A reação com volume final de $1 \mathrm{~mL}$ continha $80 \mathrm{mM}$ tampão fosfato de potássio $(\mathrm{pH} 7,0)$; $5 \mathrm{mM}$ de ascorbato; $1 \mathrm{mM}$ EDTA; $1 \mathrm{mM} \mathrm{H}_{2} \mathrm{O}_{2}$ e $50 \mu \mathrm{L}$ de extrato protéico. A atividade de APX foi determinada pelo monitoramento da taxa de oxidação do ascorbato por 1 min a $30^{\circ} \mathrm{C}$, com leitura em espectrofotômetro a $290 \mathrm{~nm}$ e os valores foram expressos em $\mu \mathrm{mol} \mathrm{min} \mathrm{mg}^{-1}$ proteína total. 


\subsection{Atividade específica da catalase (CAT) por espectrofotometria}

A atividade específica da catalase foi determinada pelo método descrito por Ferreira et al. (2002). A reação com volume final de $1 \mathrm{~mL}$ continha $100 \mathrm{mM}$ tampão fosfato de potássio $(\mathrm{pH} 7,5)$ e $\mathrm{H}_{2} \mathrm{O}_{2}$ (peróxido de hidrogênio) solução $30 \%$. A reação foi iniciada pela adição de $25 \mu \mathrm{L}$ de extrato protéico e a atividade determinada pela decomposição de $\mathrm{H}_{2} \mathrm{O}_{2}$ durante 1 min a $25^{\circ} \mathrm{C}$, com leitura em espectrofotômetro a $240 \mathrm{~nm}$. Os resultados foram expressos em $\mu \mathrm{mol} \mathrm{min}^{-1} \mathrm{mg}^{-1}$ proteína total.

\subsubsection{Análise da atividade da CAT em PAGE nativo}

A atividade da CAT foi determinada por eletroforese em gel de poliacrilamida não desnaturante (PAGE nativo) de acordo com Woodbury, Spencer e Stahman (1971). Os géis foram lavados em água destilada e incubados, a temperatura ambiente, em uma solução contendo $0,003 \% \mathrm{H}_{2} \mathrm{O}_{2}$. Ao final de $10 \mathrm{~min}$, os géis foram lavados em água destilada e incubados no escuro, em solução contendo $1 \% \mathrm{FeCl}_{3}$ (cloreto férrico) e $1 \% \mathrm{~K}_{3} \mathrm{Fe}(\mathrm{CN})_{6}$ (ferricianeto de potássio) por 10 min. Após este período os géis foram lavados novamente em água destilada e as reações foram interrompidas incubando-se os géis em solução de ácido acético $(7 \%)$ por 15 min.

\subsection{Atividade específica da glutationa redutase $(\mathrm{GR})$ por espectrofotometria}

A atividade específica da GR foi determinada de acordo com Ferreira et al. (2002). A reação com volume final de 1,75 mL continha $100 \mathrm{mM}$ tampão fosfato de potássio (pH 7,5); 1 mM DTNB (ácido 5,5-ditiobis-2-nitrobenzóico); 1 mM GSSG (glutationa oxidada) e 0,1 mM NADPH (nicotinamida adenina dinucleotídeo de piridina fosfato reduzida). A reação foi iniciada com a adição de $50 \mu \mathrm{L}$ de extrato protéico. A atividade da GR foi estimada pela redução da GSSG por 1 min a $30^{\circ} \mathrm{C}$, com leitura em espectrofotômetro a $412 \mathrm{~nm}$. Os valores

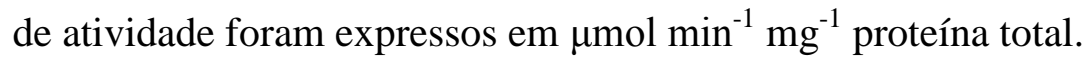

\subsubsection{Análise da atividade da GR em PAGE nativo}

A atividade da GR foi determinada por eletroforese em gel de poliacrilamida não desnaturante (PAGE nativo) de acordo com Lee e Lee (2000). Os géis foram lavados em água 
destilada e incubados no escuro a temperatura ambiente em uma solução contendo $0,25 \mathrm{M}$ Tris (pH 7,5); 0,01 g MTT (brometo de dimetiltiazol-2,5-difeniltetrazólio); 0,01 g DPIP (dicloroindofenol); 3,4 mM GSSG e 0,5 mM NADPH. Ao final de $30 \mathrm{~min}$, os géis foram lavados em água destilada e as reações foram interrompidas incubando-se os geis em solução de ácido acético (7\%) por $15 \mathrm{~min}$.

\subsection{Extração e determinação da atividade específica da glutationa S-transferase (GST) por espectrofotometria}

A extração da GST foi realizada de acordo com Cataneo et al. (2003), com pequenas modificações. As amostras foliares de cada tratamento foram maceradas em nitrogênio líquido até formação de um pó homogêneo adicionando-se 10\% de PVPP. Em seguida, foi adicionado tampão de extração gelado na proporção 1:3 (peso/volume), constituído de $50 \mathrm{mM}$ Tris-HCl (pH 7,5); 1 mM EDTA; 1 mM DTT; $1 \mathrm{mM} \mathrm{GSH;} \mathrm{0,1} \mathrm{mM} \mathrm{Fluoreto} \mathrm{de}$ Fenilmetil-Sulfonil (PMSF); 10\% (v/v) glicerol. Os extratos foram centrifugados a $12.000 \mathrm{~g}$ por 30 min a $4^{\circ} \mathrm{C}$ e os sobrenadantes foram armazenados a $-80^{\circ} \mathrm{C}$ para posterior utilização na determinação da atividade específica da GST e da concentração de proteínas. As concentrações de proteínas nos extratos foram estimadas pelo método de Bradford utilizando BSA como padrão.

A atividade específica da GST foi determinada usando o método descrito por $\mathrm{Wu}$, Omokawa e Hatzios (1996), com pequenas modificações. A reação com volume final de $1 \mathrm{~mL}$ continha 100 mM tampão fosfato de potássio (pH 6,5), 100 mM GSH (glutationa reduzida), $40 \mathrm{mM}$ CDNB (1-cloro-2,4-dinitrobenzeno) e $25 \mu \mathrm{L}$ do extrato protéico. As reações foram conduzidas a $30^{\circ} \mathrm{C}$ por $10 \mathrm{~min}$, com leitura em espectrofotômetro a $340 \mathrm{~nm}$, sendo que nos primeiros 5 min não foi acrescentado à amostra protéica de forma a exaurir a ocorrência de reação espontânea. A taxa de reação específica foi dada pela variação na absorção usando o coeficiente de extinção molar de 9,6 $\mathrm{mM}^{-1} \mathrm{~cm}^{-1}$ para GSH-CDNB (HABIG; JAKOBY, 1981). A quantidade de enzima produzindo $1 \mu \mathrm{mol} \mathrm{min}^{-1}$ é definida como uma unidade de GST.

\subsection{Concentração de prolina}

A determinação da concentração de prolina nas folhas foi realizada de acordo com Bates, Waldren e Teare (1973), com modificações. Para extração de prolina, $300 \mathrm{mg}$ de tecido 
vegetal foram macerados em nitrogênio líquido até a obtenção de um pó fino e homogêneo, ao qual se adicionou $3 \mathrm{~mL}$ de ácido sulfosalicílico 3\% (p/v). Em seguida, o extrato foi centrifugado a $10.000 \mathrm{~g}$ a $25^{\circ} \mathrm{C}$ por $10 \mathrm{~min}$. Coletou-se $1 \mathrm{~mL}$ do sobrenadante, ao qual foi adicionado $1 \mathrm{~mL}$ de ninhidrina ácida (1,25 g de ninhidrina; $30 \mathrm{~mL}$ de ácido acético glacial; $20 \mathrm{~mL}$ de $6 \mathrm{M}$ ácido fosfórico) e $1 \mathrm{~mL}$ de ácido acético glacial. As amostras foram incubadas a $100^{\circ} \mathrm{C}$ por 1 hora e, em seguida, resfriada em banho de gelo por 10 min para parar a reação. Após o resfriamento das amostras, foi acrescentado $3 \mathrm{~mL}$ de tolueno e agitado vigorosamente por vortex, e foi recuperado a fração do tolueno para realização da leitura em espectrofotômetro a $520 \mathrm{~nm}$. A concentração de prolina foi calculada com a curva de calibração feita com solução padrão de L-prolina (Sigma). Os resultados foram expressos em $\mu \mathrm{mol}$ de prolina/g de massa fresca (MF).

\subsection{Concentração de compostos fenólicos totais}

A quantificação de compostos fenólicos foi realizada de acordo com Makkar et al. (1993). Para extração das frações solúveis, $200 \mathrm{mg}$ de amostra moída $(0,25 \mathrm{~mm})$ foi adicionado em becker e acrescentou-se $10 \mathrm{~mL}$ de solução de acetona 70\%. As amostras foram submetidas a ultra-som, em água contendo gelo por $20 \mathrm{~min}$. Após o tratamento, as amostras foram centrifugadas a $3.000 \mathrm{~g}$ por $10 \mathrm{~min} \mathrm{a} 4^{\circ} \mathrm{C}$. O sobrenadante foi coletado e conservado no gelo. Em tubos de ensaio foram adicionados $50 \mu \mathrm{L}$ do extrato; $450 \mu \mathrm{L}$ de água destilada; $250 \mu \mathrm{L}$ do reagente Folin Ciocalteau (1 M) diluído (1 Folin:1 água destilada) e 1,25 mL de $20 \%$ carbonato de sódio. Em seguida, os tubos foram agitados e após 40 min foi realizada a leitura em espectrofotômetro a $725 \mathrm{~nm}$. A concentração de compostos fenólicos foi calculada de acordado com a curva de calibração feita com solução padrão de ácido tânico. Os resultados foram expressos em $\mathrm{g}$ ácido tânico/kg matéria seca.

\subsection{Identificação de genes associados às enzimas antioxidantes}

Foram identificados os genes presumíveis referentes às enzimas antioxidantes superóxido dismutase (SOD), catalase (CAT), glutationa redutase (GR), ascorbato peroxidase (APX) e glutationa peroxidase (GPX), baseado em sequiências de aminoácidos para Oryza Sativa e Arabidopsis thaliana desses genes encontrados no banco de dados do NCBI (National Center for Biotechnology Information, http://www.ncbi.nlm.nih.gov/). As sequências foram identificadas individualmente usando o programa BLAST presente no 
Computational Biology and Functional Genomics Laboratory - Saccharum Gene Index, para cana-de-açúcar (http://compbio.dfci.harvard.edu/cgi-bin/tgi/Blast/index.cgi) para confirmar sua identidade. As sequências completas identificadas foram alinhadas por Clustal W (http://www.genome.jp/tools/clustalw/).

\subsection{Iniciadores para genes associados às enzimas antioxidantes}

Para Glutationa S-Transferase (GST) foram utilizados iniciadores específicos referentes às classes Phi (F) e Tau (U) e dos genes de referência rpl35-4 e UbiQ2 utilizados previamente por Nishimura (2007) (Tabela 1).

Tabela 1 - Descrição dos inciadores desenhados para os genes das enzimas GSTs de cana-deaçúcar e para os genes de referência rpl35-4 e UbiQ2 de acordo com Nishimura (2007)

\begin{tabular}{cccc}
\hline \multirow{2}{*}{ Gene } & \multicolumn{3}{c}{ Iniciadores (5'-3') } \\
\cline { 2 - 4 } & Foward & Reverse & TC n $^{\mathbf{0}}$ \\
\hline ScGSTF3 & TGGGAAGAAAGAAGGTGGTG & GCAAATGCAAGCTGGAAGA & TC34616 \\
ScGSTF4 & CCGCCTGAGTTGACCTTTC & CCATGCTCTTCACACAACCA & TC56926 \\
ScGSTU13 & GCGGAGAAGGTGAAGGAGA & CGAACCAGAACAAGAAGGAGC & TC37214 \\
ScGSTU17 & AGGACCTCGCCAACAAGA & TGAAGATCGGGTACAGAGCA & TC42309 \\
$\boldsymbol{r p l 3 5 - 4}$ & CTGAAGACGGAGAGGGAAAA & GGCGAAGAGAAACTAACAC & TC57186 \\
UbiQ2 & CTTCTTCTGTCCCTCCGATG & TCCAACCAAACTGCTGCTC & TC56667 \\
\hline
\end{tabular}

Além disso, também foram utilizados iniciadores específicos para as enzimas ascorbato peroxidase (APX), catalase (CAT), superóxido dismutase (SOD), $\gamma$-glutamilcisteína sintetase (GCS) e glutationa sintetase (GS) desenhados e utilizados previamente por Rossi (2011) (Tabela 2). 
Tabela 2 - Descrição dos iniciadores desenhados para os genes das enzimas antioxidantes de cana-de-açúcar, com as respectivas siglas dos genes, sequência dos iniciadores e número de acesso (TC - tentative consensus) no banco de dados de Saccharum Gene Index de acordo com Rossi (2011 - dados não publicados*)

\begin{tabular}{cccc}
\hline \multirow{2}{*}{ Gene } & \multicolumn{3}{c}{ Iniciadores (5'-3') } \\
\cline { 2 - 4 } & ACCTGATGTCCCCTTCCAC & CCTCAAACCCAGACCTATCCT & TC114512 \\
\hline SoAPX1 & TC nerse \\
SoAPX3 & TGCCAGGAACAAACTCAACA & AGCCTATCAAAGCCAAGAACC & TC134161 \\
SoAPX4 & GCTGACTGAAGCCAAAAAGG & CAATGGCCGTGTCAAGAA & TC124628 \\
SoCAT2.1 & CCAAGACGCACATACAGGAG & CGTCGAAGAGGAAGCTGAA & TC112764 \\
SoCAT3.1 & CCCACTCAACTACAGGCACA & TCAAGCAAGCATTTCACACC & TC113965 \\
SoGCS & GGCTGCTGTACGATGAGGA & TGGTGTCTTCAAACCAGTCAA & TC131953 \\
SoGS & ATGCTCCATTCTCCCTGCT & ATCAACCTGCCTTGTTTTGG & TC142032 \\
SoSOD1.1 & ATGGGTGTGGTTAGCTTTGG & CCTTCCAGATGTTGTTCAGGT & TC137332 \\
\hline
\end{tabular}

*De acordo com Rossi, V. S. Expressão gênica de enzimas envolvidas na desintoxicação de herbicidas em cana-de-açúcar. Projeto de iniciação científica (FAPESP 2010/17521-5). Centro de Energia Nuclear na Agricultura, Universidade de São Paulo, 2011.

Além dos iniciadores já descritos, foram desenhados para este trabalho outros específicos para outras isoformas das enzimas APX, CAT, SOD, GR e GPX (Tabela 3). Desta forma, foi caracterizada a expressão gênica das enzimas do sistema antioxidante de forma mais completa. Para isso, foram empregadas as sequências completas dos genes identificados no Computational Biology and Functional Genomics Laboratory em estudo na geração de sequências de oligonucleotídeos através do software Primer3 (http://frodo.wi.mit.edu/), designando-se a temperatura de dissociação $(\mathrm{Tm})$ entre 60 a $62^{\circ} \mathrm{C}$, tamanho de amplicons entre 90 a 200 pb, conteúdo de GC (\%) entre 40 a 60 e o tamanho do primer entre 18 a 22 pb.

O par de iniciadores de cada gene foi testado no software NetPrimer (http://www.premierbiosoft.com/netprimer/netprlaunch/netprlaunch.html) para estabilidade, Tm, conteúdo de GC (\%) e interações entre iniciadores.

$\mathrm{Na}$ Tabela 3 se encontra o gene referência $25 S$ rRNA1, segundo Iskandar et al. (2004). 
Tabela 3 - Descrição dos iniciadores desenhados para os genes das enzimas antioxidantes de cana-de-açúcar, com as respectivas siglas dos genes, seqüência dos iniciadores e número de acesso (TC - tentative consensus) no banco de dados de Saccharum Gene Index

\begin{tabular}{|c|c|c|c|}
\hline \multirow{2}{*}{ Gene } & \multicolumn{2}{|c|}{ Iniciadores (5'-3') } & \multirow[b]{2}{*}{ TC no } \\
\hline & Foward & Reverse & \\
\hline SoCAT1.1 & TCAAGCCCAACCCGAAGT & CGAAGAGGAAGAAGAAGGTGTG & TC124662 \\
\hline SoAPX2.1 & AAGTCTTTGGCAAGCAGATGG & TCACTTGGGAGCTGAAGAAGG & TC153064 \\
\hline SoSOD1.2 & TGTCAAGGGCACCATCTTCT & GGCGGTTCTCATCTTCTGG & TC139550 \\
\hline SoSOD2.1.1 & CAAGGGCACGTCCGAGG & CAAACTCGTGGAGGTGGAAG & TC119667 \\
\hline SoSOD3 & GCCCCATTTTAACCCTCACA & GGACAACAACTGCCCTTCC & TC120658 \\
\hline SoGR1 & ACATGGTGGGACGTGTGTG & ACACCGGCATTGGTAAGGA & TC120965 \\
\hline SoGR2 & CGGAGATGTTCCTTGTGCTG & TGGGTTGAATGATGAGGTGAA & TC133244 \\
\hline SoGR3 & GCAATGAACCTACCAAACCAGA & CAAAGGCATCAACATCACCA & TC143489 \\
\hline SoGPX1 & TCACCGTCAAGGATGCTAGTG & GAACTGGTTGCATGGGAAAG & TC136787 \\
\hline SoGPX2 & TTGCATCTCAGTGTGGCTTG & TGCATGGGAAAGCAAGGATT & CA251651 \\
\hline SoGPX4.1 & GGTAAGGACACGGACCATCA & ТТСТССССАСТСТТСТСТССА & CA072038 \\
\hline $25 S$ rRNA1 & ATAACCGCATCAGGTCTCCAAG & CCTCAGAGCCAATCCTTTTCC & CO373883 \\
\hline
\end{tabular}

\subsection{Extração de RNA}

O RNA total foi extraído a partir de amostras foliares de plantas submetidas aos tratamentos utilizando-se o método de precipitação em cloreto de lítio, como descrito por Leal, Albuquerque e Figueira (2007), com pequenas modificações.

Para extração de RNA, $250 \mathrm{mg}$ de tecido foram macerados em nitrogênio liquido até formação de um pó fino e homogêneo, foi acrescentado $10 \%$ de PVPP e em seguida, adicionou-se $1 \mathrm{~mL}$ do tampão de extração contendo $2 \%$ CTAB (brometo de cetiltrimetilamônio); 100 mM Tris- $\mathrm{HCl}$ (pH 8,0); 25 mM EDTA; 2 mM NaCl (cloreto de sódio); $2 \%$ PVP e $2 \%$-mercaptoetanol, pré-aquecido durante 5 min em banho-maria a $65^{\circ} \mathrm{C}$.

Após a adição do tampão de extração, as amostras foram misturadas em vortex e submetidas a $65^{\circ} \mathrm{C}$ por $10 \mathrm{~min}$, e em seguida levadas ao gelo por $1 \mathrm{~min}$. Adicionou-se $1 \mathrm{~mL}$ de CIA (clorofórmio:álcool isoamílico; 24:1 v/v), e após misturar por agitação, as amostras foram centrifugadas a $10.000 \mathrm{~g}$ por $10 \mathrm{~min}$ a $4^{\circ} \mathrm{C}$. O sobrenadante foi transferido para outro tubo, e a este foi adicionado mais $1 \mathrm{~mL}$ de CIA $(24: 1 \mathrm{v} / \mathrm{v})$.

As amostras foram novamente centrifugadas nas mesmas condições anteriores e a fase aquosa superior foi transferida para um novo tubo, centrifugada novamente a $4^{\circ} \mathrm{C}$ para 
precipitação de qualquer eventual contaminante que tenha restado, e se adicionou volume equivalente a $0,25 \mathrm{x}$ do volume restante no tubo de solução $10 \mathrm{M} \mathrm{LiCl}$. As amostras foram deixadas a $4^{\circ} \mathrm{C}$ por $17 \mathrm{~h}$ (over night), e após este período centrifugadas a $10.000 \mathrm{~g}$ por $30 \mathrm{~min}$ a $4^{\circ} \mathrm{C}$.

O sobrenadante foi descartado e o pellet foi lavado por duas vezes com $0,5 \mathrm{~mL}$ de etanol $75 \%$, centrifugado a $10.000 \mathrm{~g}$ por $10 \mathrm{~min}$ a $4{ }^{\circ} \mathrm{C}$, e seco a temperatura ambiente. Após 20 min, o RNA foi ressuspendido em $20 \mu \mathrm{L}$ de água $0,01 \%$ DEPC autoclavada. O RNA foi quantificado através do espectrofotômetro Nanodrop 2000 (Thermo Scientific) e sua integridade foi confirmada via eletroforese.

\subsection{Síntese de cDNA}

Depois da quantificação, cerca de $2 \mu \mathrm{g}$ do RNA extraído de cada amostra foi submetido a tratamento com a enzima DNAse I (Fermentas Life Sciences). Para tanto,

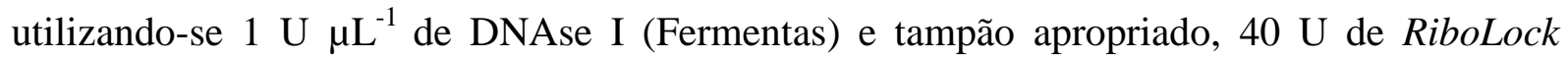
RNAse Inhibitor (Fermentas) e água 0,01\% DEPC para um volume final da reação de $20 \mu \mathrm{L}$. O tubo foi incubado no termociclador GeneAmp PCR System 9700 (Applied Biosystems) a $37^{\circ} \mathrm{C}$ por $40 \mathrm{~min}$. Em seguida, foi adicionado $2 \mu \mathrm{L}$ de $25 \mathrm{mM}$ EDTA, incubado $65^{\circ} \mathrm{C}$ por 10 min e a $4^{\circ} \mathrm{C}$ para a inativação da enzima.

Para a síntese da fita de cDNA foi utilizado $10 \mu \mathrm{L}$ de RNA total tratado com DNAse, e adicionou-se $50 \mu \mathrm{M}$ do iniciador poli-T (oligo-dT, 18pb), $10 \mathrm{mM}$ dNTP e água 0,01\% DEPC em um volume final de $15 \mu \mathrm{L}$, foi incubado a $65^{\circ} \mathrm{C}$ por 5 min e resfriado a $4^{\circ} \mathrm{C}$. A transcrição reversa foi realizada em reação com volume final de $20 \mu \mathrm{L}$ contendo $200 \mathrm{U}$ da enzima RevertAid Premium Reverse Transcriptase (Fermentas) e o tampão da enzima 5X RT Buffer (Fermentas), incubada a $60^{\circ} \mathrm{C}$ por $30 \mathrm{~min}$, sendo a reação finalizada a $85^{\circ} \mathrm{C}$ por 5 min para inativação da enzima.

A reação de transcrição reversa foi realizada no termociclador Applied Biosystems (Modelo Veriti) nas seguintes condições de termociclagem: $25^{\circ} \mathrm{C}$ por $5 \mathrm{~min}, 42^{\circ} \mathrm{C}$ por $60 \mathrm{~min}$ e $70^{\circ} \mathrm{C}$ por $15 \mathrm{~min}$; depois armazenada a $-20^{\circ} \mathrm{C}$. 


\subsection{Análise de amplificação quantitativa de transcritos reversos (RT-qPCR)}

As análises de amplificação quantitativa de transcritos reversos (RT-qPCR) foram realizadas no Rotor Gene Q (Qiagen), utilizando reações contendo $5 \mu \mathrm{L}$ de Platinum SYBR green qPCR SuperMix-UDG (Invitrogen), $10 \mu \mathrm{M}$ de cada iniciador (Tabelas 1,2 e 3), $1 \mu \mathrm{L}$ do cDNA 1:10 (v:v) e água ultrapura (Milli-Q) estéril, num volume final de $10 \mu \mathrm{L}$, sendo que foram analisadas três repetições biológicas para cada condição e genótipo testados, e de cada repetição biológica foram feitas duas replicatas técnicas.

As amplificações foram conduzidas com incubação inicial a $50^{\circ} \mathrm{C}$ por 2 min e $95^{\circ} \mathrm{C}$ por 2 min, seguidos de 40 ciclos de três passos: $95^{\circ} \mathrm{C}$ por $15 \mathrm{~s}, 61^{\circ} \mathrm{C}$ por $25 \mathrm{~s} \mathrm{e} 72^{\circ} \mathrm{C}$ por $30 \mathrm{~s}$, com detecção do sinal da fluorescência ao final de cada etapa de extensão. Após o término dos ciclos de reações, foram determinadas as curvas de dissociação de cada produto amplificado entre $72^{\circ} \mathrm{C}$ e $95^{\circ} \mathrm{C}$ (curva de melting). Os experimentos incluíram controle negativo (sem cDNA) e a eficiência de amplificação de cada par de primers foi determinada pela curva padrão composta de triplicatas das diluições seriais $(1,1 / 4,1 / 16)$.

A aquisição dos dados em tempo real foi efetuada com o programa Rotor-Gene $Q$ Real-Time Analysis 6.0 (Qiagen) que ofereceu os valore dos $\mathrm{C}_{\mathrm{Q}}$ (cycle quantification) utilizados para determinar a diferença da expressão gênica entre os tratamentos.

Para a normalização dos valores de expressão para cada uma das amostras analisadas, calculou-se a variação quantitativa de expressão dos genes de interesse de forma relativa aos genes de referência rpl35-4, UbiQ-2 e rRNA1 (Tabelas 1, 2 e 3 ) com o auxílio do programa Relative Expression Software Tool (REST-384), de autoria de Pfaffl; Horgan e Dempfle (2002) disponível em http://www.gene-quantification.com/rest.html. A utilização deste programa permitiu uma estimativa de expressão gênica com o nível de significância dos genes alvo em relação aos genes de referência.

\subsection{Delineamento experimental}

O delineamento experimental foi inteiramente casualizado e cada tratamento com três repetições, cada repetição sendo uma planta. Os resultados foram expressos como média e erro padrão da média. 


\section{RESULTADOS}

\subsection{Parâmetros fisiológicos}

Para o desenvolvimento deste trabalho foi realizado experimento utilizando-se duas cultivares de cana-de-açúcar contrastante para a resposta à seca: 'IACSP94-2094'(tolerante) e 'IACSP97-7065' (sensível). No primeiro experimento, quando cultivadas em condições de déficit hídrico foi possível observar diferenças visuais drásticas entre os tratamentos, controle e seca, referente à presença de folhas verdes e folhas senescentes, e diferença entre o comportamento das cultivares no que diz respeito à altura das plantas (Figuras 3 e 4), sendo aparentemente a cultivar 'IACSP97-7065' menos afetada pelo déficit hídrico.

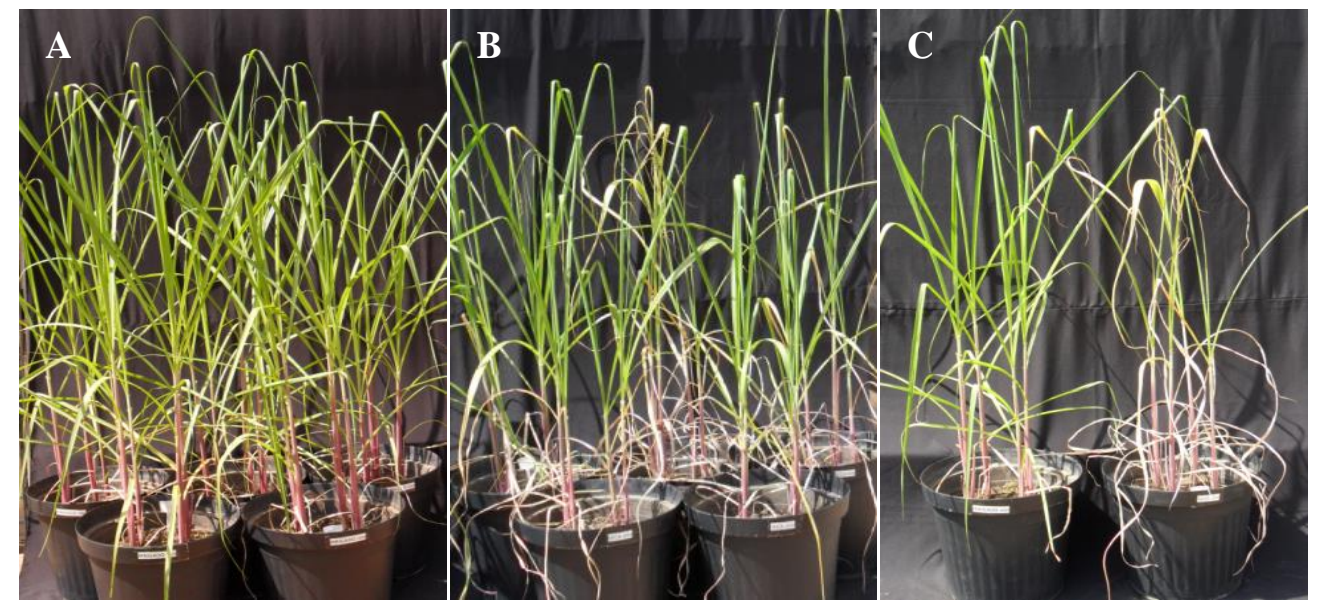

Figura 3 - Cultivar 'IACSP94-2094' aos 28 dias após a imposição dos tratamentos ( $1^{\circ}$ experimento). (A) Plantas controle irrigadas; (B) Plantas submetidas à seca; (C) Vaso controle irrigado (esquerda) e vaso sob seca (direita)

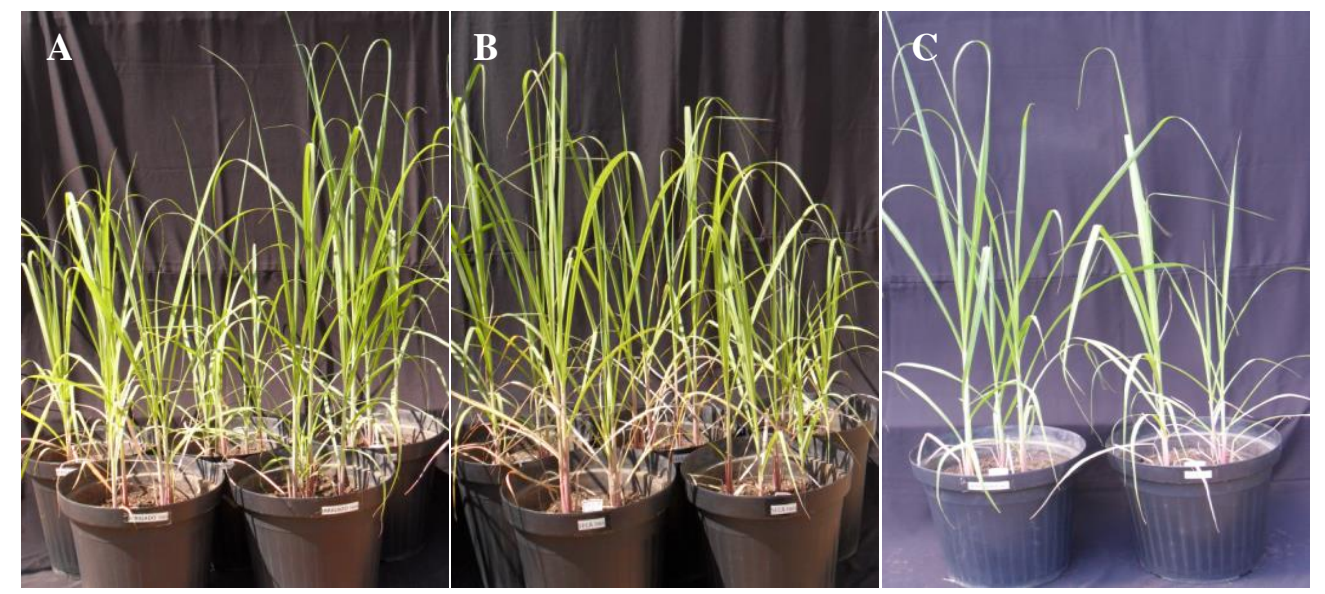

Figura 4 - Cultivar 'IACSP97-7065' aos 28 dias após a imposição dos tratamentos ( $1^{\circ}$ experimnto). (A) Plantas controle irrigadas; (B) Plantas submetidas à seca; (C) Vaso controle irrigado (esquerda) e vaso sob seca (direita) 
Para determinação do déficit hídrico, as cultivares foram avaliadas quanto a assimilação de $\mathrm{CO}_{2}(A)$ e condutância estomática $\left(g_{S}\right)$ ao longo do período experimental, sendo que, o período de máximo déficit hídrico ocorreu 28 dias após a imposição dos tratamentos.

Foi observada redução na assimilação de $\mathrm{CO}_{2}(A)$ e na condutância estomática $\left(g_{S}\right)$ na cultivar tolerante ('IACSP94-2094'), sendo mais pronunciada aos 28 dias após tratamento (DAT) (Figura 5 A, C). Para a cultivar sensível ('IACSP97-7065'), surpreendentemente não foram observadas diferenças nos valores absolutos de assimilação de $\mathrm{CO}_{2}$ e na condutância estomática $\left(g_{S}\right)$ nas plantas sob estresse hídrico ao longo do tratamento, entretanto, quando comparadas as plantas controles, as quais tiveram aumento na taxa fotossintética e na condutância estomática a partir de 21 DAT, é possível observar uma diferença acentuada nesses parâmetros (Figura 5 B, D).
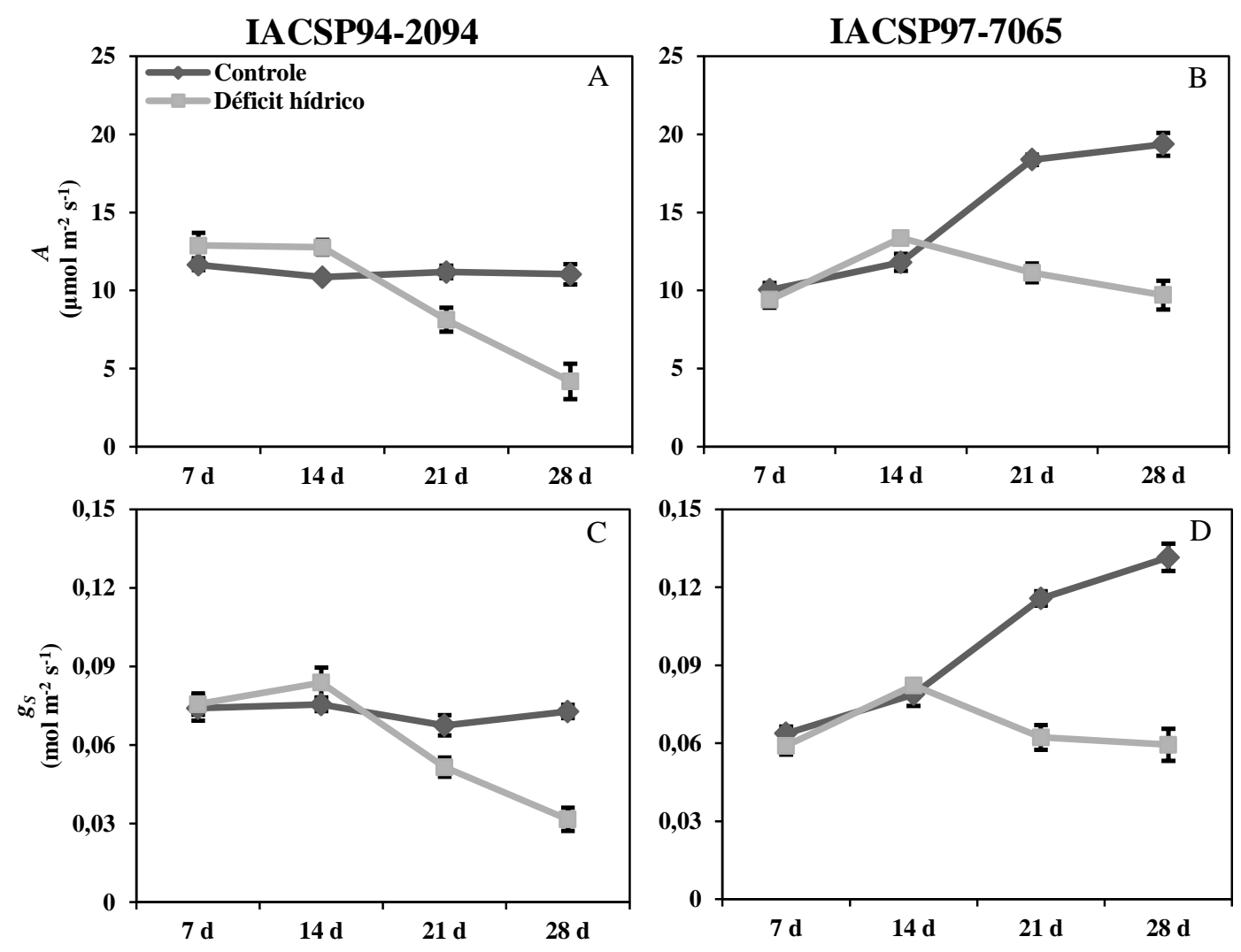

Figura 5 - Assimilação de $\mathrm{CO}_{2}(A)$ e condutância estomática $\left(g_{S}\right)$ nas cultivares 'IACSP94-2094' e 'IACSP97-7065' contrastantes para a resposta à seca ( $1^{\circ}$ experimento). As barras indicam o erro padrão para três repetições biológicas

Portanto, as plantas da cultivar 'IACSP97-7065' sob déficit hídrico não tiveram seus parâmetros de trocas gasosas afetados. Dessa forma, para a confirmação desses resultados e 
investigar as razões para a ausência de imposição de déficit hídrico na cultivar 'IACSP97-7065', o mesmo experimento foi repetido, avaliando outros parâmetros fisiológicos, como potencial hídrico ( $\Psi)$, conteúdo relativo de água (CRA), massa seca (MS), potencial hídrico do solo, assimilação de $\mathrm{CO}_{2}(A)$, condutância estomática $\left(g_{S}\right)$, transpiração (E) e fluorescência da clorofila.

Os experimentos foram realizados em condições climáticas diferentes, pois o primeiro experimento foi conduzido durante a primavera, e o período de máximo déficit hídrico ocorreu 28 dias após a suspensão da irrigação, enquanto que no segundo experimento, realizado durante o inverno, o período de máximo déficit hídrico ocorreu 41 dias após a suspensão da irrigação.

Durante o experimento realizado no inverno, o potencial hídrico da folha foi afetado pela seca em ambas as cultivares. Entretanto, apenas cultivar 'IACSP94-2094' apresentou redução no potencial hídrico da folha aos 7 DAT (Figura 6 A). Contudo, a indisponibilidade de água reduziu o potencial hídrico em ambas as cultivares aos 41 DAT (Figura 6) sendo, entretanto, essa redução mais drástica na cultivar 'IACSP94-2094'.

Da mesma forma, o conteúdo relativo de água (CRA) foi menor nas plantas submetidas ao déficit hídrico durante o período de seca máxima, quando comparadas ao controle em ambas as cultivares estudadas, contudo, a cultivar 'IACSP94-2094' foi mais afetada pela seca (Figura 7). A restrição hídrica também resultou em menor pressão de água no solo ao longo do tratamento, indicada pelos tensiômetros colocados no solo dos vasos contendo as plantas (Figura 8), sendo que a cultivar 'IACSP94-2094' apresentou diminuição da pressão da água no solo antecipadamente em relação a cultivar 'IACSP97-7065'.

A massa seca (MS) relativa às folhas e colmos das duas cultivares de cana-de-açúcar sob condições de seca (41 DAT) foi estimada. Não foi observada diferença significativa para MS entre as plantas controle e sob condições de seca para a 'IACSP94-2094' (Figura 9 A). Similarmente, foi obsevado o mesmo comportamento na 'IACSP97-7065', onde nenhuma diferença entre os tratamentos foi evidente (Figura 9 B). Entretanto, a cultivar 'IACSP94-2094' (tolerante) apresentou o dobro da massa seca observada na 'IACSP97-7065' (sensível) (Figura 9). 

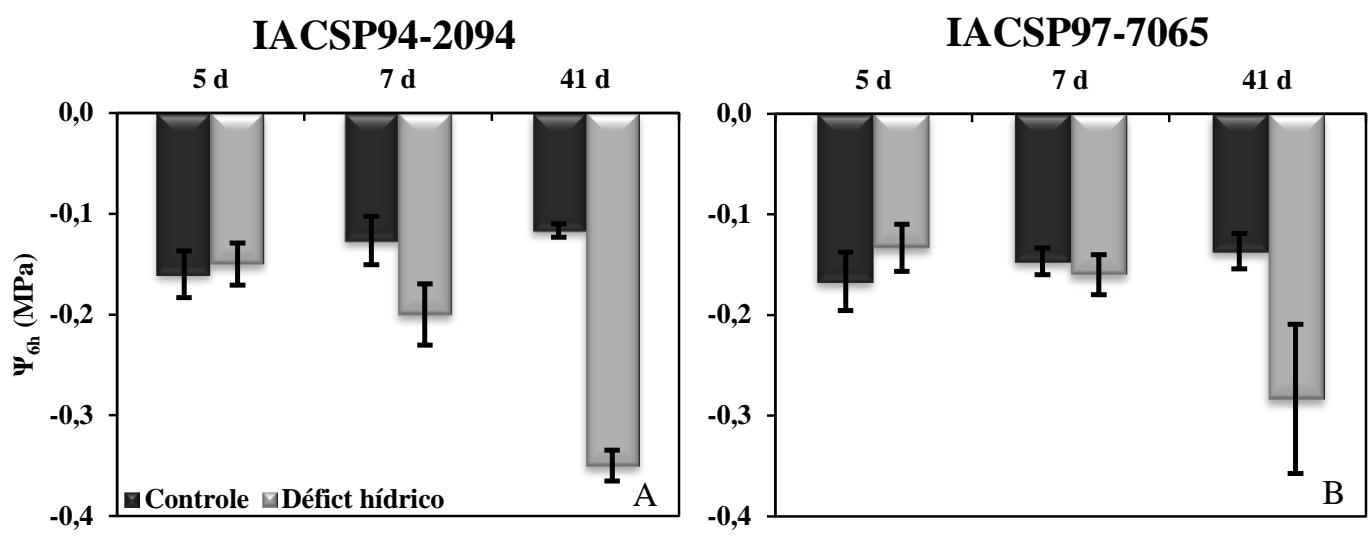

Figura 6 - Pontecial hídrico da folha ( $\Psi$ - MPa) nas cultivares 'IACSP94-2094' e 'IACSP97-7065' sob condições de seca ( $2^{\circ}$ experimento). As barras indicam o erro padrão para três repetições biológicas
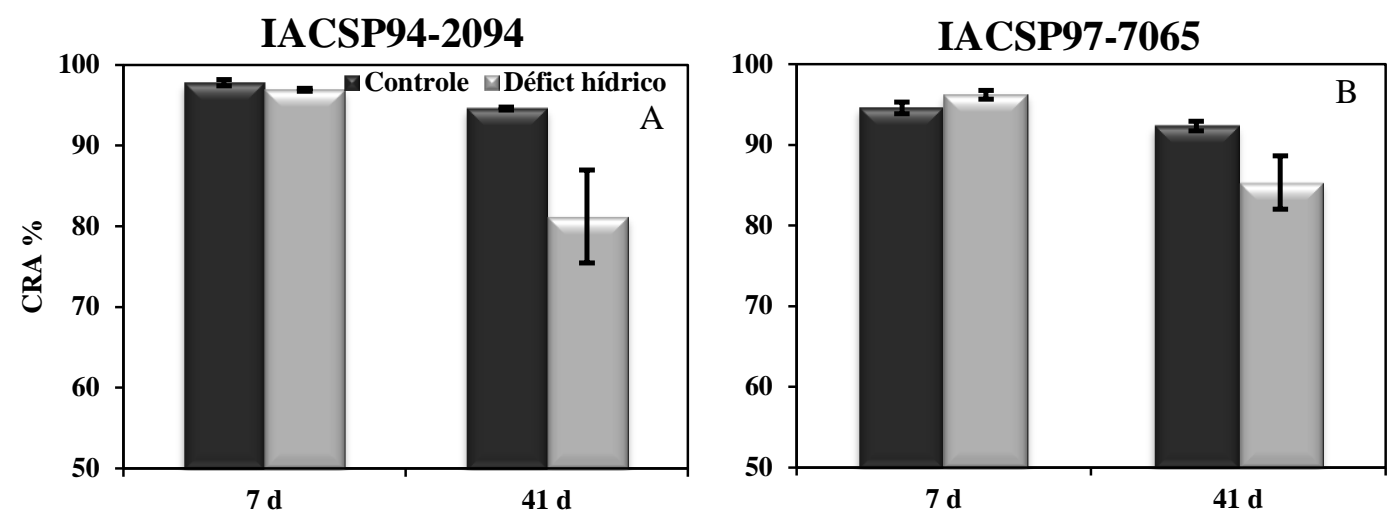

Figura 7 - Conteúdo Relativo de Água (CRA) de folha nas cultivares 'IACSP94-2094' e 'IACSP97-7065' sob condições de seca ( $2^{\circ}$ experimento). As barras indicam o erro padrão para três repetições biológicas

IACSP94-2094

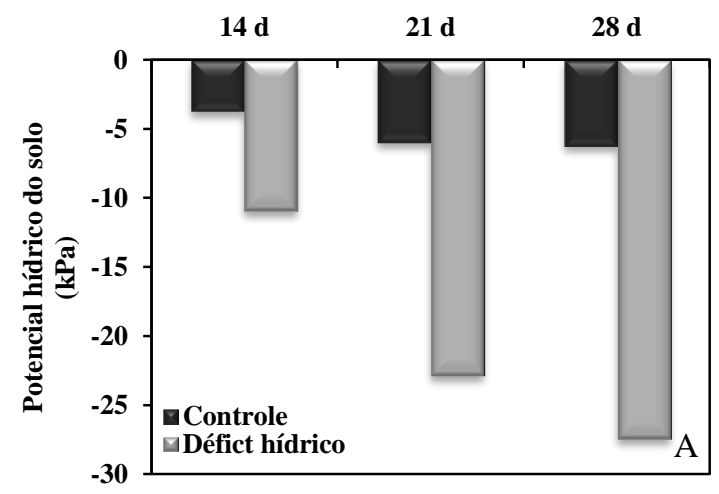

IACSP97-7065

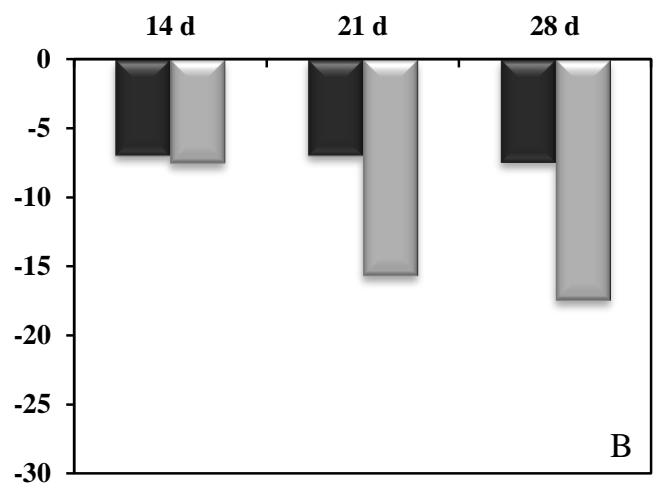

Figura 8 - Pressão de água no solo $(\mathrm{kPa})$, realizado nos períodos de 14, 21 e 28 dias após a suspensão da água, nas cultivares 'IACSP94-2094' e 'IACSP97-7065' contrastantes para a resposta à seca ( $2^{\circ}$ experimento) 

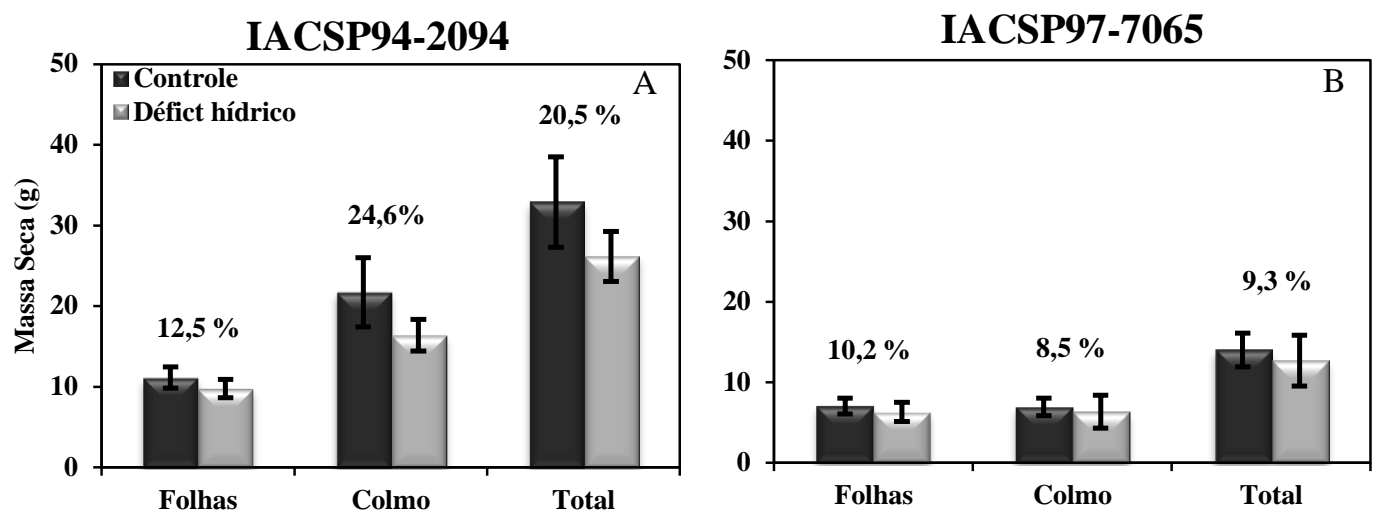

Figura 9 - Massa seca (g) da parte aérea de cana-de-açúcar (folha e colmo) 41 dias após a suspensão da água, nas cultivares 'IACSP94-2094' e 'IACSP97-7065' contrastantes para a resposta à seca ( $2^{\circ}$ experimento). As barras indicam o erro padrão para três repetições biológicas

As plantas do segundo experimento (inverno) foram avaliadas em relação às medidas de trocas gasosas: assimilação de $\mathrm{CO}_{2}(A)$; condutância estomática $\left(g_{S}\right)$ e transpiração $(E)$.

A assimilação de $\mathrm{CO}_{2}$ na cultivar 'IACSP94-2094' sofreu redução a partir de 14 até 41 DAT em relação às plantas controle, sendo muito drástica no último período amostrado (Figura 10 A). Para a cultivar 'IACSP97-7065' foi observado um ligeiro aumento na fotossíntese aos 14 DAT nas plantas submetidas à seca e posterior queda aos 21 até 41 DAT. Porém, a queda foi menos expressiva do que a observada na cultivar 'IACSP94-2094' (Figura $10 \mathrm{~B}$ ).

O fechamento estomático das plantas sob restrição hídrica da cultivar 'IACSP94-2094' iniciou-se aos 14 DAT, perdurando até 41 DAT (Figura $10 \mathrm{C}$ ). A transpiração na cultivar tolerante diminuiu a partir de 21 DAT (Figura 10 E). Similarmente, diante da seca, houve fechamento estomático na cultivar sensível ('IACSP97-7065') a partir de 21 DAT (Figura 10 D), período também relacionado à diminuição na transpiração (Figura $10 \mathrm{~F}$ ).

O déficit hídrico influencia as reações bioquímicas da fotossíntese, e dessa forma as medidas fotoquímicas podem ser um indicativo dos danos causados ao aparato fotossintético. Dessa forma, os parâmetros fotoquímicos avaliados foram: eficiência quântica potencial $\left(F_{v} / F_{m}\right)$ e eficiência quântica efetiva $\left(\Delta F / F_{m}{ }^{\prime}\right)$ do fotosistema II (PSII); transporte aparente de elétrons $(E T R)$ e coeficiente de extinção fotoquímico $(q P)$. 

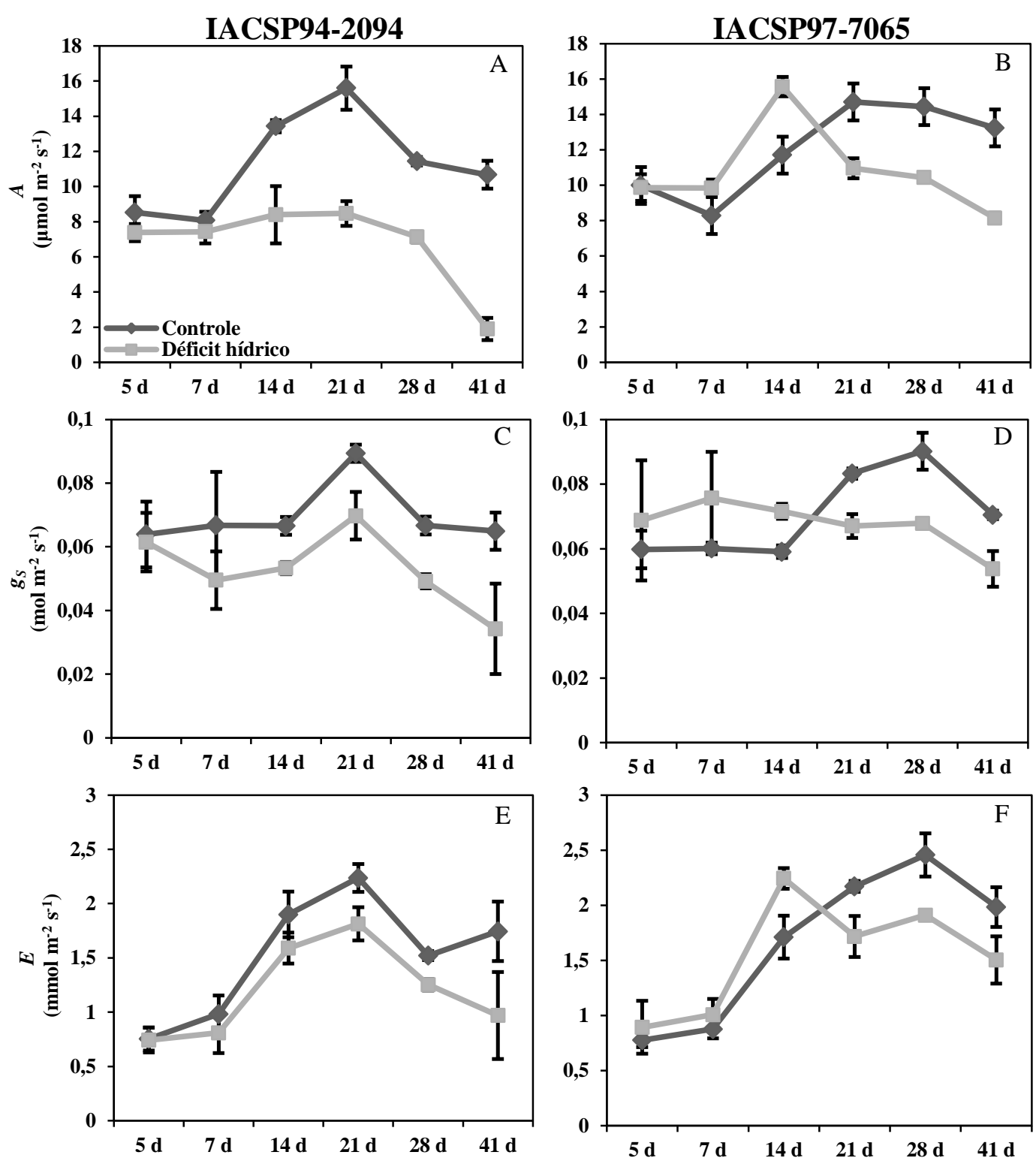

Figura 10 - Assimilação de $\mathrm{CO}_{2}\left(A-\mu \mathrm{mol} \mathrm{m} \mathrm{m}^{-2} \mathrm{~s}^{-1}\right)$, condutância estomática $\left(\mathrm{g}_{S}-\mathrm{mol} \mathrm{m}^{-2} \mathrm{~s}^{-1}\right) \mathrm{e}$ transpiração $\left(E-\mathrm{mmol} \mathrm{m}^{-2} \mathrm{~s}^{-1}\right)$ nas cultivares 'IACSP94-2094' e 'IACSP97-7065' contrastantes para a resposta à seca ( $2^{\circ}$ experimento). As barras indicam o erro padrão para três repetições biológicas 
$F_{v} / F_{m}$ é uma estimativa da eficiência quântica máxima da atividade fotoquímica do PSII, quando todos os centros de reação do PSII estão abertos para receber energia luminosa que chega a planta (BAKER; ROSENQVIST, 2004). Na cultivar tolerante ('IACSP94-2094'), houve redução na $F_{\downarrow} / F_{m}$ somente em condições de estresse máximo (41 DAT) (Figura $11 \mathrm{~A}$ ), e na sensível ('IACSP97-7065') apenas uma pequena redução aos 21 DAT, porém, não foi observada diferença durante o período de estresse máximo (Figura 11 B). Entretanto, a $\Delta F / F_{m}{ }^{\prime}$, que indica a proporção de luz absorvida pela clorofila associada ao PSII utilizada na atividade fotoquímica (BAKER; ROSENQVIST, 2004) e o transporte aparente de elétrons $(E T R)$, medida da atividade fotoquímica, sofreram redução significativa na cultivar tolerante ('IACSP94-2094') a partir de 14 DAT (Figura 11 C, E). Enquanto na cultivar sensível ('IACSP97-7065') a queda no $\Delta F / F_{m}$ ' e ETR foi observada somente a partir de 21 DAT, porém menos expressiva que na cultivar 'IACSP94-2094' (Figura 11 D, F).

O coeficiente de extinção fotoquímico $(q P)$ é uma medida indicativa do número de centro de reações do fotossistema II que estão abertos para receber a energia luminosa que chega na planta (MAXWELL; JOHNSON, 2000). Na 'IACSP94-2094', o $q P$ sofreu redução de 14 até 41 DAT quando comparado com o controle, mas sem diferença significativo aos 41 DAT (Figura 11 G), enquanto que a 'IACSP97-7065', sofreu redução de 21 até 41 DAT, e aos 41 DAT também sem diferença significativa (Figura $11 \mathrm{H}$ ). 

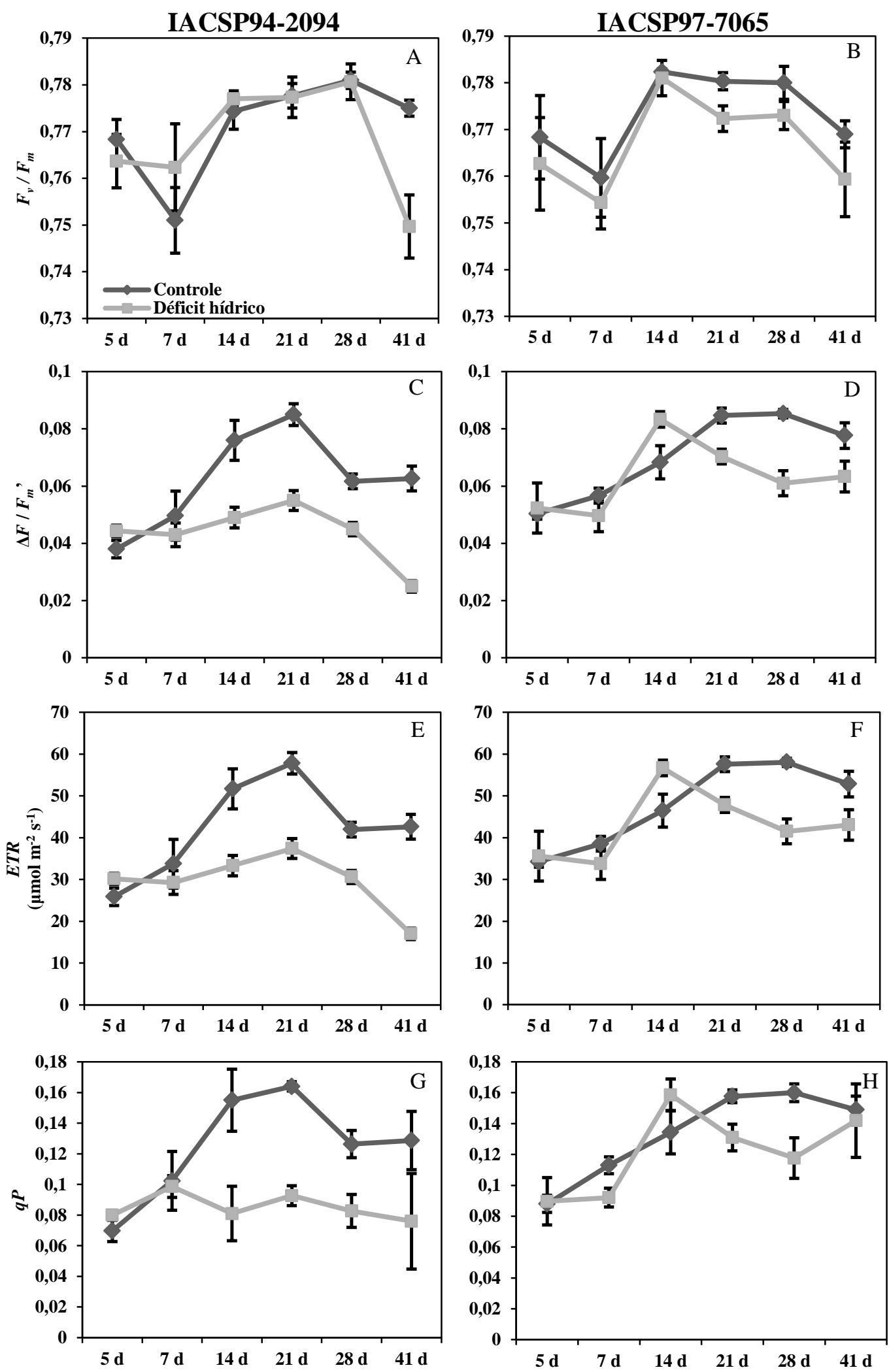

Figura 11 - Eficiência quântica potencial $\left(F_{\downarrow} / F_{m}\right)$ e eficiência quântica efetiva $\left(\Delta F / F_{m}{ }^{\prime}\right)$ do fotosistema II (PSII), taxa de transporte aparente de elétrons $(E T R)$ e coeficiente de extinção fotoquímico $(q P)$ nas cultivares 'IACSP94-2094' e 'IACSP97-7065' contrastantes para a resposta à seca ( $2^{\circ}$ experimento). As barras indicam o erro padrão para três repetições biológicas 


\subsection{Peroxidação lipídica}

No segundo experimento foi avaliado o nível de peroxidação lipídica como parâmetro para indicativo da ocorrência de estresse oxidativo nas plantas. A peroxidação lipídica foi determinada pela estimativa do conteúdo de substâncias reativas ao ácido tiobarbitúrico (TBARS). Incremento no conteúdo de MDA foi encontrado para ambas as cultivares. Entretanto, para a cultivar tolerante ('IACSP94-2094'), ocorreu aumento do conteúdo de MDA em todos os períodos amostrados, com a exceção de 14 DAT de suspensão da água, enquanto que para a cultivar sensível ('IACSP97-7065') o aumentou da concentração de MDA foi apenas aos 41 DAT de déficit hídrico (Figura 12).
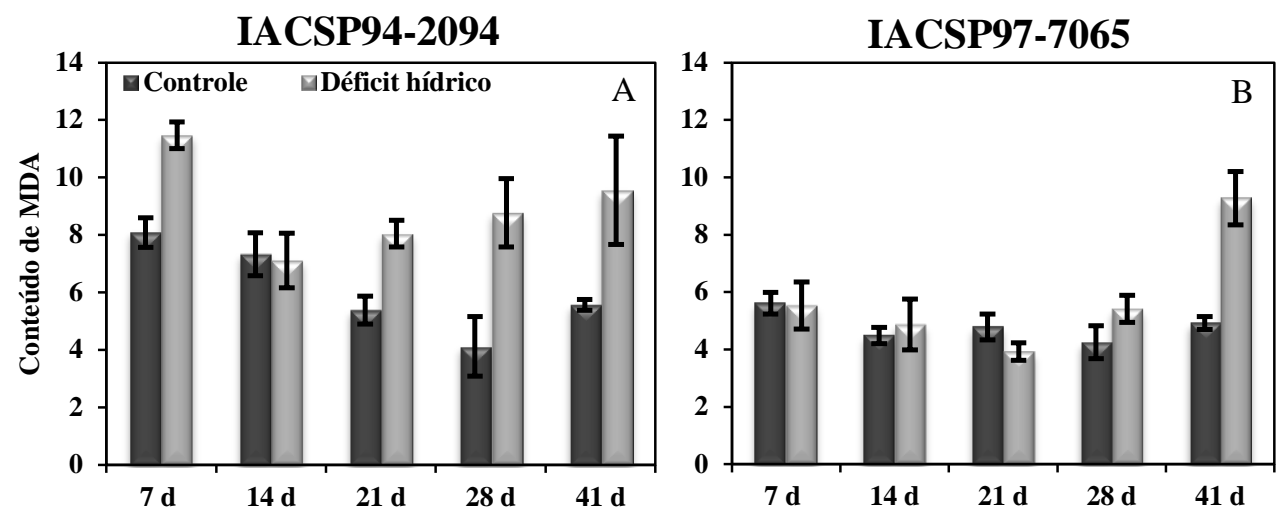

Figura 12 - Peroxidação lipídica, expressa através do conteúdo de MDA (nmol/g MF) em folha de cana-de-açúcar das cultivares 'IACSP94-2094' e 'IACSP97-7065', 7, 14, 21, 28 e 41 dias após a suspensão da água ( $2^{\circ}$ experimento). As barras indicam o erro padrão para três repetições biológicas

\subsection{Atividade específica e expressão gênica das enzimas do sistema antioxidante}

As análises de atividade específica e expressão gênica das enzimas do sistema antioxidante se referem ao primeiro experimento, conduzido durante a primavera.

\subsubsection{Superóxido dismutase (SOD)}

A SOD primeira enzima do ciclo ascorbato-glutationa a atuar no controle de ROS, teve sua atividade determinada por espectrofotometria. Aos 7 DAT sob condições de seca foi possível observar um aumento na atividade da SOD em ambas cultivares quando comparadas com as plantas controle (Figura 13), sendo que a 'IACSP97-7065', apresentou atividade enzimática mais expressiva do que a 'IACSP94-2094' (Figura 13 B). De 14 até 21 DAT não 
houve diferenças significativas entre os tratamentos para ambas as cultivares (Figura 13), não sendo observada nenhuma alteração fenotípica induzida pela seca. Porém, aos 28 DAT sob condições de seca, período em que se iniciaram os sintomas visuais de déficit hídrico nas plantas (Figuras 3 e 4), foi observada atividade significativa de SOD na 'IACSP94-2094' em relação às plantas controle (Figura 13 A), diferentemente da 'IACSP97-7065' que não exibiu atividade diferenciada da SOD em relação às plantas controle neste tempo amostral (Figura 13 B).
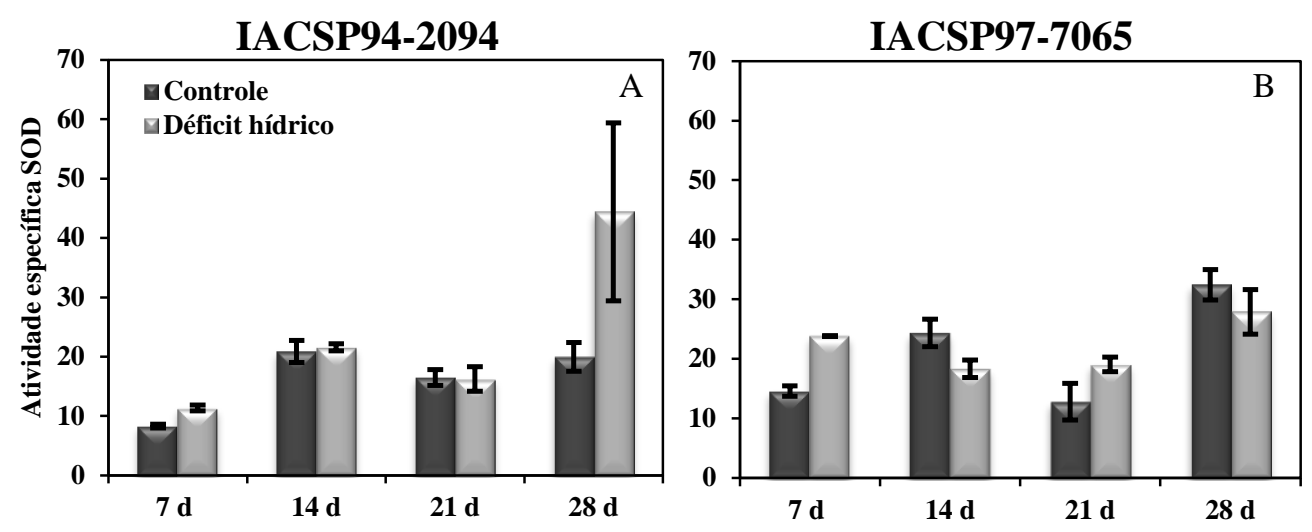

Figura 13 - Atividade específica da superóxido dismutase (SOD) (U SOD mg ${ }^{-1}$ proteína) em folha de cana-de-açúcar das cultivares 'IACSP94-2094' e 'IACSP97-7065', 7, 14, 21 e 28 dias após a suspensão da água ( $1^{\circ}$ experimento). As barras indicam o erro padrão para três repetições biológicas

As atividades das enzimas SOD foliares de cana-de-açúcar também foram avaliadas qualitativamente por PAGE nativo. A atividade da SOD em PAGE revelou a presença de cinco isoformas para a cultivar tolerante ('IACSP94-2094') e quatro isoformas para a cultivar sensível ('IACSP97-7065') (Figura 14). Aos 7 DAT não foi perceptível nenhum aumento da intensidade das bandas quando comparada com o controle para ambas as cultivares (Figura 14 A, C). Entretanto, aos 28 DAT, a cultivar tolerante apresentou um ligeiro aumento na atividade da SOD, sendo verificada uma intensidade maior das bandas I e V (Figura 14 B). Além disso, a 'IACSP94-2094' apresentou duas isoformas (bandas IV e VI) exclusivas, quando comparada com a 'IACSP97-7065' (Figura 14 B, D). Na cultivar 'IACSP97-7065', aos 28 DAT foi perceptível um aumento da atividade da SOD (banda V), e também a exclusividade da banda II. Entretanto, não foi visualizada nenhuma banda diferente entre os períodos de seca inicial e seca máxima para ambas as cultivares (Figura 14). 


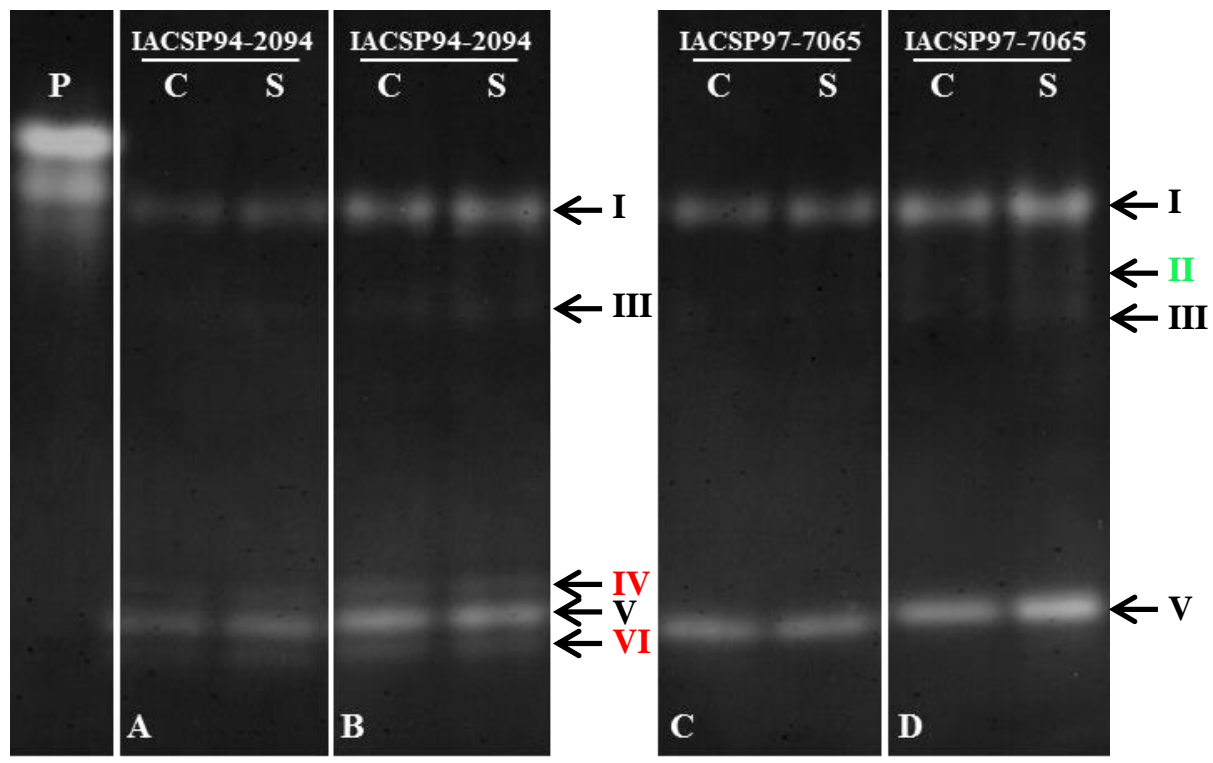

Figura 14 - Análise da atividade da SOD em PAGE nativo para cultivares de cana-de-açúcar. 'IACSP94-2094' (A) 7 dias e (B) 28 dias de suspensão da água; 'IACSP97-7065' (C) 7 dias e (D) 28 dias após suspensão da água. As setas indicam as diferentes isoformas encontradas no controle (C), aos 7 e 28 dias após suspensão da água (S). Padrão (P) SOD bovino. Em vermelho, isoforma exclusiva da cultivar 'IACSP94-2094' e em verde isoforma exclusiva da cultivar 'IACSP97-7065' ( $1^{\circ}$ experimento)

As isoformas da SOD também foram caracterizadas por PAGE nativo, sendo detectada a existência de diferentes isoformas em folha de cana-de-açúcar em ambas as cultivares (Figura 15). Nas amostras de 'IACSP94-2094' (tolerante) foi posssível observar duas isoformas (bandas II e IV) que não estão presentes no gel de atividade da SOD (Figura 14), isso pode ser resultado da concentração total de proteína aplicada no poço, pois para a caracterização utiliza-se uma quantidade bem maior de extrato protéico. Com isso, para esta cultivar foi encontrado ao todo uma isoforma Mn-SOD; quatro isoformas Fe-SOD e duas isoformas Cu/Zn-SOD. As bandas IV, V e VII são exclusivas da cultivar 'IACSP94-2094' (Figura 15), sendo que, a banda IV corresponde a Cu/Zn-SOD, e as bandas V e VII foram caracterizadas como Fe-SOD.

No gel de caracterização de isoformas para a cultivar sensível ('IACSP97-7065') foi encontrado uma isoforma Mn-SOD; duas isoformas Fe-SOD e uma isoforma Cu/Zn-SOD (Figura 16). Para esta cultivar o número total de isoformas encontradas foram quatro, enquanto que na tolerante ('IACSP94-2094') foram sete isoformas. Isso demonstra que as cultivares possuem um perfil diferenciado quanto às isoformas de SOD que estão ativas. 


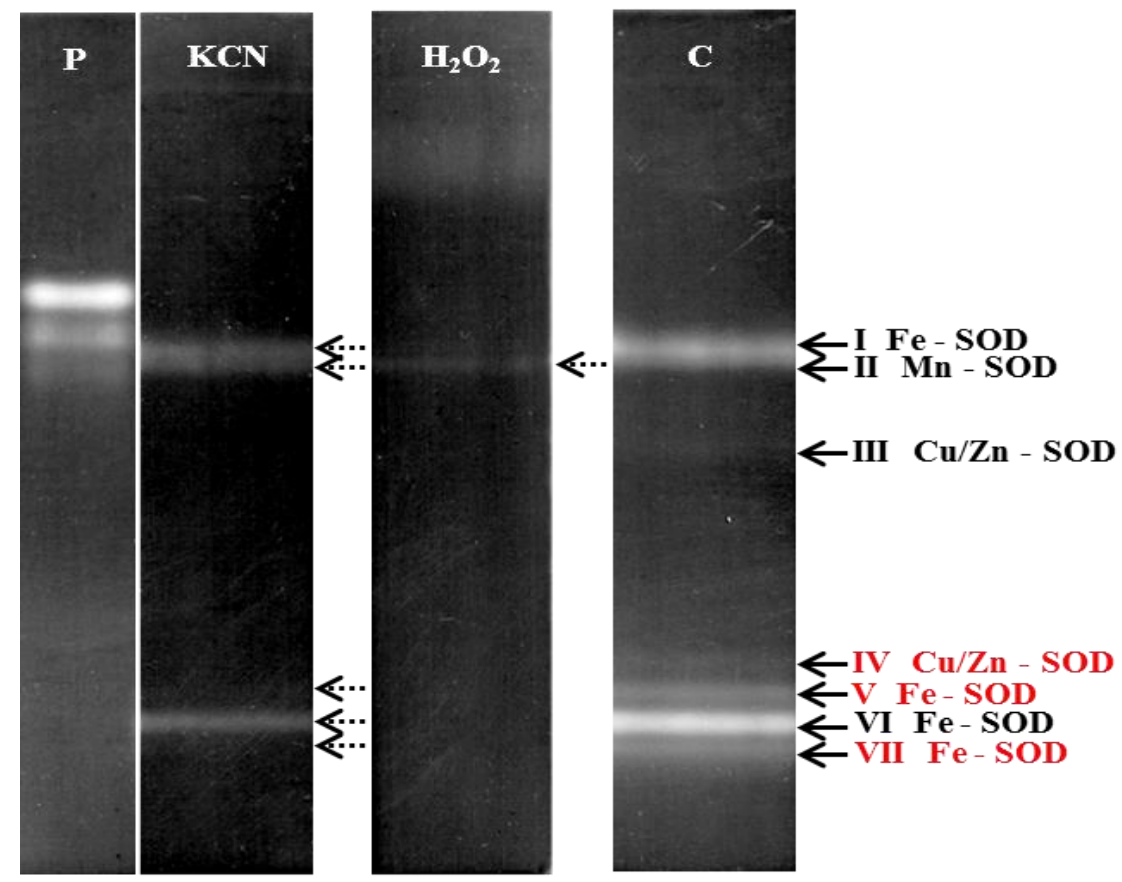

Figura 15 - Caracterização das isoformas da SOD para a cultivar 'IACSP94-2094'. Padrão (P) SOD bovino, controle (C), $\mathrm{KCN} 2 \mathrm{mM}$ e $\mathrm{H}_{2} \mathrm{O}_{2} 5 \mathrm{mM}$. Em vermelho, isoforma exclusiva desta cultivar ( $1^{\circ}$ experimento)

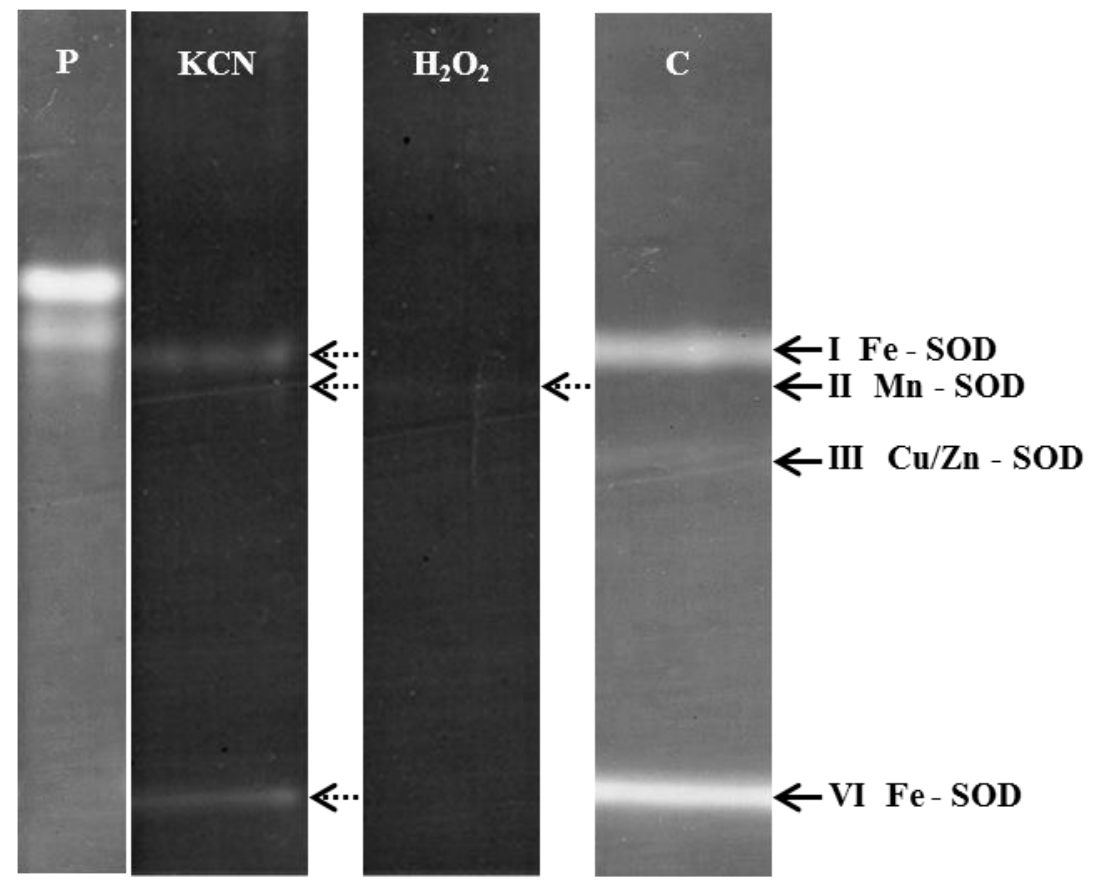

Figura 16 - Caracterização das isoformas da SOD para a cultivar 'IACSP97-7065'. Padrão (P) SOD bovino, controle (C), $\mathrm{KCN} 2 \mathrm{mM} \mathrm{e} \mathrm{H}_{2} \mathrm{O}_{2} 5 \mathrm{mM}$ ( $1^{\circ}$ experimento) 
Com o objetivo de caracterizar os genes diferencialmente expressos durante o estresse hídrico, estudos de análise quantitativa de transcritos foram realizados para a SOD, sendo avaliada a SOD1.1, que se refere a isoforma Mn-SOD, e a SOD 1.2, SOD 2.1.1 e SOD 3 que se referem a isoforma $\mathrm{Cu} / \mathrm{Zn}$-SOD. A classificação das isoformas de SOD foi realizada de acordo com o banco de dados Computational Biology and Functional Genomics Laboratory Saccharum Gene Index.

A expressão do gene referente a SOD 1.1 e SOD 2.1.1 apresentaram aumento no nível de transcritos aos 21 DAT para a cultivar tolerante ('IACSP94-2094') (Figura 17 A, E). Enquanto que para a 'IACSP97-7065', o aumento no nível de transcritos ocorreu a partir de 21 até 28 DAT para a SOD 1.1 (Figura $17 \mathrm{~B}$ ), e aos 21 DAT para a isoforma SOD 1.2 (Figura 17 D). 

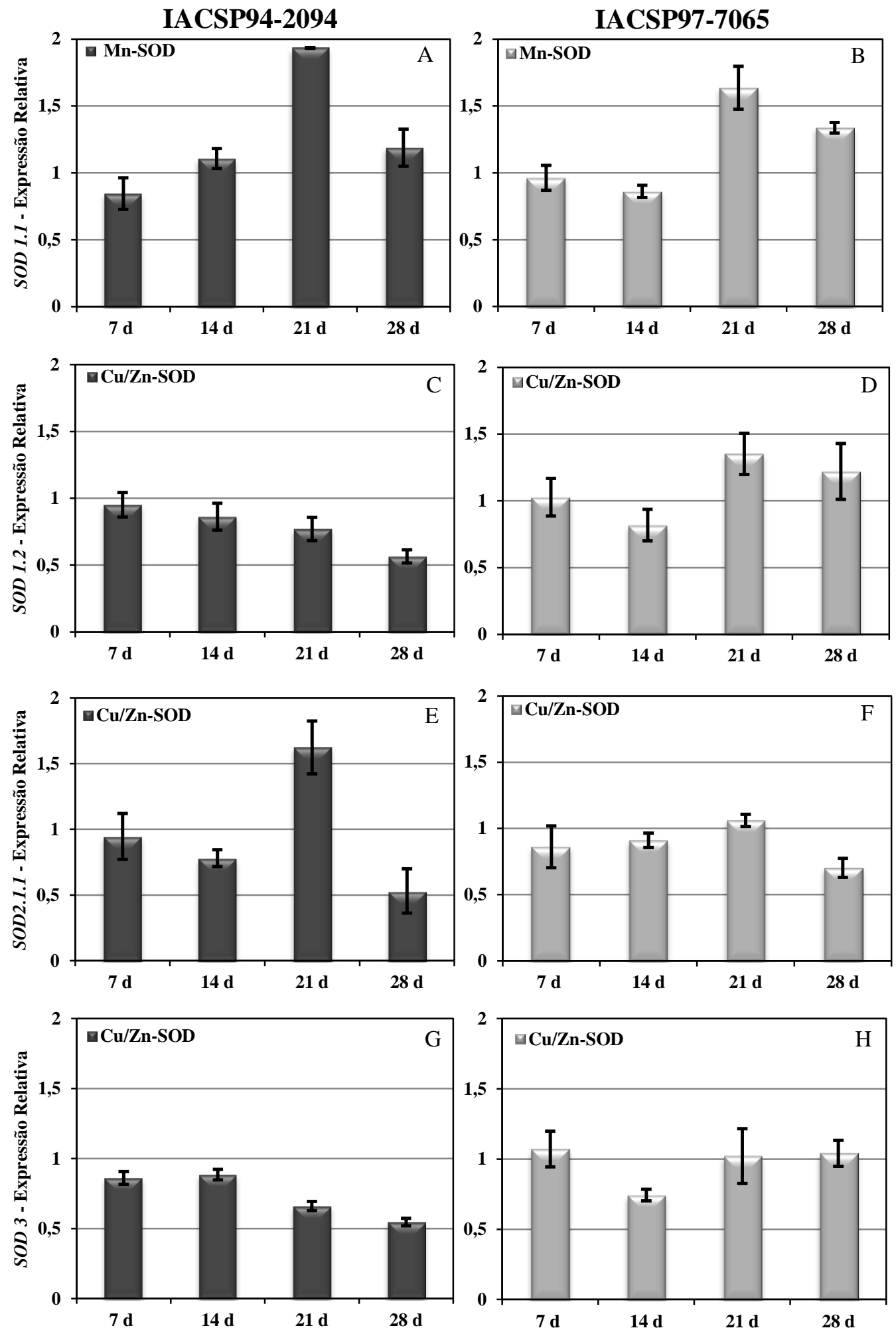

Figura 17 - Perfil de expressão relativa dos genes SOD 1.1, SOD 1.2, SOD 2.1.1 e SOD 3 no tratamento de seca em relação ao controle irrigado para as cultivares 'IACSP94-2094' e 'IACSP97-7065' ( $1^{\circ}$ experimento). As barras indicam o erro padrão para três repetições biológicas 


\subsubsection{Ascorbato peroxidase (APX)}

Por meio de espectrofotometria foi analisada a atividade específica da enzima APX, a qual possui maior afinidade pelo substrato $\mathrm{H}_{2} \mathrm{O}_{2}$. Os ensaios de atividade enzimática conduzidos para a enzima APX detectaram comportamento similar ao observado na enzima SOD. Dessa forma, a atividade da APX com 7 DAT, foi maior em ambas as cultivares nas plantas sob seca em relação as plantas controle, não havendo porém, diferenças significativas entre os tratamentos em ambas as cultivares aos 14 DAT de seca (Figura 18). Aos 21 DAT de seca, notou-se em ambas cultivares uma atividade significativamente maior em relação ao controle, sendo que a mais expressiva foi observada na cultivar 'IACSP97-7065' (Figura 18 B). Aos 28 DAT de seca foi notada uma alta atividade de APX na 'IACSP94-2094' (tolerante) quando comparada com as plantas controle (Figura 18 A), similar àquela encontrada na 'IACSP97-7065' (sensível), porém sem diferenças significativas em relação ao controle (Figura18 B).
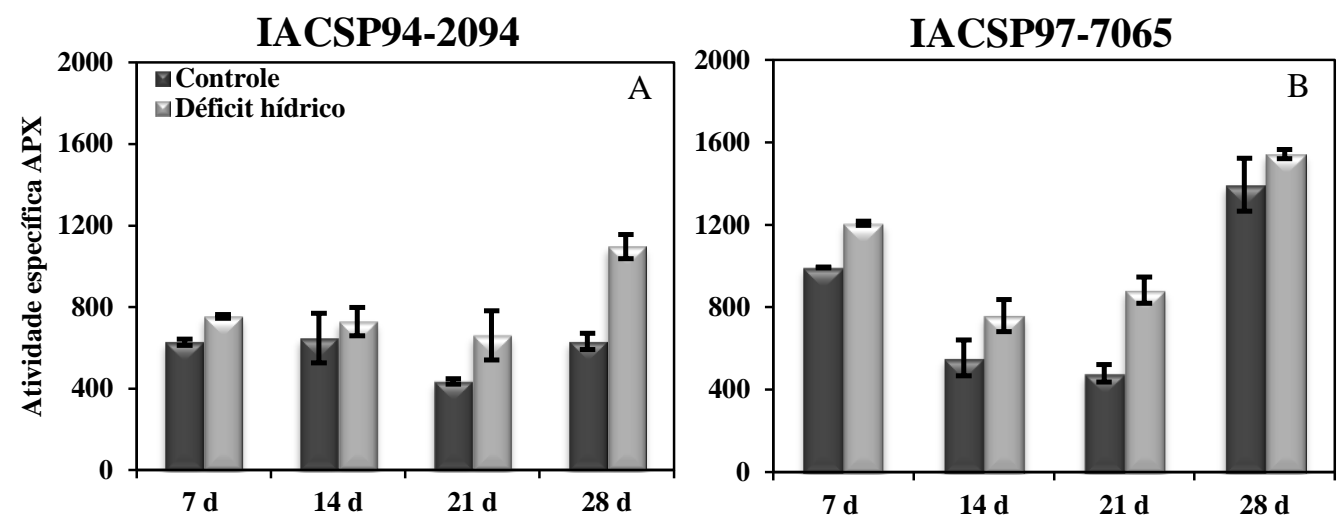

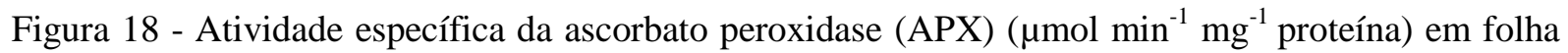
de cana-de-açúca das cultivares 'IACSP94-2094' e 'IACSP97-7065', 7, 14, 21 e 28 dias após a suspensão da água ( $1^{\circ}$ experimento). As barras indicam o erro padrão para três repetições biológicas

A expressão relativa dos genes referentes a quatro isoformas de APX em cana-de-açúcar ( $A P X$ 1, $A P X$ 2.1, $A P X 3$ e $A P X 4)$ foi avaliada neste trabalho em resposta ao estresse por seca.

A expressão quantitativa da $A P X 1$ apresentou uma indução da expressão aos 21 DAT de seca somente para a cultivar sensível ('IACSP97-7065') (Figura 19 B). Com relação à APX 2.1, houve aumento no nível de expressão aos 21 DAT permanecendo até 28 DAT na 'IACSP97-7065' (Figura 19 D). A APX 3 não mostrou indução para nenhuma cultivar em todos os períodos amostrados (Figura 19 E, F). Já a $A P X 4$ foi a única que teve aumento nos níveis de transcritos para a cultivar tolerante ('IACPS94-2094'), apenas no período de 7 DAT 
de imposição do déficit hídrico, enquanto que nos outros períodos analisados este gene foi regulado negativamente (Figura 19 G), e para a cultivar sensível ('IACSP97-7065') o gene da APX 4 foi regulado negativamente em todos os períodos amostrados (Figura $19 \mathrm{H}$ ).
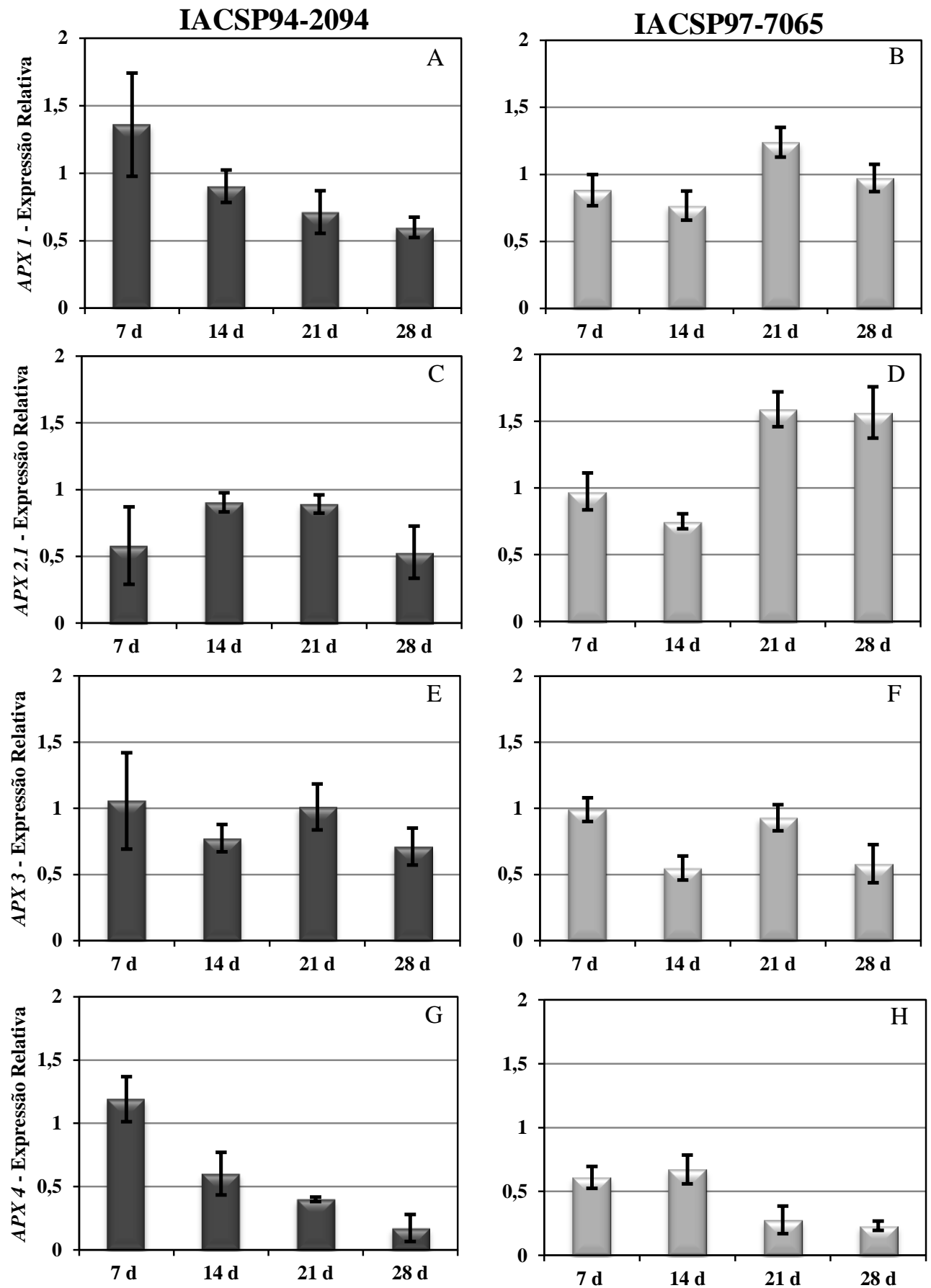

Figura 19 - Perfil de expressão relativa dos genes APX 1, APX 2.1, APX 3 e APX 4 no tratamento de seca em relação ao controle irrigado para as cultivares 'IACSP94-2094' e 'IACSP97-7065' ( $1^{\circ}$ experimento). As barras indicam o erro padrão para três repetições biológicas 


\subsubsection{Catalase (CAT)}

A catalase, enzima que auxilia o ciclo ascorbato-glutationa no controle de $\mathrm{H}_{2} \mathrm{O}_{2}$, teve sua atividade específica analisada por espectrofotometria. De forma geral, houve baixa atividade de CAT em ambas cultivares na maioria dos períodos de seca amostrados (Figura 20), destacando-se um aumento na atividade da enzima nas plantas sob estresse comparada as plantas controle em ambas as cultivares no período de 7 DAT (Figura 20). Aos 21 DAT de seca, houve um ligeiro aumento de atividade da CAT na 'IACSP97-7065' (Figura 20 B).
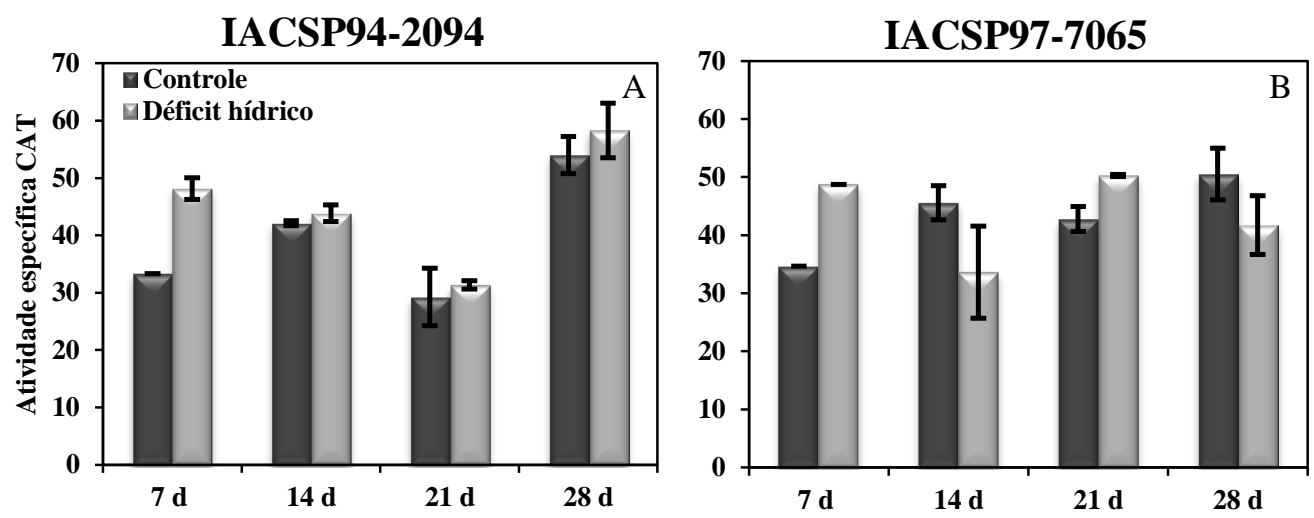

Figura 20 - Atividade específica da catalase (CAT) ( $\mu$ mol $\mathrm{min}^{-1} \mathrm{mg}^{-1}$ proteína) em folha de cana-de-açúcar das cultivares 'IACSP94-2094' e 'IACSP97-7065', 7, 14, 21 e 28 dias após a suspensão da água ( $1^{\circ}$ experimento). As barras indicam o erro padrão para três repetições biológicas.

A análise da atividade da CAT em PAGE nativo revelou a presença de somente uma isoforma da CAT em folhas da 'IACSP94-2094' (tolerante) aos 7 e 28 DAT (Figura 21 A). Entretanto, para a 'IACSP97-7065' (sensível), foram observadas duas isoformas distintas, dependentes do período de seca amostrado: a isoforma I ativa no período de estresse inicial (7 DAT) e a isoforma II ativa no período de estresse máximo (28 DAT) (Figura 21 B). 


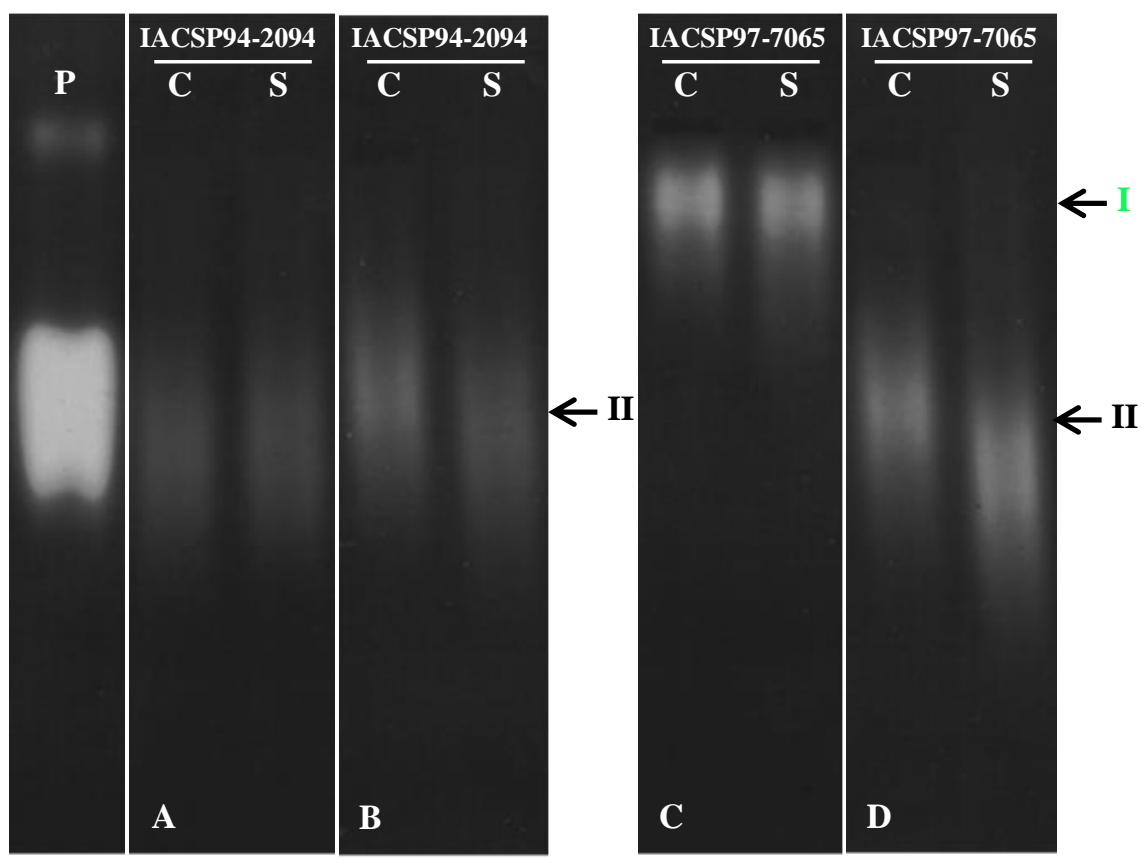

Figura 21 - Análise da atividade da CAT em PAGE nativo para as cultivares de cana-de-açúcar. 'IACSP94-2094' (A) 7 dias e (B) 28 dias após a suspensão da água; 'IACSP97-7065' (C) 7 dias e (D) 28 dias após a suspensão da água. As setas indicam as diferentes isoformas encontradas no controle (C), aos 7 e 28 dias após a suspensão da água (S). Padrão (P). Em verde, isoforma exclusiva da cultivar 'IACSP97-7065' ( $1^{\circ}$ experimento)

Também foram avaliadas a expressão relativa dos genes codificadores referentes às isoformas CAT 1.1, CAT 2.1 e CAT 3.1. A CAT 1.1 apresentou um acúmulo de transcritos aos 14 DAT e 28 DAT para 'IACSP94-2094' (Figura 22 A). Apesar de não ter sido notado aumento na atividade específica por espectrofotometria e PAGE nativo aos 28 DAT na cultivar tolerante, o aumento no nível de transcritos do gene CAT 1.1 pode não ter uma relação temporal com a atividade da enzima. Com relação à isoforma $C A T$ 2.1, não houve aumento de expressão deste gene para nenhuma cultivar nos períodos amostrados (Figura 22 C, D). A expressão quantitativa de transcritos de CAT 3.1 demonstrou aumento da expressão aos 21 e 28 DAT para a cultivar tolerante ('IACSP94-2094') (Figura 22 E), enquanto que para a cultivar sensível ('IACSP97-7065') este gene não foi induzido (Figura $22 \mathrm{~F}$ ). 

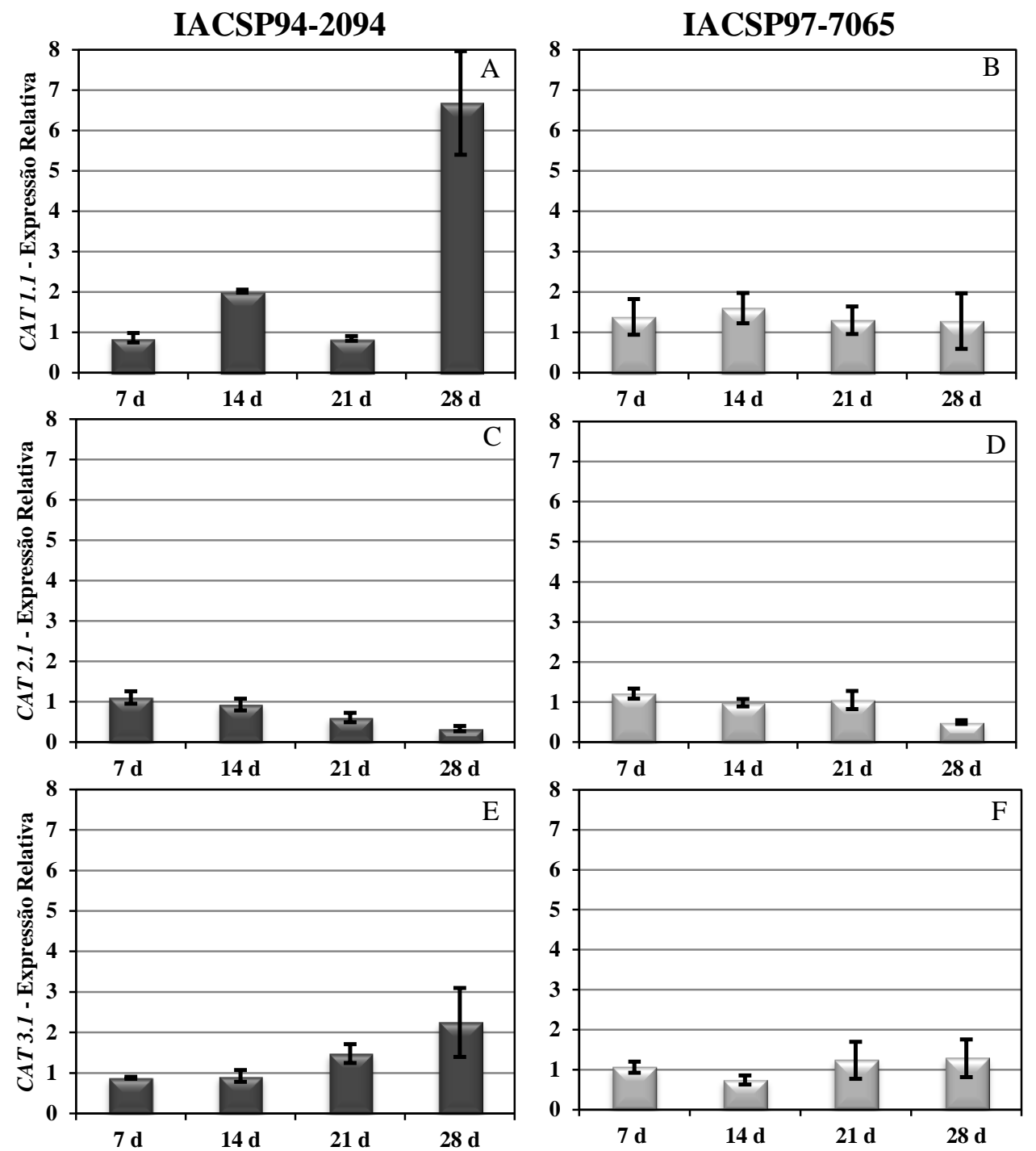

Figura 22 - Perfil de expressão relativa dos genes CAT1.1, CAT 2.1 e CAT 3.1 no tratamento de seca em relação ao controle irrigado para as cultivares 'IACSP94-2094' e 'IACSP97-7065' ( $1^{\circ}$ experimento). As barras indicam o erro padrão para três repetições biológicas

\subsubsection{Glutationa peroxidase (GPX)}

Além das peroxidases APX e CAT estudadas, também foi realizada a avaliação da expressão relativa de outra peroxidase, a glutationa peroxidase (GPX). Para esta peroxidase, foi investigado o perfil de expressão de genes que codificam para três isoformas, GPX 1 , $G P X 2$ e GPX 4.1. De forma geral, as três isoformas não apresentaram acúmulo significativo de transcritos em ambas cultivares para todos os períodos amostrados (Figura 23). 

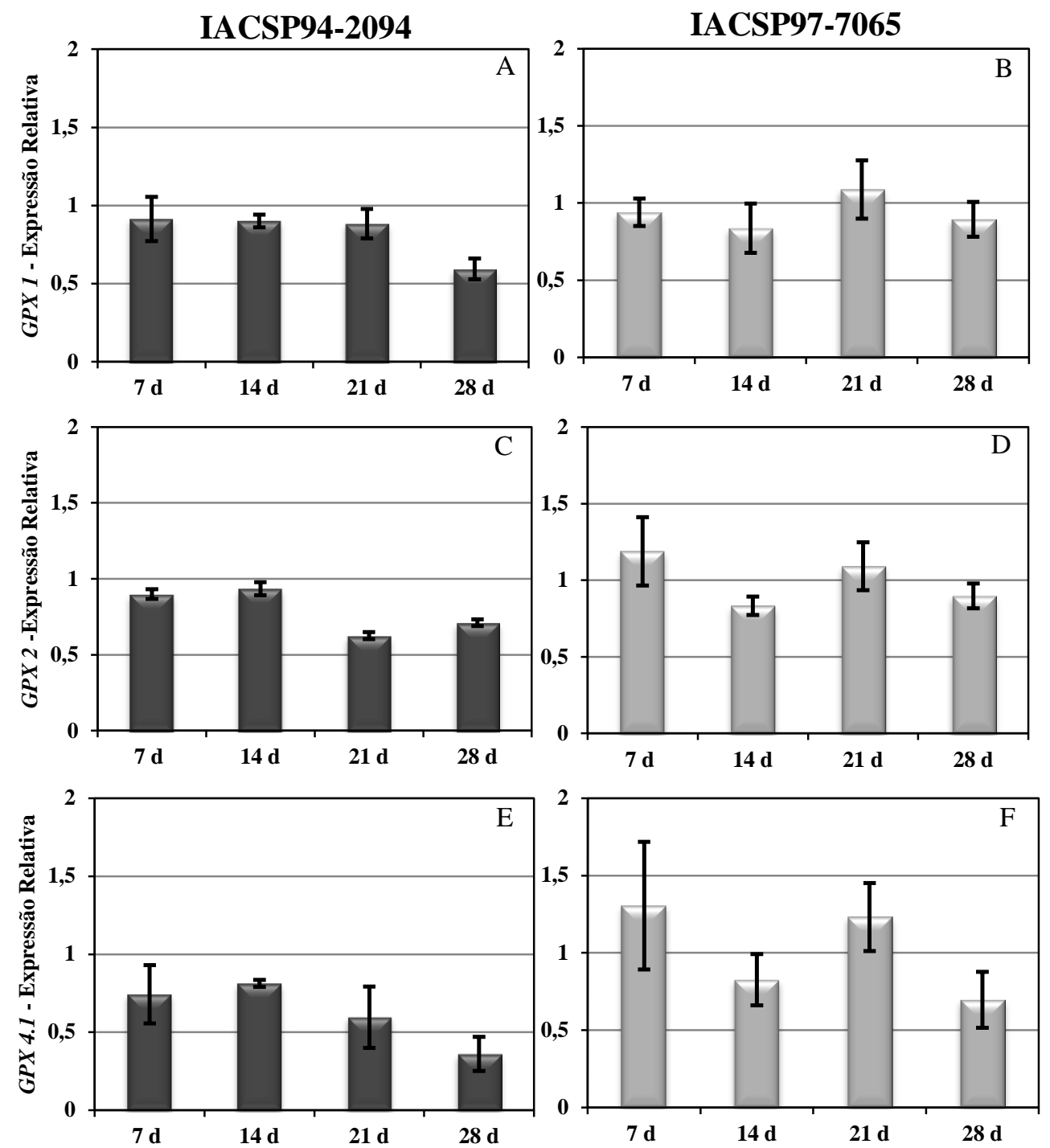

Figura 23 - Perfil de expressão relativa dos genes GPX 1, GPX 2 e GPX 4.1 no tratamento de seca em relação ao controle irrigado para as cultivares 'IACSP94-2094' e 'IACSP97-7065' (1 ${ }^{\circ}$ experimento). As barras indicam o erro padrão para três repetições biológicas

\subsubsection{Glutationa redutase (GR)}

A GR é uma enzima importante no ciclo ascorbato-glutationa, pois mantém os níveis de glutationa reduzida (GSH) que participa do ciclo e atua como antioxidante não enzimático. Foi possível observar atividade da GR em ambas cultivares (Figura 24), sendo na cultivar 'IACSP97-7065' (sensível) aos 14, 21 e 28 DAT (Figura 24 B) e na cultivar 'IACSP94-2094' (tolerante) somente no período de 28 DAT (Figura 24 A). Entretanto, neste período de 
máximo déficit hídrico (28 DAT) para a cultivar tolerante, a atividade da GR foi muito expressiva quando comparada com o controle.

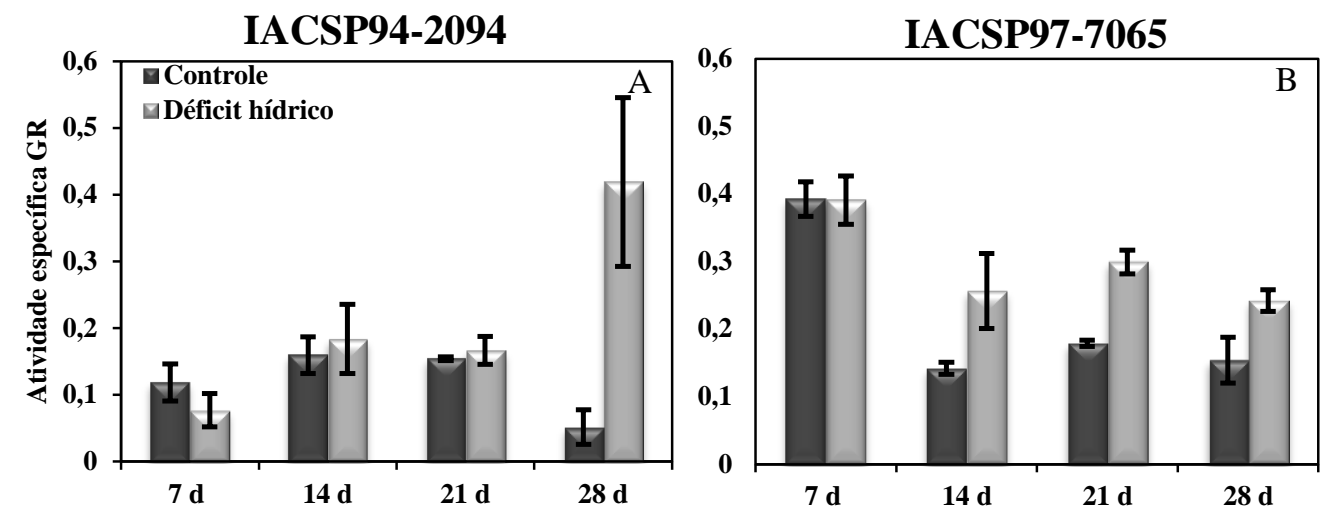

Figura 24 - Atividade específica da glutationa redutase (GR) ( $\mu \mathrm{mol} \mathrm{min}{ }^{-1} \mathrm{mg}^{-1}$ proteína) em folha de cana-de-açúcar das cultivares 'IACSP94-2094' e 'IACSP97-7065', 7, 14, 21 e 28 dias após a suspensão da água ( $1^{\circ}$ experimento). As barras indicam o erro padrão para três repetições biológicas

As atividades das glutationas redutases foliares também foram avaliadas qualitativamente por PAGE nativo. Nas duas cultivares foram encontradas onze isoformas de GR, sendo a banda XII (vermelho) exclusiva da 'IACSP94-2094' e a banda VI (verde) exclusiva da 'IACSP97-7065' (Figura 25). Aos 7 DAT de déficit hídrico período de estresse inicial, no geral foi possível notar um leve aumento da intensidade para todas as bandas quando comparadas com o tratamento controle para a 'IACSP94-2094', indicando maior atividade enzimática (Figura 25 A). Aos 28 DAT, as bandas II, III e IV tiveram um aumento da intensidade quando comparadas ao controle para a cultivar tolerante ('IACSP94-2094'), e com exceção das bandas I, II, III e IV foi possível notar no restante das bandas uma pequena redução na intensidade (Figura 25 B). Na cultivar sensível, aos 7 DAT houve um leve aumento da intensidade na banda VIII (Figura $25 \mathrm{C}$ ), e aos 28 DAT período de estresse máximo, no geral todas as outras bandas tiveram uma redução na intensidade (Figura 25 D). 


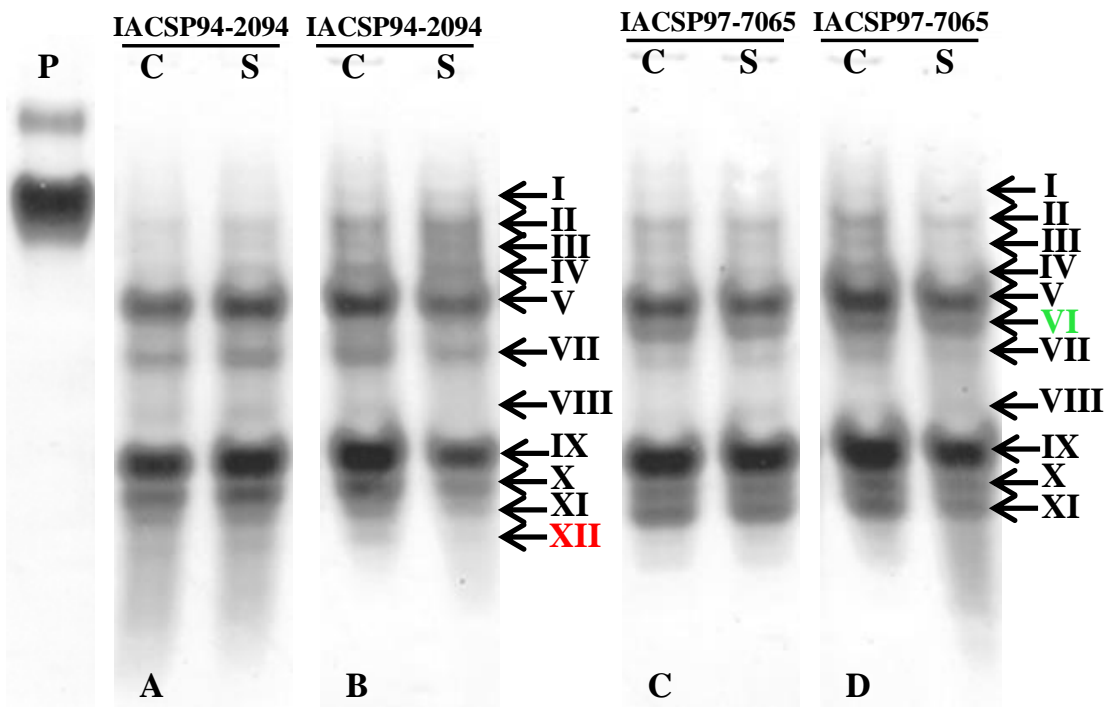

Figura 25 - Análise da atividade da GR em PAGE nativo para cultivares de cana-de-açúcar. 'IACSP94-2094' (A) 7 dias e (B) 28 dias de suspensão da água; 'IACSP97-7065' (C) 7 dias e (D) 28 dias após a suspensão da rega. As setas indicam as diferentes isoformas encontradas no controle (C), aos 7 e 28 dias de suspensão da rega (S). Padrão (P). Em vermelho, isoforma exclusiva da cultivar 'IACSP94-2094' e em verde isoforma exclusiva da cultivar 'IACSP97-7065' ( $1^{\circ}$ experimento)

Além da atividade enzimática, foi investigada também, a expressão gênica de três isoformas de GR, classificadas como GR 1, GR 2 e $G R$ 3. A GR 2 foi a única isoforma que apresentou acúmulo de transcritos para a cultivar tolerante ('IACSP94-2094'); este aumento ocorreu aos 21 e 28 DAT (Figura $26 \mathrm{C}$ ). O acúmulo de transcritos da GR2 pode estar associado com os dados de atividade enzimática obtido por espectrofotometria. Na cultivar sensível ('IACSP97-7065'), as três isoformas da GR não apresentaram aumento significativo do nível de transcritos (Figura 26 B, D, F). 

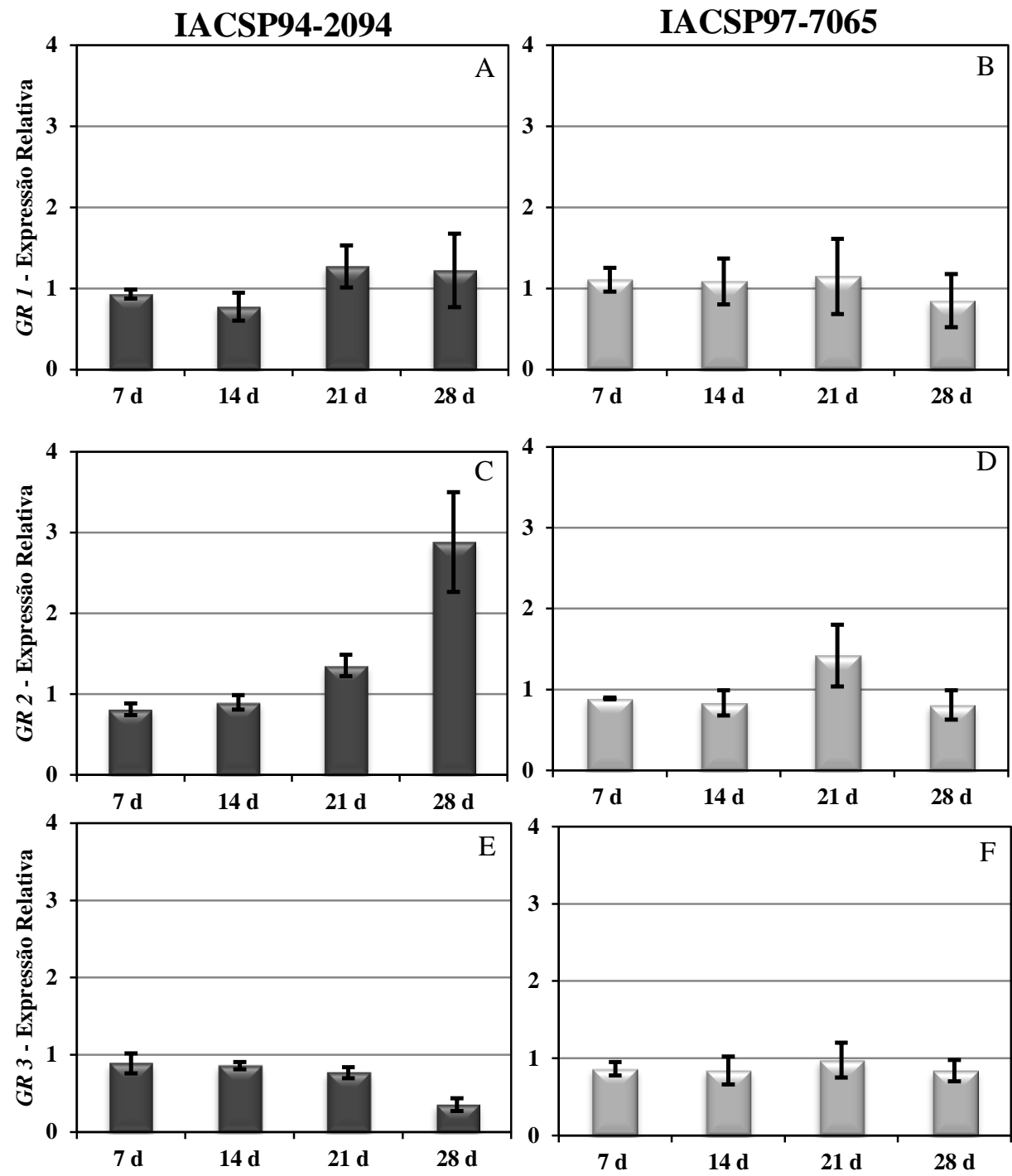

Figura 26 - Perfil de expressão relativa dos genes $G R$ 1, GR 2 e $G R 3$ no tratamento de seca em relação ao controle irrigado para as cultivares 'IACSP94-2094' e 'IACSP97-7065' ( $1^{\circ}$ experimento). As barras indicam o erro padrão para três repetições biológicas

\subsection{6 $\gamma$-glutamilcisteína sintetase (GCS) e glutationa sintetase (GS)}

Durante a análise de expressão gênica foram investigados dois genes, sendo cada um deles codificador de uma enzima chave na biossíntese de glutationa reduzida (GSH), a

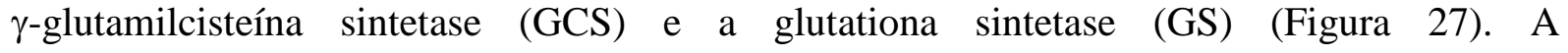
'IACSP94-2094' considerada tolerante apresentou acúmulo de transcritos para $G S$ apenas aos 14 DAT (Figura $27 \mathrm{C}$ ), enquanto que para o $G C S$ não houve aumento da expressão em nenhum período amostrado (Figura $27 \mathrm{~A}$ ). Com relação à expressão do $G C S$, houve um pequeno acúmulo de transcritos na cultivar sensível ('IACSP97-7065') no período de 
7 e 28 DAT (Figura 27 B), e com relação à expressão do $G S$ foi possível observar aumento no nível de transcritos somente aos 21 DAT (Figura 27 D).
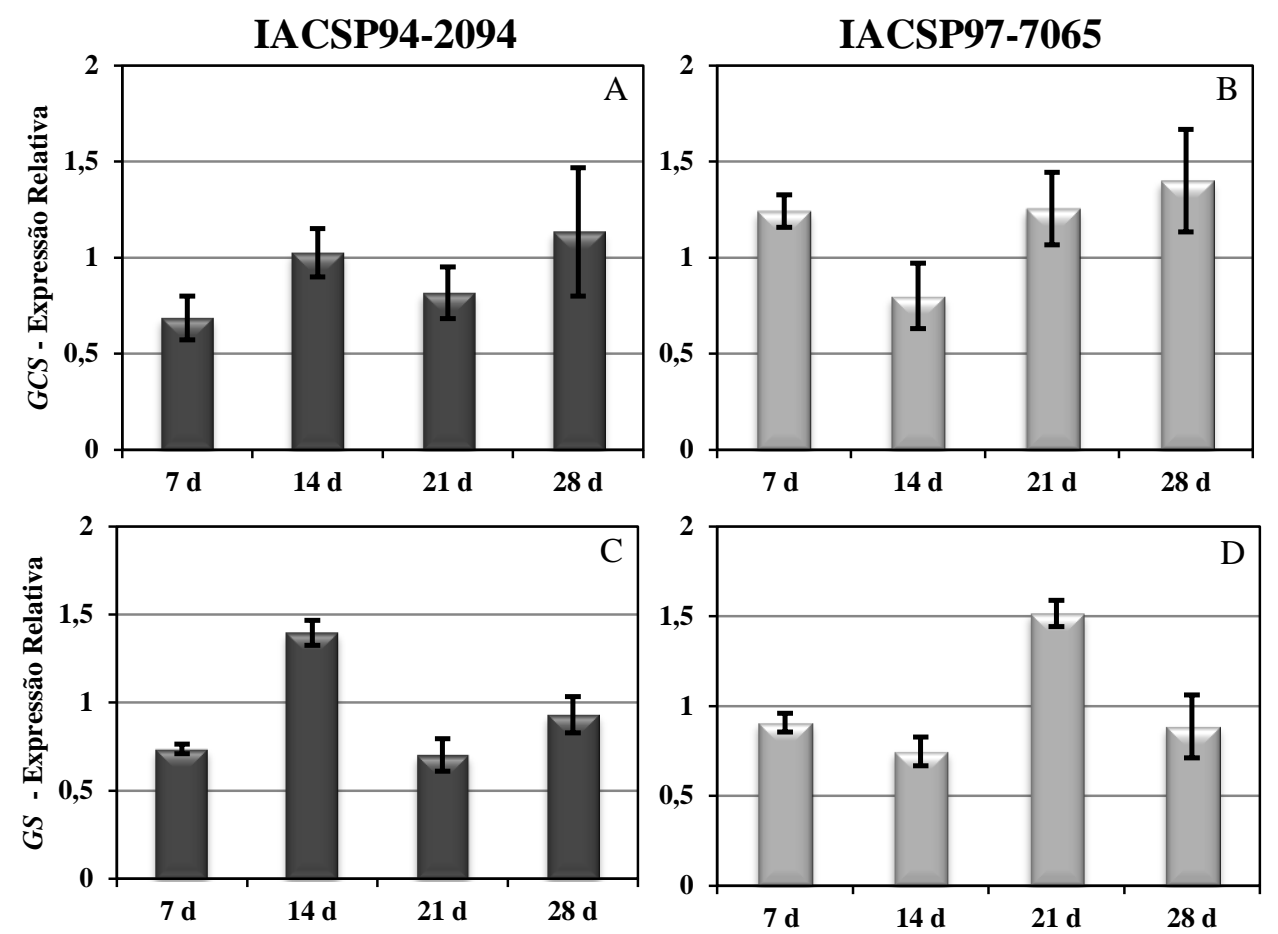

Figura 27 - Perfil de expressão relativa dos genes GCS e GS no tratamento de seca em relação ao controle irrigado para as cultivares 'IACSP94-2094' e 'IACSP97-7065' ( $1^{\circ}$ experimento). As barras indicam o erro padrão para três repetições biológicas

\subsubsection{Glutationa S-transferase (GST)}

A GST enzima que atua na conjugação de GSH com moléculas xenobióticas, revelou no ensaio de atividade específica por expectrofotometria baixa atividade durante todo o período de seca, independente da cultivar analisada, podendo ser destacado o primeiro período amostrado (7 DAT), onde, similarmente ao ocorrido para SOD, APX e CAT, a atividade específica da GST foi maior nas plantas submetidas à seca quando comparadas as plantas controle em ambas cultivares. Além do aumento de atividade no período inicial de seca, também houve aumento na atividade de GST aos 21 DAT em ambas cultivares (Figura 28). 

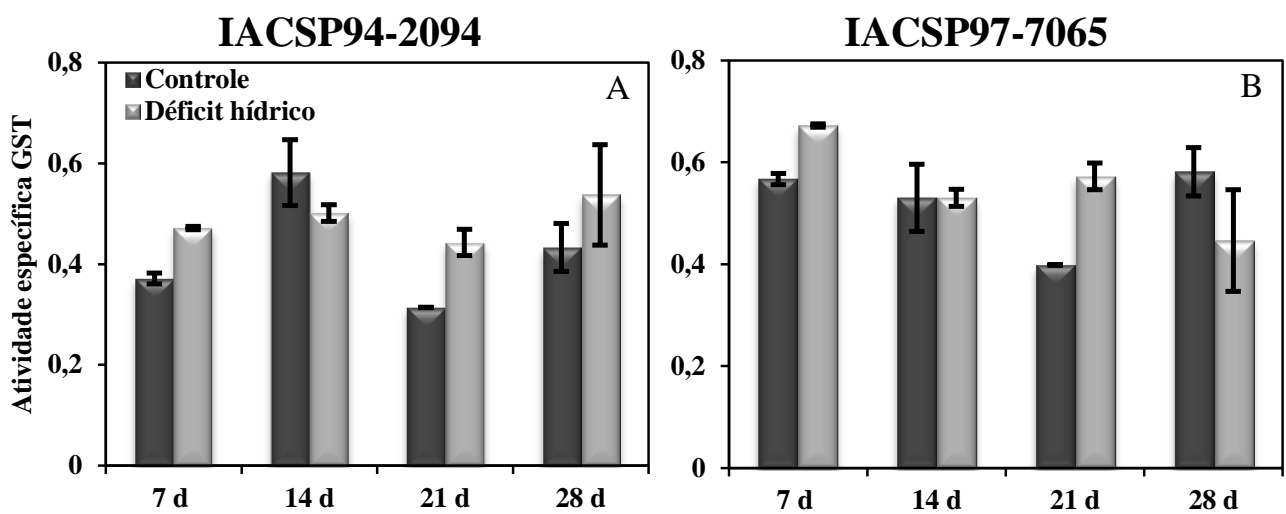

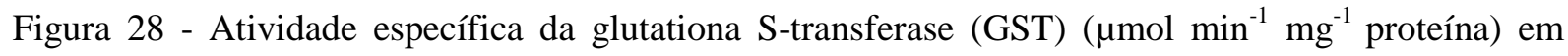
folha de cana-de-açúcar das cultivares 'IACSP94-2094' e 'IACSP97-7065', 7, 14, 21 e 28 dias após a suspensão da água ( $1^{\circ}$ experimento). As barras indicam o erro padrão para três repetições biológicas

Para a análise de quantificação dos níveis de transcritos, foram investigados os genes que codificam para as isoformas GSTF3, GSTF4, GSTT13 e GSTT17. Nesta análise, a GSTF4 apresentou acúmulo de transcritos para a cultivar tolerante ('IACSP94-2094') no período de 7 DAT em relação ao controle (1) não havendo, entretanto, diferenças significativas de 14 até 28 DAT (Figura 29 C). Para GSTT17 aos 14 e 21 DAT também apresentou acúmulo de transcritos (Figura 29 G). Nenhuma isoforma mostrou aumento significativo de expressão gênica para a cultivar sensível ('IACSP97-7065') (Figura 29 B, D, F, H). 

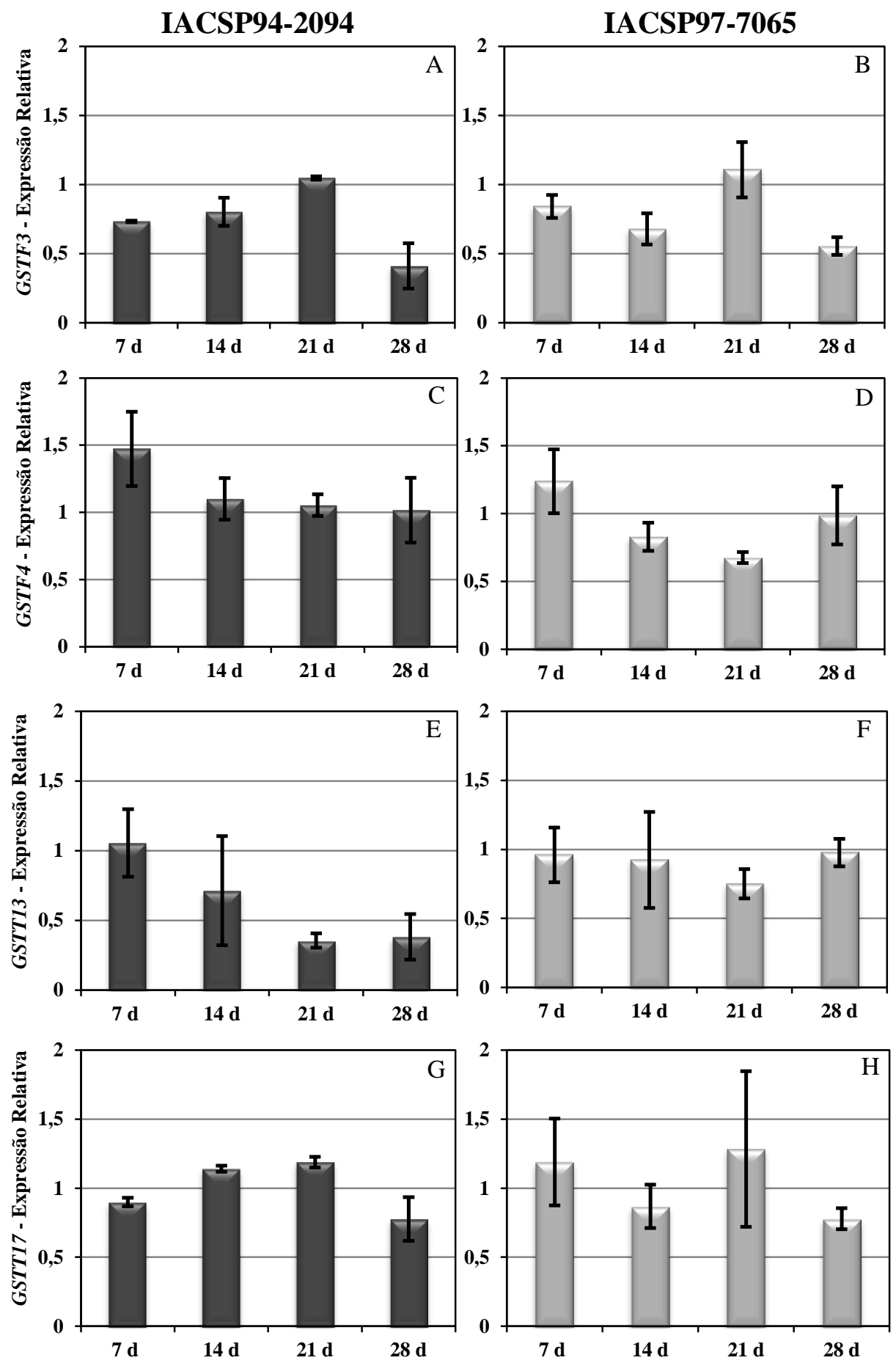

Figura 29 - Perfil de expressão relativa dos genes GSTF3, GSTF4, GSTT13 e GSTT17 no tratamento de seca em relação ao controle irrigado para as cultivares 'IACSP94-2094' e 'IACSP97-7065' ( $1^{\circ}$ experimento). As barras indicam o erro padrão para três repetições biológicas

\subsection{Concentração de prolina}

A prolina pode ser utilizada como indicador metabólico de resposta ao estresse hídrico, pois pode atuar como osmoregulador na célula. No segundo experimento foi avaliado 
o nível deste aminoácido em todos os períodos amostrais, sendo que foi obtido incrementos no seu conteúdo apenas para cultivar sensível ('IACSP97-7065') durante os períodos de 7 e 14 DAT de suspensão da água (Figura 30).
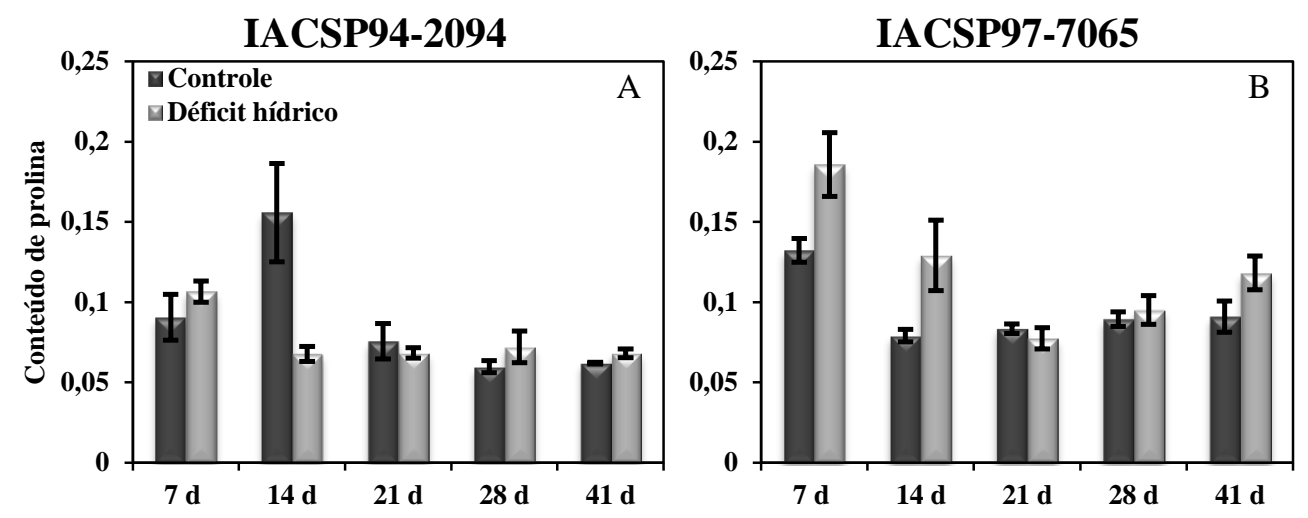

Figura 30 - Conteúdo de prolina ( $\mu \mathrm{mol} / \mathrm{g}$ MF) em folha de cana-de-açúcar para as cultivares 'IACSP94-2094' e 'IACSP97-7065', 7, 14, 21, 28 e 41 dias após a suspensão da água ( $2^{\circ}$ experimento). As barras indicam o erro padrão para três repetições biológicas

\subsection{Concentração de compostos fenólicos totais}

Compostos fenólicos podem atuar como antioxidantes, sendo assim, no segundo experimento foram analisados dois períodos, um referente ao estresse inicial (14 DAT) e outro ao estresse máximo (41 DAT).

A cultivar tolerante ('IACSP94-2094') não apresentou incrementos no conteúdo de compostos fenólicos totais em nenhum período analisado. Entretanto, a cultivar sensível ('IACSP97-7065') demonstrou incrementos deste composto no período de seca máxima (Figura 31).
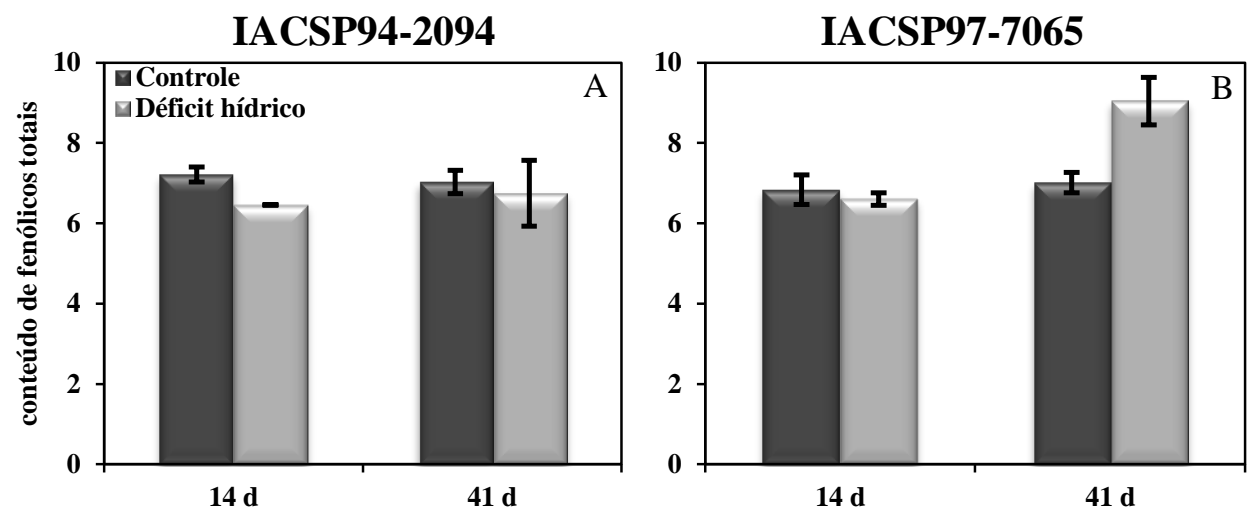

Figura 31 - Conteúdo de compostos fenólicos totais (g ácido tânico/kg matéria seca) em folha de canade-açúcar para as cultivares 'IACSP94-2094' e 'IACSP97-7065', 14 e 41 dias após a suspensão da água $\left(2^{\circ}\right.$ experimento). As barras indicam o erro padrão para três repetições biológicas 


\section{DISCUSSÃO}

Durante a condução do primeiro experimento foi possível observar diferenças visuais drásticas entre os tratamentos controle e seca, e também diferenças entre o comportamento das cultivares nos dois tratamentos, no que diz respeito à altura da planta e à presença de folhas verdes e folhas senescentes (Figura 3 e 4), sendo a cultivar 'IACSP97-7065' fenotipicamente menos afetada. As análises de parâmetros fisiológicos demostraram que a assimilação de $\mathrm{CO}_{2}(A)$ e condutância estomática $\left(g_{S}\right)$, foram seriamente reduzidas pela falta de água na cultivar 'IACSP94-2094'. Já para a cultivar 'IACSP97-7065', houve diferença entre os tratamentos, mas não houve diferenças significativas nos valores absolutos dos parâmetros em seca. Este resultado pode estar relacionado ao fato das plantas estarem em estádio de desenvolvimento, o que levaria ao aumento da fotossíntese e condutância estomática resultante do aumento da demanda energética da planta. Dessa forma, as plantas que estavam sob déficit hídrico não conseguiram acompanhar as plantas controle no aumento destes parâmetros devido à falta de água.

Surpreendentemente, os dados de análise fenotípica e trocas gasosas mostraram que as plantas da cultivar 'IACSP97-7065' não foram tão afetadas pelo déficit hídrico quanto esperado. Portanto, considerando que um dos maiores problemas encontrados em estudos relacionados a estresses abióticos em plantas é a determinação precisa do status de estresse, foi realizado um segundo experimento sob as mesmas condições, a fim de avaliar outros parâmetros fisiológicos adicionais, confirmando as condições hídricas pela avaliação do potencial hídrico da folha, do solo e CRA.

No segundo experimento, o potencial hídrico e o conteúdo relativo de água (CRA) das folhas indicaram que as plantas das cultivares 'IACSP94-2094' e 'IACSP97-7065' submetidas ao déficit hídrico sofreram desidratação ao longo do período experimental, porém de forma distinta. Na cultivar tolerante ('IACSP94-2094') ambos os parâmetros demonstraram que o teor de água da folha diminuiu mais rapidamente do que na cultivar sensível ('IACSP97-7065') (Figuras 6 e 7). O potencial hídrico do solo (Figura 8) corroborou as avaliações do potencial de água das folhas, evidenciando que a cultivar 'IACSP97-7065', demora mais para entrar em estresse por déficit hídrico, enquanto que para a cultivar 'IACSP94-2094', a diminuição do potencial hídrico do solo ocorreu durante a fase inicial da suspensão de água. Esses resultados sugerem que há diferenças de crescimento entre as cultivares. Ambos os experimentos foram observadas diferenças visuais para tamanho e 
número de folhas, que foram corroboradas pelos dados de massa seca das plantas, indicando que a massa seca da cultivar tolerante foi aproximadamente o dobro da obtida com a cultivar sensível (Figura 9).

De acordo com Lawlor e Cornic (2002), a assimilação de $\mathrm{CO}_{2}$ diminui à medida que o teor relativo de água e o potencial hídrico da folha diminuem. A deficiência hídrica no solo afeta as trocas gasosas foliares através de decréscimos na transpiração e na fotossíntese, sendo ambas reguladas pela condutância estomática (CORNIC, 2000), decrescendo em plantas submetidas ao estresse por seca como tentativa de manter a hidratação da planta (INMAN-BAMBER; SMITH, 2005). A desidratação indicada tanto pelo potencial hídrico da folha quanto pelo CRA está de acordo com as reduções nas trocas gasosas percebidas para a cultivar 'IACSP94-2094'. A assimilação de $\mathrm{CO}_{2}(A)$, condutância estomática ( $\left.g_{S}\right)$, transpiração $(E)$ foram significantemente menores nas plantas sob restrição hídrica do que nas plantas controle (Figura 10). Essa redução nos valores de $A, g_{S}$ e $E$ em plantas sob déficit hídrico, também foi observado em outros trabalhos com cana-de-açúcar (RIBEIRO et al., 2013; BELLOTI, 2012). Já as trocas gasosas na cultivar 'IACSP97-7065' apresentaram comportamento similar ao primeiro experimento, pois houve diferença entre os tratamentos. Entretanto, não houve diferenças significativas nos valores absolutos dos parâmetros em seca, sugerindo que as plantas foram pouco afetadas sob déficit hídrico, diferentemente dos valores absolutos para a cultivar 'IACSP94-2094'.

Sob condições de estresse a taxa fotossintética diminui e a planta precisa desviar o excesso de luz absorvida para outros processos, como dissipação de calor e emissão de fluorescência para proteger o aparato fotossintético. Portanto, as maneiras de dissipação de energia estão interligadas, e consequentemente, a eficiência fotoquímica do fotossistema II pode ser monitorada por medições da fluorescência (OSMOND; SCHWARTZ; GUNNING, 1999). A eficiência quântica efetiva $\left(\Delta F / F_{m}{ }^{\prime}\right)$ do fotossistema II e a taxa de transporte aparente de elétrons (ETR) representam os elétrons transportados que chegam ao final da cadeia transportadora da fase fotoquímica para formar ATP e NADPH, que seriam consumidos na etapa de carboxilação na fotossíntese (KONRAD et al., 2005). Os resultados obtidos neste trabalho mostraram que o déficit hídrico provocou diminuição na eficiência quântica efetiva $\left(\Delta F / F_{m}{ }^{\prime}\right)$ (Figura $11 \mathrm{C}$ ) e na taxa de transporte aparente de elétrons $(E T R)$ (Figura 11 E) em plantas da cultivar tolerante ('IACSP94-2094'), corroborando com os dados obtido para as trocas gasosas, o que confirmou o status de estresse apresentado pela cultivar diante da seca. Entretanto, na cultivar 'IACSP97-7065' a diferença entre os tratamentos para os parâmetros $\Delta F / F_{m}$ ' e $E T R$ não foi tão acentuada quando na 'IACSP94-2094', indicando 
que essa cultivar foi pouco afetada pelas condições impostas (Figura 11 D e F). Com relação ao coeficiente de extinção fotoquímico $(q P)$, que indica a proporção dos centros de reação do PSII que estão abertos para receber a energia luminosa que chega na planta, no geral também sofreu redução nas plantas da 'IACSP94-2094' sob déficit hídrico, entretanto, aos 41 DAT somente uma tendência a redução, mas sem diferença significativa, sugerindo uma queda no dreno da energia para a fixação do $\mathrm{CO}_{2}$ (Figura $11 \mathrm{G}$ ), enquanto que, na cultivar 'IACSP97-7065' houve uma pequena redução nas plantas sob seca comparada com as plantas controle, mas também sem diferença significativa aos 41 DAT, mostrando mais uma vez que essa cultivar não foi tão afetada quanto a cultivar 'IACSP94-2094' (Figura 11 H). A eficiência quântica potencial $\left(F_{v} / F_{m}\right)$ do fotossistema II, que é uma estimativa da eficiência quântica máxima da atividade fotoquímica do PSII, sofreu redução na relação $F_{\downarrow} / F_{m}$ somente nas folhas das plantas da cultivar tolerante ('IACSP94-2094') submetidas ao déficit hídrico (Figura 11 A e B), portanto, as plantas sob seca podem ter sofrido algum dano no aparato fotossintético durante esse período devido a redução da razão $F_{\downarrow} / F_{m}$ quando comparada com as plantas controle. A destruição do centro de reação tem como consequência os baixos valores de rendimento quântico da fotoquímica, sendo que este comportamento também foi observado por Molinari et al. (2007) com plantas de cana-de-açúcar submetidas ao estresse hídrico, que apresentaram quedas no redimento quântico da fotoquímica do fotossistema em decorrência dos aumentos das taxas de peroxidação lipídica.

Quando as folhas das plantas sofrem alterações na etapa fotoquímica o excesso de energia no PSII pode resultar na dissipação desta energia para o oxigênio, gerando as espécies reativas de oxigênio (ROS), que pode desencadear danos oxidativos nas membranas dos tilacóides dos cloroplastos onde estão localizados os centros de reação do PSII e proteína D1, resultando na oxidação destes compostos sob condições de estresse hídrico (PELTZER; DREYER; POLLE, 2002; SCHELLER; HALDRUP, 2005).

No presente trabalho também foi investigado o nível de peroxidação lipídica de membranas, por meio do conteúdo de MDA, que é um produto da peroxidação de ácidos graxos poli-insaturados, processo mediado pelas ROS, indicando a ocorrência do estresse oxidativo (MITTLER, 2002; ILANGOVAN et al., 2006). Sob déficit hídrico, ocorreu peroxidação lipídica em todos os períodos amostrais na cultivar tolerante ('IACSP94-2094'), com exceção de 14 DAT (Figura 29 A). Em geral, o grau de peroxidação lipídica foi o mesmo em todos os períodos analisados, sugerindo que a cultivar tolerante conseguiu metabolizar as ROS, de modo que, não aumentou a peroxidação lipídica sob máximo déficit hídrico 
(41 DAT). Por outro lado, na cultivar sensível ('IACSP97-7065'), a peroxidação lipídica ocorreu somente no último período analisado (41 DAT) (Figura 29 B). De acordo com outros trabalhos, esse comportamento era esperado, pois sob déficit hídrico tem sido verificado aumento significativo da taxa de peroxidacão lipídica (MOLINARI et al., 2007; TATAR; GEVREK, 2008). Cia et al. (2012) também verificou peroxidação lipídica em cultivares de cana-de-açúcar contrastantes em resposta a seca, contudo, as cultivares sensíveis (SP90-3414 e SP90-1638) a seca exibiram um aumento considerável no conteúdo de MDA antes das cultivares tolerantes (SP83-2847 e SP83-5073), mas sob máximo déficit hídrico houve aumento no conteúdo de MDA para todas as cultivares.

Os dados obtidos para peroxidação lipídica sugerem que a cultivar sensível ('IACSP97-7065') não estava sob o mesmo nível de estresse da cultivar tolerante ('IACSP94-2094'), como anteriormente já foi detectado, estando de acordo os dados obtidos de potencial hídrico da folha, fotossíntese e rendimento fotoquímico. Além disso, é importante evidenciar que no período de máximo déficit hídrico as cultivares 'IACSP94-2094' e 'IACSP97-7065' estavam praticamente com o mesmo nível de peroxidação lipídica, sugerindo que, se a cultivar sensível estivesse em desidratação no mesmo período que a cultivar 'IACSP94-2094', seria possível que a peroxidação lipídica atingisse valores maiores nesta cultivar.

A produção de ROS é afetada por fatores ambientais e fisiológicos, sendo que a taxa de aumento de ROS ocorre quando a intesidade de fótons é superior ao necessário para a assimilação de $\mathrm{CO}_{2}$ (ASADA, 2006), sendo este potencialmente prejudicial para o aparato fotossintético. Portanto, a eliminação de ROS é necessária para proteção das biomoléculas. Dessa forma, o mecanismo de desintoxicação de ROS constitui a primeira linha de defesa contra os efeitos prejudiciais do estresse oxidativo (GRATÃO et al., 2005). A capacidade da planta de eliminar ROS está ligada a produção de diferentes tipos de antioxidantes, envolvendo os sistemas de defesa enzimáticos e não enzimáticos (NOCTOR; FOYER, 1998).

A atividade específica das enzimas chaves do sistema antioxidante que fazem parte do ciclo ascorbato-glutationa (Figura 1), como ascorbato peroxidase (APX) e glutationa redutase (GR) e outras, tais como superóxido dismutase (SOD), catalase (CAT) e glutationa S-transferase (GST), foram avaliadas na condição de déficit hídrico.

A primeira enzima estudada foi a SOD, enzima responsável por dismutar o radical superóxido $\left(\mathrm{O}_{2}{ }^{\circ}\right)$ em peróxido de hidrogênio $\left(\mathrm{H}_{2} \mathrm{O}_{2}\right)$ (GILL; TUTEJA, 2010). O superóxido produzido em excesso em decorrência do estresse induzido pela seca é altamente reativo podendo rapidamente ser convertido ao radical hidroxila $\left({ }^{\circ} \mathrm{OH}\right)$, o mais danoso dos radicais 
produzidos, com capacidade de induzir mutações, alterações deletérias no metabolismo primário e secundário, levando quase sempre à morte celular e consequentemente a morte da planta (VRANOVA et al., 2002). Portanto, a dismutação do superóxido à peróxido de hidrogênio é o primeiro passo para evitar a formação do radical hidroxila.

No período de máximo déficit hídrico somente a cultivar 'IACSP94-2094' respondeu com aumento da atividade da SOD (Figura 12). Este resultado pode ser indicativo de que a cultivar 'IACSP94-2094' foi efetiva na metabolização do radical superóxido no período de seca, podendo este fato, estar ligado a sua maior tolerância. De acordo com Basu et al. (2010), o aumento ou mesmo a manutenção da atividade da SOD está associado a tolerância, enquanto a sensibilidade ao déficit hídrico está associado a redução da atividade desta enzima. Portanto, este pode ser um indicativo de que a cultivar 'IACSP97-7065' não atingiu o mesmo nível de estresse que a cultivar 'IACSP94-2094', uma vez que, no período de estresse máximo (28 DAT) a 'IACSP97-7065' manteve a atividade da SOD igual ao das plantas controle, porém com uma tendência de redução da atividade no período analisado, o que pode indicar a sua sensibilidade ao estresse por seca.

Existem três isoformas da SOD, as quais são classificadas de acordo com seus cofatores: $\mathrm{Cu} / \mathrm{Zn}-\mathrm{SOD}, \mathrm{Mn}-\mathrm{SOD}$ e Fe-SOD. (FERREIRA et al., 2002). Neste trabalho, as três isoformas foram encontradas em PAGE nativo em ambas as cultivares, entretanto, o número de isoformas da SOD variou em função da cultivar, sendo encontrado na cultivar tolerante ('IACSP94-2094') um maior número de isoformas (sete bandas) envolvidas na resposta ao estresse oxidativo desencadeado pela seca, do que na cultivar sensível ('IACSP97-7065') (quatro bandas) (Figuras 14 e 15), sendo que, entre os três tipos de isoformas da SOD, a Fe-SOD foi a mais ativa em ambas as cultivares. Dessa maneira, na cultivar tolerante foram caracterizadas quatro isoformas da Fe-SOD, sendo estas encontradas usualmente nos cloroplastos (ALSCHER; ERTURK; HEATH, 2002), o que pode explicar sua maior atuação no combate ao estresse oxidativo. O presente resultado diverge do encontrado por Cia et al. (2012), que analisando quatro cultivares de cana-de-açúcar não observou Fe-SOD em nenhuma cultivar, somente isoformas Mn-SOD e Cu/Zn-SOD, sugerindo que o perfil de isoformas pode ser característica de cada cultivar. Outro estudo realizado com cana-de-açúcar sob estresse por metal pesado encontrou somente isoformas de $\mathrm{Cu} / \mathrm{Zn}-\mathrm{SOD}$ (FORNAZIER et al., 2002a). Plantas trangênicas de arroz com super-expressão de Mn-SOD apresentaram maior tolerância à seca (WANG et al., 2005). Entretanto, plantas de tabaco com super-expressão Fe-SOD nos cloroplastos adquiriram tolerância contra o estresse oxidativo 
induzido pelo herbicida Paraquat (VAN CAMP et al., 1996). Portanto, as cultivares estudadas neste trabalho, 'IACSP94-2094' e 'IACSP97-7065', unem o poder de resposta das três isoformas da SOD ao estresse oxidativo, sendo a cultivar tolerante a mais robusta nesta resposta. A expressão de genes referentes as isoformas da SOD mostraram acúmulo de transcritos para a Mn-SOD (SOD 1.1) e Cu/Zn-SOD (SOD 2.1.1) na cultivar tolerante. Na cultivar sensível os genes que tiveram indução da expressão foram Mn-SOD (SOD 1.1) e $\mathrm{Cu} / \mathrm{Zn}-\mathrm{SOD}$ (SOD 1.2) (Figura 16 A, B, D, E), sendo que, para ambas as cultivares o aumento da expressão pode estar ligado ao aumento da atividade específica na cultivar tolerante ('IACSP94-2094') e na manutenção do mesmo nível da SOD na cultivar sensível ('IACSP97-7065').

Após a dismutação do superóxido em peróxido de hidrogênio pela SOD existe a necessidade da atuação de peroxidases para a conversão de $\mathrm{H}_{2} \mathrm{O}_{2}$ em produtos não tóxicos. A primeira enzima a atuar na conversão do peróxido de hidrogênio em água é a APX, que possui a maior afinidade ao substrato (AHMAD et al., 2010). Nos resultados obtidos neste trabalho, foi observado que sob condições de estresse hídrico, a atividade da APX na cultivar 'IACSP94-2094' apresentou aumento muito expressivo em relação as plantas controle no período de máximo déficit hídrico (Figura 17 A), o que indica que sob estresse máximo a cultivar 'IACSP94-2094' foi capaz de metabolizar o peróxido de hidrogênio.

As enzimas SOD e APX podem ser a primeira linha de defesa durante o processo de aclimatação à seca, pois são enzimas essenciais para controlar o estresse oxidativo (LU; DENG; KWAK, 2010). Kwon et al. (2002) propõem que a super-expressão de SOD e APX no cloroplasto seria capaz de eliminar rapidamente o radical superóxido e o peróxido de hidrogênio do local de produção, antes da sua interação com moléculas alvo, mostrando o efeito aditivo na atividade das duas enzimas para a melhor eliminação de ROS. Este efeito aditivo também foi observado em plantas de batata doce, onde a maior expressão de $\mathrm{Cu} / \mathrm{Zn}$-SOD e APX conferiram maior tolerância ao estresse hídrico (LU; DENG; KWAK, 2010). Nos resultados deste trabalho, também foi observado o efeito aditivo para a cultivar tolerante ('IACSP94-2094'), que sob máximo déficit hídrico apresentou aumento da atividade das duas enzimas.

A expressão gênica relativa das isoformas da APX não apresentou acúmulo de transcritos para nenhuma isoforma analisada para a cultivar 'IACSP94-2094' (Figura 18 A, C, E). A medida de atividade específica da APX em extrato de proteína total integra as diferentes isoformas de APX, entretanto, as expressões dos quatros genes analisados neste trabalho podem estar representando somente uma parte das isoformas 
existentes na folha da cultivar tolerante, podendo ser uma justificativa para os resultados negativos obtidos por meio das análises de expressão gênica para essa enzima.

A CAT, enzima que atua auxiliando o ciclo ascorbato-glutationa, deve atuar na desintoxicação de peróxido de hidrogênio (AHMAD et al., 2010) que não foi eliminado pela APX. Entretanto, neste trabalho, a atividade da CAT não mostrou resposta quando as plantas estavam submetidas ao máximo déficit hídrico em ambas as cultivares (Figura 19 A, B). Para a CAT somente a cultivar 'IACSP94-2094' apresentou acúmulo de transcritos dos genes CAT 1.1 e CAT 3.1 aos 28 DAT, podendo ainda não terem refletido nos valores de atividade enzimática até o momento da análise (Figura $21 \mathrm{~A}, \mathrm{E}$ ). Na atividade em PAGE nativo somente uma banda de atividade de catalase foi observado para ambas as cultivares em cada período analisado (Figura 20). Por outro lado, na cultivar sensível ('IACSP97-7065') a isoforma que estava atuando nas plantas aos 7 DAT não era a mesma isoforma que estava atuando aos 28 DAT, enquanto que, a isoforma presente sob máximo déficit hídrico foi a mesma em ambas as cultivares. Resultado similar foi observado por Fornazier et al. (2002a), que sob estresse por metal pesado como o cádmio, foi observado somente uma banda para a CAT em cana-de-açúcar, além do decréscimo na atividade da CAT nas doses mais elevadas do metal. Os resultados sugerem que dentre as peroxidases avaliadas, a APX é mais efetiva sob condições de estresse em cana-de-açúcar.

Outra enzima importante do ciclo ascorbato-glutationa é a GR responsável por manter os níveis de glutationa reduzida (GSH), poderoso antioxidante não enzimático e substrato para a conjugação de xenobióticos nas plantas pela enzima GST (NOCTOR et al., 2002). Além disso, a GR também é responsável pela oxidação do NADPH para a regeneração do ascorbato no ciclo (Figura 1).

O resultado de expressão de três genes referentes à isoformas de GR mostrou acúmulo de transcrito somente para GR 2 aos 28 DAT na cultivar 'IACSP94-2094' (Figura 25 C). Juntamente com o aumento da atividade da APX, a atividade da GR teve um aumento significativo sob máximo déficit hídrico na cultivar tolerante (Figura 23 A). Este resultado sugere que o ciclo ascorbato-glutationa estava ativo durante a seca máxima e, portanto, neste período, o sistema de regeneração do ascorbato foi reforçado, como indicado pela elevada atividade de GR, além de manter os níveis de GSH. Uma rota adicional para a disponibilidade de ascorbato na célula seria a biossíntese (PINTO; TOMMASI; GARA, 2000). Deste modo, acredita-se que a biossíntese desta molécula ocorreria devido a insuficiente capacidade das enzimas de reciclagem. Entretanto, a GR, uma das enzimas envolvidas nessa rota de 
regeneração do ascorbato estava muito ativa para manter o bom funcionamento do ciclo ascorbato-glutationa na cultivar tolerante ('IACSP94-2094') sob seca, sendo que o eficiente funcionamento do ciclo permitiria as plantas suportarem o estresse oxidativo (MAEVSKAYA; NIKOLAEVA, 2013).

O resultado de aumento de atividade da GR obtido neste trabalho está de acordo com o observado por Bartoli et al. (1999) em folha de trigo sob condições de estresse. Fornazier et al. (2002a) também observaram que o aumento na atividade da GR foi o principal mecanismo de resposta em cana-de-açúcar expostas ao cádmio. Além disso, o nível elevado de GR pode ser capaz de aumentar a proporção de $\mathrm{NADP}^{+} / \mathrm{NADPH}$, assim há maior disponibilidade de $\mathrm{NADP}^{+}$para aceitar elétrons da cadeia transportadora de elétrons da fotossíntese (BAISAK et al., 1994). Diversos estudos mostram que ocorrem mudanças nas atividades das enzimas antioxidantes de plantas em resposta à seca. Lascano et al. (2001) verificou aumento na atividade da SOD, APX e GR em genótipos tolerantes de trigo, a qual foi mantida ou reduzida em genótipos sensíveis em resposta ao déficit hídrico.

A glutationa (GSH) é um dos antioxidantes não enzimáticos mais importantes relacionados com a eliminação de ROS na célula, além de atuar como substrato em reações enzimáticas, como a regeneração do ascorbato, desintoxicação de $\mathrm{H}_{2} \mathrm{O}_{2}$ pela glutationa peroxidase (GPX) e como substrato para a conjugação de xenobióticos realizada pela glutationa S-transferase (GST) (YU, 1994; MARRS, 1996). Genes que codificam duas enzimas chaves na biossíntese de glutationa reduzida (GSH) (Figura 2), a $\gamma$-glutamilcisteína sintetase (GCS) e a glutationa sintetase (GS) foram consideradas por análise quantitativa de transcritos. A cultivar tolerante ('IACSP94-2094') apresentou acúmulo de transcritos do gene $G S$, o que poderia indicar que essa cultivar estaria aumentando a biossíntese de GSH. Entretanto, não foi percebida a expressão do gene $G C S$, que se refere a primeira enzima da via de biossíntese de GSH. Porém, a expressão deste gene poderia ter acontecido em algum período não avaliado (Figura 26 A, C). Já a cultivar sensível ('IACSP97-7065') apresentou acúmulo de transcritos para ambos os genes $(G C S$ e $G S)$, portanto, tanto a cultivar tolerante quanto a cultivar sensível poderiam estar sintetizando novas moléculas de GSH (Figura 26 B, D). Entretanto, essa evidência deveria se confirmar por dados de atividade da enzima da GCS, pois de acordo com Noctor et al. (2002) a biossíntese da glutationa (GSH) em plantas é controlada pela atividade da $\gamma$-glutamilcisteína sintetase (GCS) e disponibilidade de cisteína. Contudo, a atividade da GR para a cultivar tolerante ('IACSP94-2094') demonstra que somente ela estava intensificando o processo de reciclagem GSH para o controle de ROS. 
A última enzima analisada foi a GST, enzima que pode atuar como peroxidase, denominada de GPX, auxiliando o ciclo ascorbato-glutationa na desintoxicação de peróxido de hidrogênio, além de atuar na conjugação de glutationa reduzida (GSH) com moléculas xenobióticas (GILL; TUTEJA, 2010). A GST não revelou atividade detectável e acúmulo de transcritos sob máximo déficit hídrico em ambas as cultivares analisadas. Da mesma forma, para GPX, nenhum dos três genes analisados apresentaram acúmulo de transcritos em ambas as cultivares (Figura 22). Estes resultados sugerem que tanto a GST quanto a GPX não foram importantes no controle do estresse oxidativo desencadeado pela seca em cana-de-açúcar, ou no caso da GPX, outras isoformas poderiam estar atuando na resposta ao estresse hídrico.

Em adição ao estudo dos efeitos da seca nas enzimas do sistema antioxidante, também foi analisado o conteúdo de prolina. O acúmulo deste aminoácido é uma estratégia da planta para manutenção do ajuste osmótico, assim o potencial osmótico no interior da célula é reduzido pelo acúmulo de solutos compatíveis no citoplasma. Dessa forma, a prolina desempenha um papel importante na regulação osmótica, entretanto, além deste papel, a prolina também pode ser importante contra danos oxidativos, pela capacidade de eliminar ROS da célula ou ativando mecanismo de defesa antioxidante, além de ser associada à tolerância à seca (CHEN; DICKMAN, 2005; ALIA; MOHANTY; MATYSIK, 2001; MOLINARI et al., 2007). Os resultados indicaram que a prolina não desempenha um papel importante na tolerância ao déficit hídrico na 'IACSP94-2094' (Figura 30 A), pois sob a influência da seca, o conteúdo de prolina permaneceu praticamente igual ao controle sob alto e baixo potencial hídrico, indicando que essa não seria uma estratégia usada pelo 'IACSP94-2094' para tolerar o déficit hídrico. Resultado similares foram obtidos por Ribeiro et al. (2013), que estudando a mesma cultivar tolerante ('IACSP94-2094') não encontrou incrementos no conteúdo de prolina em resposta a seca. Em cana-de-açúcar e em outras culturas o acúmulo de prolina tem apresentado variações quantitativas com relação a cultivar analisada. Alguns trabalhos mostram que cultivares tolerantes em resposta ao déficit hídrico apresentaram acúmulo no conteúdo de prolina (FUMIS; PEDRAS, 2002; QUEIROZ et al., 2008). Cia et al. (2012) detectaram elevados níveis de prolina em cultivares de cana-deaçúcar sensíveis a seca em relação as cultivares tolerantes aos 10 DAT, e aos 20 DAT o conteúdo de prolina foi semelhante entre as cultivares tolerantes e sensíveis a seca.

Enquanto os metabólitos primários são substâncias envolvidas no crescimento e desenvolvimento vegetal, os metabólitos secundários estão associados a estratégias de defesa das plantas (TAIZ; ZEIGER, 2009). Os metabólitos secundários podem ser classificados em 
três grupos: terpenos, compostos fenólicos e compostos nitrogenados (TAIZ; ZEIGER, 2009). No grupo dos compostos fenólicos, os flavonóides e os ácidos fenólicos são considerados os antioxidantes fenólicos (BROINIZI et al., 2007).

Os compostos fenólicos agem como antioxidantes, devido às propriedades redutoras e estrutura química (LÓPEZ-VÉLEZ; MARTÍNEZ-MARTÍNEZ; DEL VALLE-RIBES, 2003). O aumento no conteúdo dos compostos fenólicos indica que esta é provavelmente uma resposta contra a geração do ROS desencadeada pelo estresse hídrico e salino (GÓMEZCARAVACA et al., 2012; BETTAIEB, et al., 2011). A determinação dos níveis de compostos fenólicos totais foi investigada durante o estresse inicial e estresse máximo, sendo que na cultivar tolerante ('IACSP94-2094'), a produção de fenólicos em resposta ao estresse oxidativo não parece ter sido uma estratégia adotada por essa cultivar (Figura $31 \mathrm{~A}$ ). Este resultado não está de acordo com o observado por Bhardwaj e Yadav (2012), que encontraram nível mais elevado de fenólicos em variedade tolerante, sugerindo a sua contribuição na adaptação da planta em condições de estresse hídrico. Entretanto, no período de máximo déficit hídrico na cultivar sensível ('IACSP97-7065') houve incremento no teor de compostos fenólicos (Figura 31 B), o que pode ser um mecanismo adotado por esta cultivar para superar os efeitos prejudiciais da seca, enquanto que, a cultivar tolerante utiliza de outras estratégias para o controle de ROS. Sendo assim, mecanismos como acúmulo de prolina e compostos fenólicos indicam ser estratégias auxiliares adotadas pela planta na resposta ao estresse hídrico.

Os dados apresentados neste trabalho sugerem que o mecanismo antioxidante enzimático foi induzido para o controle do estresse oxidativo desencadeado pela seca na cultivar tolerante ('IACSP94-2094'). Apesar dos dados mostrarem que a cultivar sensível ('IACSP97-7065') não atingiu o mesmo nível de estresse hídrico que a cultivar tolerante, pode-se afirmar que o perfil das isoformas das enzimas antioxidantes variou entre as cultivares, sendo que, o perfil diferenciado apresentado pela cultivar 'IACSP94-2094' pode colaborar para a sua tolerância ao estresse hídrico. 


\section{CONCLUSÕES}

O sistema antioxidante enzimático está envolvimento na resposta ao déficit hídrico em cana-de-açúcar, sendo a superóxido dismutase (SOD), a ascorbato peroxidase (APX) e a glutationa redutase (GR) as enzimas chave para o controle do estresse oxidativo desencadeado pela seca na cultivar tolerante ('IACSP94-2094').

A importância da variabilidade genética das cultivares com relação às isoformas das enzimas deve ser considerada na resposta do sistema antioxidante ao déficit hídrico. Destacando-se as isoformas $\mathrm{Fe}-\mathrm{SOD}$ e $\mathrm{Cu} / \mathrm{Zn}$-SOD presentes em maior número na cultivar 'IACSP94-2094'. 


\section{REFERÊNCIAS}

AHMAD, P.; JALEEL, C.A.; SALEM, M.A.; NABI, G.; SHARMA, S. Roles of enzymatic and nonenzymatic antioxidants in plants during abiotic stress. Critical Reviews in Biotechnology, Boca Raton, v. 30, p. 161-175, 2010.

ALIA, J.M.; MOHANTY, P.; MATYSIK, J. Effect of proline on the production of singlet oxygen. Amino Acids, Wien, v. 21, p. 195-200, 2001.

ALLAHVERDIEV, S.R.; MAVITUNA, M.; GANIEVA, R. Effects of salt stress and synthetic hormone polystimuline $\mathrm{K}$ on photosynthetic activity of Trianea bogotensis Karst. Turkish Journal of Botany, Ankara, Turkey, v. 22, p. 19-23, 1998.

ALSCHER, R.G.; ERTURK, N.; HEATH, L.S. Role of superoxide dismutases (SODs) in controlling oxidative stress in plants. Journal of Experimental Botany, Oxford, v. 53, p.1331-1341, 2002.

ANGELOVA, M.B.; PASHOVA, S.B.; SLOKOSKA, L.S. Comparison of antioxidant enzyme biosynthesis by free and immobilized Aspergillus nidulans cells. Enzyme and Microbial Technology, Surrey, v. 26, p.544-549, 2000.

ASADA, K. Production and scavenging of reactive oxygen species in chloroplasts and their functions. Plant Physiology, Rockville, v. 141, p. 391-396, 2006.

ASADA, K. The water-water cycle in chloroplasts: scavenging of reactive oxygens and dissipation of excess photons. Annual Review of Plant Physiology and Plant Molecular Biology, Palo Alto, v. 50, p. 601-639, 1999.

ASADA, K. Ascorbate peroxidase a hydrogen peroxide scavenging enzyme in plants. Physiologia Plantarum, Copenhagen v. 85, p. 235-241, 1992.

AZEVEDO, R.A.; CARVALHO, R.F.; CIA, M.C.; GRATÃO, P.L. Sugarcane under pressure: an overview of biochemical and physiological studies of abiotic stress. Tropical Plant Biology, New York, v. 4, p. 42-51, 2011.

AZEVEDO, R.A.; ALAS, R.M.; SMITH, R.J.; LEA, P.J. Response of antioxidant enzymes to transfer from elevated carbon dioxide to air and ozone fumigation, in leaves and roots of wildtype and catalase-deficient mutant of barley. Physiologia Plantarum, Copenhagen, v. 104, p. 280-292, 1998.

BAGNOLI, F.; DANTI, S.; MAGHERINR, V.; COZZA, R.; INNOCENTI, A.M.; RACCHI, M.L. Molecular cloning, characterization and expression of two catalase genes from peach. Functional Plant Biology, Victoria, v. 31, p. 349-357, 2004.

BAISAK, R.; RANA, D.; ACHARYA, P.B.B.; KAR, M. Alterations in the activities of active oxygen scavenging enzymes of wheat leaves subjected to water stress. Plant and Cell Physiology, Tokyo, v. 35, p. 489-495, 1994. 
BAKER, N.R.; ROSENQVIST, E. Applications of chlorophyll fluorescence can improve crop production strategies: an examination of future possibilities. Journal of Experimental Botany, Oxford, v. 55, p. 1607-1621, 2004.

BARONDEAU, D.P.; KASSMAN, C.J.; BRUNS, C.K.; TAINER, J.A.; GETZOFF, E.D. Nickel superoxide dismutase structure and mechanism. Protein Science, New York, v. 13, p. 192-431, 2004.

BARRS, H.D.; WEATHERLEY, P.E. A re-examination of the relative turgidity technique for estimating water deficit in leaves. Australian Journal of Biological Sciences, Melbourne, v. 15, p. 413-428, 1962.

BETTAIEB, I.; HAMROUNI-SELLAMI, I.; BOURGOU, S.; LIMAM, F.; MARZOUK, B. Drought effects on polyphenol composition and antioxidant activities in aerial parts of Salvia officinalis L. Acta Physiologiae Plantarum, Heidelberg, v. 33, p. 1103-1111, 2011.

BROINIZI, P.R.B.; ANDRADE-WARTHA, E.R.S.; SILVA, A.M.O.; NOVOA, A.J.V.; TORRES, R.P.; AZEREDO, H.M.C.; ALVES, R.E.; MANCINI-FILHO, J. Avaliação da atividade antioxidante dos compostos fenólicos naturalmente presentes em subprodutos do pseudofruto de caju (Anacardium occidentale L.). Ciência e Tecnologia de Alimentos, Campinas, v. 27, p. 902-908, 2007.

BARTOLI, C.G.; SIMONTACCHI, M.; TAMBUSSI, E.; BELTRANO, J.; MONTALDI, E.; PUNTARULO, S. Drought and watering-dependent oxidative stress: effect on antioxidant content in Triticum aestivum L. leaves. Journal of Experimental Botany, Oxford, v. 50, p. 375-383, 1999.

BASU, S.; ROYCHOUDHURY, A.; SAHA, P.P.; SENGUPTA, D.N. Differential antioxidative responses of indica rice cultivars to drought stress. Plant Growth Regulation, Dordrecht, v. 60, p.51-59, 2010.

BATES, L.S.; WALDREN, R.P.; TEARE, I.D. Rapid determination of free proline for water stress studies. Plant and Soil, Dordrecht, v. 39, p. 205-207, 1973.

BELLOTI, M. Mecanismo de descarboxilação da fotossíntese $\mathbf{C}_{4}$ e discriminação isotópica para seleção de genótipos do complexo Saccharum spp. tolerantes à seca. 2012. 89 p. Dissertação (Mestrado em Ciências) - Centro de Energia Nuclear na Agricultura, Universidade de São Paulo, Piracicaba, 2012.

BHARDWAJ, J.; YADAV, S.K. Comparative study on biochemical parameters and antioxidant enzymes in a drought tolerant and a sensitive variety of horsegram (Macrotyloma uniflorum) under drought stress. American Journal of Plant Physiology, New York, v. 7, p. 17-29, 2012.

BOWLER, C.; VAN MONTAGU, M.; INZÉ, D. Superoxide dismutase and stress tolerance. Annual Review of Plant Physiology and Plant Molecular Biology, Palo Alto, v. 43, p. 83116, 1992. 
BRADFORD, M.M. A rapid and sensitive method for the quantitation of microgram quantities of protein utilizing the principle of protein-dye binding. Analytical Biochemistry, New York, v. 72, p. 248-254, 1976.

BUEGE, J.A.; AUST, S.D. Microsomal lipid peroxidation. Methods Enzymology, New York, v. 52, p. 302-310, 1978.

CATANEO, A.C.; DÉSTRO, G.F.G.; FERREIRA, L.C.; CHAMMA, K.L.; SOUZA, D.C.F. Glutathione -transferase activity on the degradation of the herbicide glyphosate in maize (Zea mays) plants. Planta Daninha, Rio de Janeiro, v. 21, p. 307-312, 2003.

CATTIVELLI, L.; RIZZA, F.; BADECK, F.W.; MAZZUCOTELLI, E.; MASTRANGELO, A.M.; FRANCIA, E.; MARÉ, C.; TONDELLI, A.; STANCA, A.M. Drought tolerance improvement in crop plants: An integrated view from breeding to genomics. Field Crops Research, Amsterdam, v. 105, p. 1-14, 2008.

CIA, M.C.; GUIMARÃES, A.C.R.; MEDICI, L.O.; CHABREGAS, S.M.; AZEVEDO, R.A. Antioxidant responses to water deficit by drought-tolerant and sensitive sugarcane varieties. Annals of Applied Biology, Cambridge, v. 161, p. 313-324, 2012.

CHAVES, M.M.; MAROCO, J.P.; PEREIRA, J.S. Understanding plant responses to droughtfrom genes to the whole plant. Functional Plant Biology, Victoria, v. 30, p. 239-264, 2003.

CHEN, C.; DICKMAN, M.B. Proline suppresses apoptosis in the fungal pathogen Colletotrichum trifolii. Proceedings of the National Academy of Sciences of the USA, Washington, DC, v. 102, p. 3459-3464, 2005.

CORNIC, G. Drought stress inhibits photosynthesis by decreasing stomatal aperture not by affecting ATP synthesis. Trends in Plant Science, Kidlington, v. 5, p. 187-188, 2000.

CRUZ DE CARVALHO, M.H. Drought stress and reactive oxygen species: production, scavenging and signaling. Plant Signaling \& Behavior, Austin, v. 3, p. 156-165, 2008.

CORPAS, F.J.; SANDALIO, L.M.; PALMA, J.M.; LEIDI, E.O.; HERNANDEZ, J.A.; SEVILLA, F.; DEL RIO, L.A. Subcellular-distribution of superoxide-dismutase in leaves of ureide-producing leguminous plants. Physiologia Plantarum, Copenhagen, v. 82, p. 285$291,1991$.

DELAUNEY, A.J; VERMA, D.P.S. Proline biosynthesis and osmoregulation in plants. The Plant Journal, Oxford, v. 4, p. 215-223, 1993.

DIXON, D.P.; LAPTHORN, A.; EDWARDS, R. Plant glutathione transferases. Genome Biology, London, v. 3, p. 1-10, 2002.

DIXON, D.P.; CUMMINS L.; COLE, D.J.; EDWARDS, R. Glutathione-mediated detoxification systems in plants. Current Opinion in Plant Biology, London, v.1, p. 258266, 1998. 
EDWARDS, R.; BRAZIER-HICKS; DIXON, D.P. Cummins I. Chemical manipulation of antioxidant defences in plants. Advances in Botanical Research, London, v. 42, p.1-32, 2005.

EDWARDS, G.E.; BAKER, N.R. Can $\mathrm{CO}_{2}$ assimilation in maize leaves be predicted accurately from chlorophyll fluorescence analysis? Photosynthesis Research, Dordrecht, v. 37, p. 89-102, 1993.

ESHDAT, Y.; HOLLAND, D.; FALTIN, Z.; BEN-HAYYIM, G. Plant glutathione peroxidases. Physiologia Plantarum, Copenhagen, v. 100, p. 234-240, 1997.

FAN, L.; LINKER, R.; GEPSTEIN, S.; TANIMOTO, E.; YAMAMOTO, R.; NEUMANN, P.M. Progressive Inhibition by Water Deficit of Cell Wall Extensibility and Growth along the Elongation Zone of Maize Roots Is Related to Increased Lignin Metabolism and Progressive Stelar Accumulation of Wall Phenolics. Plant Physiology, Rockville, v. 140, p. 603-612, 2006.

FERREIRA, R.R.; FORNAZIER, R.F.; VITÓRIA, A.P.; LEA, P.J.; AZEVEDO, R.A. Changes in antioxidant enzyme activities in soybean under cadmium stress. Journal of Plant Nutrition, New York, v. 25, p. 327-342, 2002.

FORNAZIER, R.F.; FERREIRA, R.R.; VITÓRIA, A.P.; MOLINA, S.M.G.; LEA, P.J.; AZEVEDO, R.A. Effects of cadmium on antioxidant enzyme activities in sugarcane. Biologia Plantarum, Praha, v. 45, p. 91-97, 2002a.

FORNAZIER, R.F.; FERREIRA, R.R.; PEREIRA, G.J.G.; MOLINA, S.M.G.; SMITH, R.J.; LEA, P.J.; AZEVEDO, R.A. Cadmium stress in sugar cane callus cultures: Effect on antioxidant enzymes. Plant Cell, Tissue and Organ Culture, Dordrecht, v. 71, p. 125-131, $2002 b$.

FOYER, C.; NOCTOR, G. Redox regulation in photosynthetic organisms: signaling, acclimation and practical implications. Antioxidants \& Redox Signal, New Rochelle, v. 11, p. 1-45, 2009.

FOYER, C.H.; LOPEZ-DELGADO, H.; DAT, J.F.; SCOTT, I.M. Hydrogen peroxide and glutathione-associated mechanism of acclimatory stress tolerance and signalling. Physiologia Plantarum, Copenhagen, v. 100, p. 241-254, 1997.

FRITSCHE-NETO, R.; DOVALE, J.C.; CAVATTE, P.C. Melhoramento para tolerância a estresses ou para eficiência no uso de recursos? In: FRITSCHE-NETO, R.; BORÉM, A. (Ed.). Melhoramento de plantas para condições de estresses abióticos. Visconde de Rio Branco: Suprema, 2011. p. 29-38.

FRUGOLI, J.A.; ZHONG, H.H.; NUCCIO, M.L.; MCCOURT, P.; MCPEEK, M.A.; THOMAS, T.L.; MCCLUNG, C.R. Catalase is encoded by a multigene family in Arabidopsis thaliana (L.). Plant Physiology, Rockville, v. 112, p. 327-336, 1996.

FUMIS, T. de F.; PEDRAS, J.F. Variação nos níveis de prolina, diamina e poliaminas em cultivares de trigo submetido a déficits hídricos. Pesquisa Agropecuária Brasileira, Brasilia, DF, v. 37, p. 449-453, 2002. 
GIANNOPOLITIS, C.N.; RIES, S.K. Superoxide dismutases in higher plants. Plant Physiology, Rockville, v. 59, p. 309-314, 1977.

GILL, S.S.; TUTEJA, N. Reactive oxygen species and antioxidant machinery in abiotic stress tolerance in crop plants. Plant Physiology and Biochemistry, Paris, v. 48, p. 909-930, 2010.

GRATÃO, P.L.; POLLE, A.; LEA, P.J.; AZEVEDO, R.A. Making the life of heavy metalstressed plants a little easier. Functional Plant Biology, Victoria, v. 32, p. 481-494, 2005.

GÓMEZ-CARAVACA, A.M.; IAFELICE, G.; LAVINI, A.; PULVENTO, C.; CABONI, M.F.; MARCONI, E. Phenolic compounds and saponins in quinoa samples (Chenopodium quinoa Willd.) grown under different saline and nonsaline irrigation regimens. Journal of Agricultural and Food Chemistry, Easton, v. 60, p. 4620-4627, 2012.

HABIG, W.H.; JAKOBY, W.B. Assays for determination of glutathione S-transferase. Methods in Enzymology, New York, v. 77, p. 398-405, 1981.

HOLTMAN, W.L.; HEISTEK, J.C.; MATTERN, K.A.; BAKHUIZEN, R.; DOUMA, A.C. Beta-oxidation of fatty acids is linked to the glyoxylate cycle in the aleurone but not in the embryo of germinating barley. Plant Science, Amsterdam, v. 99, p. 43-53, 1994.

IGAMBERDIEV, A.U.; LEA, P.J. The role of peroxisomes in the integration of metabolism and evolutionary diversity of photosynthetic organisms. Phytochemistry, Oxford, v. 60, p. 651-674, 2002.

ILANGOVAN, G.; VENKATAKRISHNAN, C.D.; BRATASZ, A.; OSINBOWALE, S.; CARDOUNEL, A.J.; ZWEIER, J.L.; KUPPUSAMY, P. Heat shock-induced attenuation of hydroxyl radical generation and mitochondrial aconitase activity in cardiac H9c2 cells. American Journal of Physiology - Cell Physiology, Bethesda, v. 290, C313-324, 2006.

INMAN-BAMBER, N.G.; BONNETT, G.D.; SMITH, D.M.; THORBURN, P.J. Sugarcane physiology: Integration from cell to crop to advance sugarcane production. Field Crops Research, Amsterdam, v. 92, p. 115-117, 2005.

ISKANDAR, H.; SIMPSON, R.; CASU, R.; BONNETT, G.; MACLEAN, D.; MANNERS, J. Comparison of reference genes for quantitative real-time polymerase chain reaction analysis of gene expression in sugarcane. Plant Molecular Biology Reporter New York, v. 22, p. 325-337, 2004.

KLIEBENSTEIN, D.J.; MONDE, R.A.; LAST, R.L. Superoxide dismutase in Arabidopsis: An acletic enzyme family with disparate regulation and protein localization. Plant Physiology, Rockville, v. 118, p. 637-650, 1998.

KONRAD, M.L.F.; SILVA, J.A.B.; FURLANI, P.R.; MACHADO, E.C. Trocas gasosas e fluorescência da clorofila em seis cultivares de cafeeiro sob estresse de alumínio. Bragantia, Campinas, v. 64, p. 339-347, 2005.

KRAUSE, G.H.; WEIS, E. Chlorophyll fluorescence and photosynthesis: the basics. Annual Review Plant Physiology and Plant Molecular Biology, Palo Alto, v. 42, p. 313-349, 1991. 
KWON, S.Y.; JEONG, Y.J.; LEE, H.S.; KIM, J.S.; CHO, K.Y.; ALLEN, R.D.; KWAK, S.S. Enhanced tolerances of transgenic tobacco plants expressing both superoxide dismutase and ascorbate peroxidase in chloroplasts against methyl viologen-mediated oxidative stress. Plant, Cell \& Environment, Nottingham, v. 25, p. 873-882, 2002.

LASCANO, H.R.; ANTONICELLI, G.E.; LUNA, C.M.; MELCHIORRE, M.N.; GÓMEZ, L.D.; RACCA, R.W.; TRIPPI, V.S.; CASANO, L.M. Antioxidant system response of different wheat cultivars under drought: field and in vitro studies. Australian Journal of Plant Physiology, Melbourne, v. 28, p. 1095-1102, 2001.

LAWLOR, D.W.; CORNIC, G. Photosynthetic carbon assimilation and associated metabolism in relation to water deficits in higher plants. Plant, Cell \& Environment, Nottingham, v. 25, p. 275-94, 2002.

LEAL, J.R.G.A.; ALBUQUERQUE, P.S.B.; FIGUEIRA, A. Genes differentially expressed in Theobroma cacao associated with resistance to witches' broom disease caused by Crinipellis perniciosa. Molecular Plant Pathology, Oxford, v. 8, p. 279-292, 2007.

LEE, D.H.; LEE, C.B. Chilling stress-induced changes of antioxidant enzymes in the leaves of cucumber; in gel enzyme activity assays. Plant Science, Amsterdam, v. 159, p. 75-85, 2000 .

LEÓN, A.M.; PALMA, J.M.; CORPAS, F.J.; GOMEZ, M.; ROMERO-PUERTAS, M.C.; CHATTERJEE, D.; MATEOS, R.M.; DEL RIO, L.A.; SANDALIO, L.M. Antioxidative enzimes in cultivars of peppers plants with different sensitivity to cadmium. Plant Physiology and Biochemistry, Paris, v. 40, p. 813-820, 2002.

LEVITT, J. Responses of plants to environmental stress: chilling, freezing and high temperature stresses. New York: Academic Press, 1980.

LÓPEZ-VÉLEZ, M.; MARTÍNEZ-MARTÍNEZ, F.; DEL VALLE-RIBES, C. The study of phenolic compounds as natural antioxidants in wine. Critical Reviews in Food Science and Nutrition, London, v. 43, p. 233-244, 2003.

LU, Y.; DENG, X.; KWAK, S. Over expression of CuZn superoxide dismutase (CuZnSOD) and ascorbate peroxidase (APX) in transgenic sweet potato enhances tolerance and recovery from drought stress. African Journal of Biotechnology, Victoria Island, Lagos, v. 9, p. 83788391, 2010.

MAEVSKAYA, S.N.; NIKOLAEVA, M.K. Response of Antioxidant and Osmoprotective Systems of Wheat Seedlings to Drought and Rehydration. Russian Journal of Plant Physiology, New York, v. 60, p. 343-350, 2013.

MAKKAR, H.P.S.; BLUMMEL M.; BOROWY, N.K.; BECKER, K. Gravimetric determination of tannins and their correlation with chemical and protein precipitation methods. Journal of the Science of Food and Agriculture, London, v. 61, p. 161-165, 1993.

MALLICK, N.; MOHN, F.H. Reactive oxygen species: response of alga cells. Journal of Plant Physiology, Stuttgart, v. 157, p. 183-193, 2000. 
MARRS, K.A. The functions and regulation of glutathione S-transferases in plants. Annual Review of Plant Physiology and Plant Molecular Biology, Palo Alto, v. 47, p. 127-158, 1996.

MAXWELL, K.; JOHNSON, G.N. Chlorophyll fluorescence - a practical guide. Journal of Experimental Botany, Oxford, v. 51, p. 659-668, 2000.

MITTLER, R. Oxidative stress, antioxidant and stress tolerance. Trends in Plant Science, Kidlington, v. 7, p. 405-410, 2002.

MOLINARI, H.B.C.; MARUR, C.J.; DAROS, E.; CAMPOS, M.K.F.; CARVALHO, J.F.R.P.; BESPALHOK-FILHO, J.C.; PEREIRA, L.F.P.; VIEIRA, L.G.E. Evaluation of the stress-induce production of proline in transgenic sugarcane (Saccharum spp.): osmotic adjustment, chlorophyll fluorescence and oxidative stress. Physiologia Plantarum, Copenhagen, v. 130, p. 218-229, 2007.

MOLLER, I.M. Plant mitochondria and oxidative stress: electron transport, NADPH turnover, and metabolism of reactive oxygen species. Annual Review of Plant Physiology and Plant Molecular Biology, Palo Alto, v. 52, p. 561-591, 2001.

MONTAVON, P.; KUKIC, K.R.; BORTILIK, K. A simple method to measure effective catalase activities: Optimization, validation, and application in green coffee. Analytical Biochemistry, New York, v. 360, p. 207-215, 2007.

MULLET, J.E.; WHITSITT, M.S. Plant cellular responses to water deficit. Plant Growth Regulation, Dordrecht, v. 20, p. 119-124, 1996.

MULLINEAUX, P.M.; CREISSEN, G.P. Glutathione reductase: regulation and role in oxidative stress. In: SCANDALIOS, J.C. (Ed.). Oxidative stress and the molecular biology of antioxidant defenses. Cold Spring Harbor: Cold Spring Harbor Laboratory Press, 1997. p. 667-713.

NAKANO, Y.; ASADA, K. Hydrogen peroxide is scavenged by ascobate specific peroxidase in spinach cloroplasts. Plant and Cell Physiology, Tokyo, v. 22, p. 867-880, 1981.

NANJO, T.; KOBAYASHI, M.; YOSHIBA, Y.; SANADA, Y.; WADA, K.; TSUKAYA, H.; KAKUBARI, Y.; YAMAGUCHI-SHINOZAKI, K.; SHINOZAKI, K. Biological functions of proline in morphogenesis and osmotolerance revealed in antisense transgenic Arabidopsis thaliana. Plant Journal, Oxford, v. 18, p.185-193, 1999.

NISHIMURA, D. S. Caracterização molecular da glutationa S-transferase de cana-deaçúcar (Saccharum spp.) em resposta a aplicação de herbicidas. 2007. 113 p. Dissertação (Mestrado em Ciências) - Centro de Energia Nuclear na Agricultura, Universidade de São Paulo, Piracicaba, 2007.

NOCTOR, G.; GOMEZ, L.; VANACKER, H.; FOYER, C.H. Interactions between biosynthesis, compartmentation and transport in the control of gluthatione homeostasis and signalling. Journal of Experimental Botany, Oxford, v. 53, p. 1283-1304. 2002. 
NOCTOR, G.; FOYER, C.H. Ascorbate and glutathione: keeping active oxygen under control. Annual Review of Plant Physiology and Plant Molecular Biology, Palo Alto, v.49, p.249-279, 1998.

OLIVEIRA, J.F.N.C. Caracterização fisiológica e perfil de expressão gênica de cultivares de cana-de-açúcar (Saccharum spp) contrastantes para o deficit hídrico. 2012. 327 p. Tese (Doutorado em Ciências) - Escola Superior de Agricultura "Luiz de Queiroz", Universidade de São Paulo, Piracicaba, 2012.

OLMOS, E.; MARTINEZ-SOLANO, J.R.; PIQUERAS, A.; HELLIN, E. Early steps in the oxidative burst induced by cadmium in cultured tobacco cells (BY-2 line). Journal of Experimental Botany, Oxford, v. 54, p. 291-301, 2003.

OSMOND, B.; SCHWARTZ, O.; GUNNING, B. Photoinhibitory printing on leaves, visualized by chlorophyll fluorescence imaging and confocal microscopy, is due to the diminished fluorescence from grana. Australian Journal of Plant Physiology, Melbourne, v. 26, p. 171-724, 1999.

PAN, S.; YAU, Y. The isozymes of superoxide dismutase in rice. Botanical Bulletin of Academia Sinica, Taipei, v. 32, p. 253-258, 1991.

PELTZER, D.; DREYER, E.; POLLE, A. Temperature dependencies of antioxidative enzymes in two contrasting species. Plant Physiology and Biochemistry, Paris, v. 40, p. 141-50, 2002.

PFAFFL, M.W.; HORGAN, G.W.; DEMPFLE, L. Relative expression software tool (REST) for groupwise comparison and statistical analysis of relative expression results in real-time PCR. Nucleic Acids Research, London, v. 30, p. e36, 2002.

PINTO, M.C.D.; TOMMASI, F.; GARA, L.D. Enzymes of the ascorbate biosynthesis and ascorbate-glutathione cycle in cultured cells of tobacco Bright Yellow 2. Plant Physiology and Biochemistry, Paris, v. 38, p. 541-550, 2000.

QUEIROZ, R.J.B.; SANTOS, D.M.M.; CARLIN, S.D.; MARIN, A.; BANZATTO, D.A.; CAZETTA, J.O. Osmoprotetores em cana-de-açúcar sob efeito da disponibilidade hídrica do solo. Científica, Jaboticabal, v. 36, p. 107-115, 2008.

REDDY, A.R.; CHAITANYA, K.V.; VIVEKANANDAN, M. Drought-induced responses of photosynthesis and antioxidant metabolism in higher plants. Journal of Plant Physiology, Stuttgart, v. 161, p. 1189-1202, 2004.

RIBEIRO, R.V.; MACHADO, R.S.; MACHADO, E.C.; MACHADO, D.F.S.P.; MAGALHÃES FILHO, J.R.; LANDELL, M.G.A. Revealing drought-resistance and productive patterns in sugarcane genotypes by evaluating both physiological responses and stalk yield. Experimental Agriculture, London, v. 49, p. 212-224, 2013.

SABEH, F.; WRIGHT, T.; NORTON, S.J. Purification and characterization of a glutathione peroxidase from the Aloe vera plant. Enzyme \& Protein, Basel, v. 47, p.92-98, 1993. 
SCANDALIOS, J.G. Oxidative stress: molecular perception and transduction of signals triggering antioxidant gene defenses. Brazilian Journal of Medical and Biological Research, Ribeirão Preto, v. 38, p. 995-1014, 2005.

SCANDALIOS, J.G.; ACEVEDO, A.; RUZSA, S. Catalase gene expression in response to chronic high temperature stress in maize. Plant Science, Amsterdam, v. 156, p. 103-110, 2000 .

SCHELLER, H.V.; HALDRUP, A. Photoinhibition of photosystem I. Planta, Berlin, v. 221, p. 5-8, 2005.

SEHMER, L.; DIZENGREMEL, P. Contribution to subcellular localization of superoxide dismutase isoforms of spruce needles and oak leaves. Journal of Plant Physiology, Stuttgart, v. 53, p. 545-551, 1998.

SKADSEN, R.W.; SCHULZE-LEFERT, P.; HEBERST, J.M. Molecular cloning, characterization and expression of two catalase isozyme genes in barley. Plant Molecular Biology, Dordrecht, v. 29, p. 1005-1014, 1995.

SODEK, L. Metabolismo do nitrogênio. In: KERBAUY, G. B. (Ed.). Fisiologia vegetal. Rio de Janeiro: Guanabara Koogan, 2004. cap. 4, p. 94-113.

TAIZ, L.; ZEIGER, E. Fisiologia vegetal. Porto Alegre: Artmed, 2009. 819 p.

TATAR, O.; GEVREK, M.N. Influence of water stress on proline accumulation, lipid peroxidation and water content of wheat. Asian Journal of Plant Sciences, New York, v. 7, p. 409-412, 2008.

VAN CAMP, W.; CAPIAU, K.; VAN MONTAGU, M.; INZÉ, D.; SLOOTEN, L. Enhancement of oxidative stress tolerance in transgenic tobacco plants overproducing $\mathrm{Fe}$ superoxide dismutase in chloroplasts. Plant Physiology, Rockville, v. 112, p. 1703-14, 1996.

VAN DILLEWIJN, C. Botany of sugarcane. Walthham: Chronica Botanica, 1952. 371 p.

VAN KOOTEN, O.; SNEL, J.F.H. The use of chlorophyll fluorescence nomenclature in plant stress physiology. Photosynthesis Research, Dordrecht, v. 25, p. 147-150, 1990.

VRANOVA, E.; ATICHARTPONGKUL, S.; VILLARROEL, R.; MONTAGU, M.V.; INZÉ, D.; CAMP, W.V. Comprehensive analysis of gene expression in Nicotiana tabacum leaves acclimated to oxidative stress. Proceedings of the National Academy of Sciences of the USA, Washington, DC, v. 99, p. 870-875, 2002.

WANG, F.Z.; WANG, Q.B.; KWON, S.Y.; KWAK, S.S.; SU, W.A. Enhanced drought tolerance of transgenic rice plants expressing a pea manganese superoxide. Journal of Plant Physiology, Stuttgart, v. 162, p. 465-72, 2005.

WOODBURY, W.; SPENCER, A.K.; STAHMAN, M.A. Improved procedure using ferricyanide for detecting catalase isozymes. Analytical Biochemistry, New York, v. 44, p. 301-305, 1971. 
WU, J.; OMOKAWA, H.; HATZIOS, K.K. Glutathione S-transferase activity in unsafened and fenclorim-safened rice (Oryza sativa). Pesticide Biochemistry and Physiology, New York, v. 54, p. 220-229, 1996.

YU, B.P. Cellular defenses against damage from reactive oxygen species. Physiological Reviews, Washington, DC, v. 74, p. 139-162, 1994. 